\title{
ANÁLISE PROTEÔMICA DE Synechococcus leopoliensis PCC7942 EM RESPOSTA AO CÁDMIO
}

\author{
YASMIN GRUMMT NADDAF
}

Dissertação apresentada à Escola Superior de Agricultura "Luiz de Queiroz", Universidade de São Paulo, para obtenção do título de Mestre em Agronomia, Área de Concentração: Microbiologia Agrícola.

PIRACICABA

Estado de São Paulo - Brasil

Junho - 2004 


\title{
ANÁLISE PROTEÔMICA DE Synechococcus leopoliensis PCC7942 EM RESPOSTA AO CÁDMIO
}

\author{
YASMIN GRUMMT NADDAF \\ Licenciado e Bacharel em Ciências Biológicas
}

Orientadora: Profa. Dra. MARLI DE FÁTIMA FIORE

Dissertação apresentada à Escola Superior de Agricultura "Luiz de Queiroz", Universidade de São Paulo, para obtenção do título de Mestre em Agronomia, Área de Concentração: Microbiologia Agrícola.

\author{
PIR A CICAB A \\ Estado de São Paulo - Brasil \\ Junho - 2004
}




\section{Dados Internacionais de Catalogação na Publicação (CIP) DIVISÃO DE BIBLIOTECA E DOCUMENTAÇÃO - ESALQ/USP}

\section{Naddaf, Yasmin Grummt}

Análise proteômica de Synechococcus leopoliensis PCC7942 em resposta ao cádmio / Yasmin Grummt Naddaf. - Piracicaba, 2004.

89 p. : il.

Dissertação (mestrado) - - Escola Superior de Agricultura Luiz de Queiroz, 2004.

Bibliografia.

1. Cádmio 2. Cianobactéria 3. Eletroforese 4. Espectrometria de massas 5. Proteína Título

CDD 589.46

"Permitida a cópia total ou parcial deste documento, desde que citada a fonte - O autor" 
À minha família,

por todo o apoio, amor e compreensão,

dedico 


\section{AGRADECIMENTOS}

À Profa. Dra. Marli de Fátima Fiore pela orientação, apoio e amizade em todos os momentos;

À Dra. Cláudia de Mattos Bellato (CENA-USP) pela colaboração no trabalho com eletroforese bi-dimensional e pelas sugestões ;

Ao Prof. Dr. Marcos N. Eberlin e Dr. Demian R. Ifa (IQ-UNICAMP) pela colaboração na identificação das proteínas por MALDI-TOF-MS;

À M.Sc. Adriana F. Paes-Leme pela colaboração na metodologia de digestão de proteínas in gel e pelas sugestões;

Ao Prof. Dr. Francisco Krug e Dr. Fernando Barbosa Jr. (CENA-USP) pela colaboração nas análises de metais por Espectrometria de Absorção Atômica;

Ao Prof. Dr. Arnaldo Rodella (ESALQ-USP) e ao Prof. Dr. Luiz R. G. Guimarães (UFLA) pelo auxílio na utilização do programa MINTEQ;

À Profa. Dra. Siu Mui Tsai (CENA-USP) pelo apoio concedido;

Ao Diego B. Genuário e Vítor A. C. Pavinato, alunos de graduação em Ciências Biológicas (ESALQ), por todo apoio nos trabalhos de laboratório;

A todos os colegas e funcionários do Laboratório de Biologia Celular e Molecular (CENA-USP) pelo ótimo convívio e pelo auxílio neste trabalho;

À FAPESP, pelo auxílio financeiro no projeto;

À CAPES, pela bolsa de estudo concedida. 


\section{SUMÁRIO}

Página

RESUMO .................................................................... viii

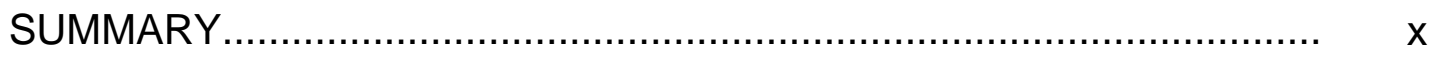

1 INTRODUÇÃO ................................................................... 1

2 REVISÃO DE LITERATURA .................................................. 4

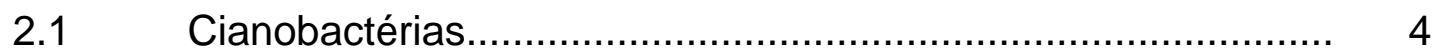

2.1.1 Aspectos gerais...................................................... 4

2.1.2 História evolutiva e ambientes adversos............................ 5

2.1.3 Synechococcus leopoliensis PCC7942...................... 5

2.2 Cianobactérias como modelo para estudos genéticos, bioquímicos e fisiológicos............................................ 6

2.3 Estudos proteômicos em cianobactérias............................ 7

2.4 Estudos de expressão diferencial de genes de cianobactérias em situações de estresse ............................................... 9

2.4.1 Respostas à escassez de nutrientes e diferentes intensidades luminosas............................................................. 9

2.4.2 Respostas a altas temperaturas....................................... 10

2.4.3 Respostas a metais pesados......................................... 11

2.5 Efeitos tóxicos de metais pesados em cianobactérias e mecanismos de tolerância........................................... 12

$2.6 \quad$ Biotecnologia ambiental......................................... 14

3 MATERIAL E MÉTODOS..................................................... 16

3.1 Cultivo da cianobactéria........................................... 16

3.2 Reagentes químicos utilizados........................................ 16

3.3 Curva de crescimento da cianobactéria............................... 16 
3.4 Determinação da dose máxima de Cd tolerável pela Synechococcus leopoliensis PCC7942 e curva de crescimento da cianobactéria na presença de cádmio

3.5 Curvas de crescimento de culturas na presença da máxima concentração tolerável de cádmio e acúmulo do metal pelas células.

3.6 Especiação do $\mathrm{CdCl}_{2}$ no meio de cultura BG-11................... 20

3.7 Estudo comparativo de proteomas de Synechococcus leopoliensis PCC 7942 em resposta ao cádmio................... 21

3.7.1 Reagentes químicos utilizados...................................... 21

3.7.2 Cultivo da cianobactéria e adição do cádmio......................... 21

3.7.3 Extração e quantificação de proteínas..................................... 22

3.7.4 Eletroforese bi-dimensional.......................................... 23

3.7.4.1 Focalização isoelétrica (primeira-dimensão)......................... 23

3.7.4.2 Equilíbrio da fita........................................................ 24

3.7.4.3 Eletroforese em gel de poliacrilamida desnaturante (segunda-

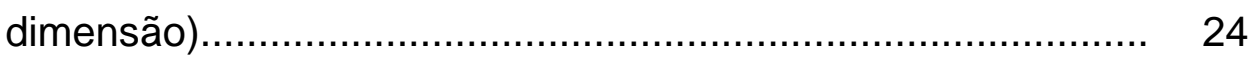

3.7.5 Detecção das proteínas contidas no géis de poliacrilamida..... 25

3.7.6 Análise das proteínas contidas nos géis de poliacrilamida...... 25

3.7.7 Identificação das proteínas expressas diferencialmente.......... 26

3.7.7.1 Digestão das proteínas para análise com MALDI-TOF-MS..... 26

3.7.7.2 Identificação das proteínas por MALDI-TOF-MS.................... 27

3.7.7.3 Identificação das proteínas em banco de dados.................... 28

4 RESULTADOS E DISCUSSÃO............................................. 29

$4.1 \quad$ Curva de crescimento da cianobactéria............................... 29

4.2 Avaliações para determinação da dose máxima de Cd tolerável pela Synechococcus leopoliensis PCC7942 e Curva de crescimento da cianobactéria na presença de cádmio. 
4.3 Curvas de crescimento de culturas na presença da máxima concentração tolerável de cádmio e acúmulo do metal pelas células

$4.4 \quad$ Especiação do cádmio em meio BG-11........................... 39

4.5 Análise da expressão diferencial de proteínas da cianobactéria na presença de cádmio através de gel bi-dimensional

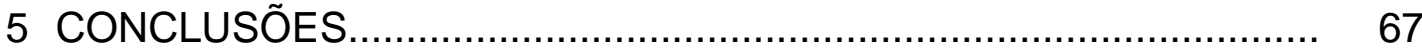

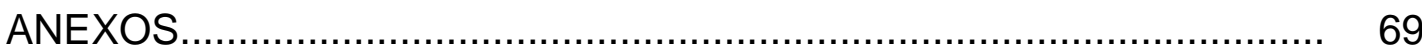

REFERÊNCIAS BIBLIOGRÁFICAS ............................................. 75 


\title{
ANÁLISE PROTEÔMICA DE Synechococcus leopoliensis PCC7942 EM RESPOSTA AO CÁDMIO
}

\author{
Autora: YASMIN GRUMMT NADDAF \\ Orientadora: Profa. Dra. MARLI DE FÁTIMA FIORE
}

\section{RESUMO}

As cianobactérias são procariotos fotossintetizantes capazes de sobreviver em ambientes com condições adversas, inclusive na presença de metais pesados tal como o cádmio ( $\mathrm{Cd}$ ). Alguns mecanismos celulares de tolerância a metais pesados são o efluxo de íons e destoxificação intracelular. A proteína metalotioneína, a qual foi purificada e seqüenciada na cianobactéria Synechococcus sp. PCC7942, possui a capacidade de quelar alguns metais. A análise do produto gênico (RNAm e/ou proteínas) têm trazido informações interessantes sobre o metabolismo de células submetidas a situações estresse. Esse estudo teve como objetivo analisar as respostas das células da cianobactéria Synechococcus leopoliensis PCC7942 ao Cd. Para isto, foi analisado o padrão de crescimento das culturas, o acúmulo de $\mathrm{Cd}$ e a expressão de proteínas da cianobactéria na presença do metal. A concentração máxima de Cd tolerável pela cianobactéria de $3 \mu \mathrm{M}$ foi determinada através do monitoramento do crescimento de culturas submetidas a diferentes concentrações do metal através da análise de $\mathrm{DO}_{750 \mathrm{~nm}}$. As culturas crescidas nessa concentração do $\mathrm{Cd}$ apresentaram um prolongamento na fase de 
adaptação e maior tempo de duplicação comparando-se as culturas controles (sem metal). O cádmio acumulado pelas células analisado usando GFAAS

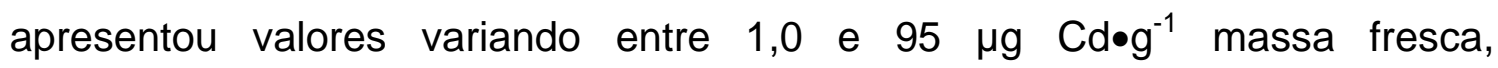
dependendo da fase de crescimento. $\mathrm{A}$ análise da especiação do $\mathrm{Cd}$ no meio de cultura BG-11 mostrou que havia disponível para as células $0,69 \mu \mathrm{M}$ de $\mathrm{Cd}^{+2}$ quanto se utilizava a quantidade máxima tolerável (3 $\mu \mathrm{M})$. A análise de expressão diferencial de proteínas foi feita em culturas expostas a duas concentrações do metal, $3 \mu \mathrm{M}$ (tolerável) e $100 \mu \mathrm{M}$ (letal), durante 1 hora, as

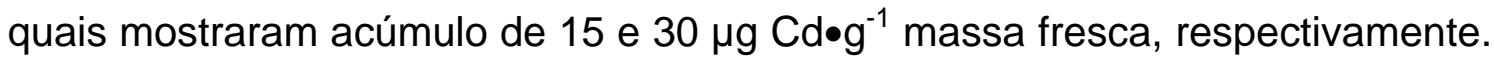
A maioria das proteínas da cianobactéria separadas por eletroforese bidimensional ( $\mathrm{pH}$ 3-10 e 4,5-5,5) mostrou pontos isoelétricos ácidos, entre a faixa de $\mathrm{pH} 4$ e 6 , e a presença de várias isoformas. Trinta proteínas foram expressas diferencialmente, sendo que no tratamento com $3 \mu \mathrm{M}$ de $\mathrm{Cd}$, duas proteínas foram induzidas e 11 reprimidas, e no tratamento com $100 \mu \mathrm{M}$, duas proteínas foram induzidas e 20 reprimidas. Entre as proteínas reprimidas, duas foram comuns em ambos os tratamentos, enquanto que as duas proteínas induzidas em cada tratamento foram diferentes. Algumas dessas proteínas identificadas através de MALDI-TOF foram a rubisco, a qual foi reprimida em 3 $\mu \mathrm{M}$ de Cd; uma proteína da capa do carboxissoma, a qual foi induzida na presença de $100 \mu \mathrm{M}$ de Cd; a proteína ligadora a DNA (Dpsa) e a isoleucil tRNA sintetase, ambas induzidas em $3 \mu \mathrm{M}$ de Cd e reprimidas em $100 \mu \mathrm{M}$ de Cd. Dessa forma, esses dados mostraram que duas das proteínas afetadas pelo Cd são componentes do sistema fotossintetizante (rubisco e capa protéica do carboxissoma), uma é expressa em condições de estresse oxidativo (Dpsa) e a outra está relacionada com a síntese de proteínas contendo isoleucina (isoleucil-tRNA sintetase). 


\title{
PROTEOMIC ANALYSIS OF Synechococcus leopoliensis PCC7942 IN RESPONSE TO CADMIUM
}

\author{
Author: YASMIN GRUMMT NADDAF \\ Adviser: Prof. Dr. MARLI DE FÁTIMA FIORE
}

\section{ABSTRACT}

Cyanobacteria are photosynthetic prokaryotes capable of surviving in adverse environmental conditions, including the presence of heavy metals such as cadmium (Cd). Some cellular mechanisms of heavy metal tolerance are ion efflux and intracellular detoxification. The metallothionein protein, which was purified and sequenced in the cyanobacterium Synechococcus sp. PCC7942, possesses the ability to bind some metals. The analysis of gene products (mRNA and/or proteins) has provided interesting information about cell metabolism under stress conditions. The aim of this study was to analyze the $\mathrm{Cd}$ response of the cyanobacterium S. leooliensis PCC7942 cells. For this purpose, the pattern of culture growth, cadmium accumulation, and cyanobacterial protein expression in the presence of the metal was analyzed. The maximum tolerable Cd concentration of $3 \mu \mathrm{M}$ by the cyanobacterium was determined by monitoring culture growth submitted to different concentrations of the metal using $O D_{750 \mathrm{~nm}}$ analysis. The cultures grown in this $\mathrm{Cd}$ concentration had an extended lag phase and a higher doubling time compared to the control cultures (without metal). Cadmium accumulated by the cells analyzed using GFAAS showed 


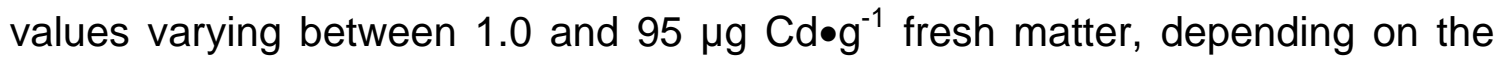
growth phase. Speciation analysis of $\mathrm{Cd}$ in the growth medium BG-11 showed that $0.69 \mu \mathrm{M}$ of $\mathrm{Cd}^{2+}$ was available to the cells when the maximum tolerable amount was used $(3 \mu \mathrm{M})$. Analysis of the proteins with differential expression was done using cultures exposed for 1 hour to two metal concentrations, $3 \mu \mathrm{M}$ (non-lethal) and $100 \mu \mathrm{M}$ (lethal), which showed accumulation of 15 and $30 \mu \mathrm{g}$ $\mathrm{Cd} \mathrm{g}^{-1}$ fresh matter, respectively. The majority of the cyanobacterial proteins separated by two-dimensional electrophoresis ( $\mathrm{pH} 3-10$ and 4,5-5,5) showed $\mathrm{p} /$ between $\mathrm{pH} 4$ and 6 , and the presence of several isoforms. Thirty proteins were differentially expressed, where two proteins were up-regulated and 11 downregulated in the treatment with $3 \mu \mathrm{M}$ of $\mathrm{Cd}$ and two proteins were up-regulated and 20 down-regulated in the treatment with $100 \mu \mathrm{M}$ of $\mathrm{Cd}$. Among the downregulated proteins, two were common in both treatments while the two upregulated proteins from each treatment were different. Some of the proteins identified by MALDI-TOF were rubisco, which was down-regulated in $3 \mu \mathrm{M}$ of $\mathrm{Cd}$; a carboxysome shell protein, which was up-regulated in100 $\mu \mathrm{M}$ of $\mathrm{Cd}$; the DNA-binding protein, Dpsa, and a isoleucyl-tRNA sinthetase, both up-regulated in $3 \mu \mathrm{M}$ of $\mathrm{Cd}$ and down-regulated in $100 \mu \mathrm{M}$ of $\mathrm{Cd}$. Thus, these data showed that the two proteins affected by $\mathrm{Cd}$ are components of the photosynthetic system (rubisco and carboxysome shell protein), one is expressed under oxidative stress condition (Dpsa) and the other one is related to protein synthesis containing isoleucine (isoleucyl-tRNA sinthetase). 


\section{INTRODUÇÃO}

As cianobactérias são procariotos fotossintetizantes capazes de sintetizar clorofila a e ficobilinas (pigmentos que ajudam na captura de luz e participam da fotossíntese). Esse grupo de microrganismos tem uma longa história evolutiva, sendo que os seus ancestrais foram os responsáveis pela mudança nas condições da Terra de um ambiente anóxico para uma atmosfera com oxigênio. As cianobactérias ocorrem em diverso habitat e são capazes de sobreviver em situações adversas, incluindo ambientes salinos, altas temperaturas, alta radiação de ultravioleta, ambientes com escassez de nutrientes e presença de metais pesados (Stal, 2000; Castenholz \& Garcia Pichel, 2000; Castenholz \& Waterbury, 1989; Bauld, 1981; Whitton, 1991). Várias espécies de ianobactérias têm sido encontradas em ambientes contaminados com metais pesados (Fiore et al., 1998). (Robinson et al., 2000) sugere que o surgimento do oxigênio na Terra, presenciado pelos ancestrais das cianobactérias atuais, tenha provocado uma mudança na composição de metais da Terra e que isso teria influenciado no desenvolvimento de mecanismos de tolerância de cianobactérias a metais pesados. Entre os mecanismos de tolerância relacionada à indução da expressão gênica está a exclusão do metal da célula pela ação de transportadores na membrana e na captura e armazenamento intracelular do metal em componentes específicos da célula (Fiore et al., 1998). Na cianobactéria Synechococcus sp. PCC7942, um mecanismo de destoxificação interna de metal bem descrito é a expressão da proteína metalotioneína. Esta proteína é rica em cisteína, a qual possui sítios de ligação para metais nos seus grupos sulfidrílicos. $O$ estudo de expressão gênica 
em cianobactéria tem sido facilitado pelas informações originadas do sequenciamento de genomas de algumas espécies, tais como a Synechocistis sp. PCC6803 (Kaneko et al., 1995) e a Thermosynechoccous elongatus (Nakamura et al., 2002). Além da capacidade de transformação genética identificada de ambas espécies (Grigorieva \& Shestakov, 1982; Iwai et al., 2004; Onai et al., 2004).

Estudos realizados até agora com mutantes e com produtos de expressão gênica dessas cianobactérias têm como enfoque principal a compreensão dos mecanismos envolvidos na fotossíntese (Kotani \& Tabata, 1998). Os mecanismos moleculares e bioquímicos de tolerância a metais têm sido estudados em menor escala e ainda são poucas as informações disponíveis. Existe, portanto, necessidade de mais estudos sobre a capacidade de distinção entre respostas metabólicas que ocorrem em resposta a estímulos gerais, como temperatura e escassez de nutrientes e respostas provocadas por estímulos específicos, nesse caso, pelo metal. Uma das possíveis aplicações para essas informações está na biotecnologia ambiental. O entendimento dos mecanismos de toxicidade de metal sobre a célula assim como os mecanismos de tolerância podem auxiliar na manipulação de organismos utilizados para a limpeza de áreas naturais contaminadas por metais através de sua capacidade de acúmulo. Em muitos casos a atividade biodegradadora de algumas bactérias é inibida pela presença de metais, e a capacidade de tolerância por esses metais é importante. Outra aplicação que está sendo formulada é a construção de biosensores (Bontidean et al., 2000; Rouillon et al., 1999), onde no caso da Synechococus sp. PCC7942 constrói-se marcadores que são ativados quimicamente quando o gene da metalotioneína é transcrito na presença do metal. 
O objetivo do presente estudo foi obter informações referentes às proteínas da cianobactéria Synechococcus leopoliensis PCC7942 que tem sua expressão afetada (induzidas ou reprimidas) pela presença do metal cádmio. Estudos de tolerância das células dessa cianobactéria ao cádmio também foram realizados visando conhecer as concentrações tóxicas deste metal para as células deste organismo. 


\section{REVISÃO DE LITERATURA}

\subsection{Cianobactérias}

\subsubsection{Aspectos gerais}

As cianobactérias constituem o grupo maior, mais diverso, e mais amplamente distribuído de procariotos fotossintetizantes (Stanier \& CohenBazire, 1977). As células destes procariotos possuem um aparato fotossintetizante similar estrutural, molecular e funcionalmente àqueles contidos em cloroplastos. Devido a essas características, esses organismos já foram classificados como algas, sendo chamados de cianofíceas ou algas verdeazuladas. Porém, depois de feita a descrição da estrutura morfológica e química do envoltório celular como a de uma bactéria gram-negativa, estes organismos foram transferidos do Sistema Botânico de Classificação para o Sistema Bacteriano de Classificação (Stanier, 1977; Stanier \& Cohen-Bazire, 1977). Este grupo de organismos que era estudado apenas pelos ficologistas passou, também, a ser objeto de estudo dos microbiologistas. Observa-se, porém, um número ainda pequeno de estudos feitos por microbiologistas com estes organismos, em parte devido a esta característica dual de bactéria e planta.

As cianobactérias produzem clorofila a e pigmentos chamados ficobilinas, que participam do sistema fotossintetizante (com exceção do gênero Prochlorothrix que produz clorofila $b$ e não possui ficobilinas). Os termos cianofícea/cianobactéria originaram-se a partir do nome de uma classe de ficobilina, a ficocianina. A água é o doador inicial de elétrons durante a 
fotossíntese e o produto final é o oxigênio (Stanier, 1977; Stanier \& CohenBazire, 1977). Essas características diferenciam as cianobactérias de outros procariotos fotossintetizantes, como as bactérias púrpuras e verdes (Imhoff, 1992).

\subsubsection{História evolutiva e tolerância a ambientes adversos}

As cianobactérias possuem uma longa história evolutiva na Terra, podendo datar 3500 milhões de anos. A mudança de uma atmosfera anóxica para uma contendo oxigênio foi causada pela atividade fotossintetizante dos organismos ancestrais as cianobactérias atuais. Robinson et al. (2000) sugerem que um dos motivos para o sucesso desses organismos em ambientes considerados adversos para outros organismos foi devido a sua longa história evolutiva. Eles consideram que a mudança na composição de metais nos ambientes primitivos, ocasionada pela liberação de oxigênio na atmosfera, pode ter influenciado na evolução de mecanismos de resistência a metais e surgimento de proteínas que utilizam metais em cianobactérias. Além da tolerância a metais, representantes deste grupo tem capacidade de tolerar outras condições ambientais adversas, tais como ambientes com pouco oxigênio e sulfeto livre (Stal, 2000), alta radiação ultra-violeta (Castenholz \& Garcia - Pichel, 2000), altas temperaturas (Castenholz \& Garcia - Pichel, 2000; Castenholz \& Waterbury, 1989), ambientes altamente salinos (Bauld, 1981) e dessecação (Whitton, 1991). As cianobactérias também são capazes de realizar fotossíntese utilizando baixa intensidade luminosa (Paerl, 2000).

\subsubsection{Synechococcus leopoliensis PCC7942}

O gênero Synechococcus compõe um grupo de cianobactérias unicelulares e com divisão binária dentro da ordem Chrooccales. A taxonomia das cianobactérias é feita através da avaliação de caracteres morfológicos, fisiológicos e genotípicos. Para algumas cianobactérias, diferentes análises foram realizadas como a composição dos pigmentos fotossintetizantes, 
composição lipídica, composição de base do DNA, tamanho do genoma (Kenyon et al, 1972; Herdman et al, 1979; Rippka et al, 1979, citados por Wilmotte, 1994). Ultimamente, também, têm-se feito comparações e agrupamentos entre diferentes linhagens através da análise de alguns genes conservados como o gene codificador do 16S rRNA (Honda et al., 1999; Robertson et al., 2001; Schönhuber et al., 1999), e também, com menor freqüência, o gene da ficocianina (Baker et al., 2001; Neilan et al., 1995; Tillett et al., 2001).

A linhagem utilizada neste estudo, a Synechococcus sp. PCC7942 já foi classificada como Anacystis nidulans (Rippka et al, 1979; Thiel \& Wolk, 1987, citados por Golden et al., 1989), e atualmente, observa-se na literatura como Synechoccocus elongatus (Wilmotte \& Stam, 1984) e Synechoccocus leopoliensis (Grigorieva \& Shestakov, 1976; Shestakov \& Reaston, 1987), sendo este último nome adotado na Coleção de Culturas do Instituto Pasteur (www.pasteur.fr/recherche/banques/PCC/)

\subsection{Cianobactérias como modelo para estudos genéticos, bioquímicos e fisiológicos}

As cianobactérias unicelulares Synechococcus sp. e Synechocystis sp. têm sido utilizadas como organismos modelos em estudos, em sua maior parte, sobre os mecanismos envolvidos na fotossíntese. A espécie Synechocystis sp. PCC6803 é naturalmente transformável (Grigorieva \& Shestakov, 1982), e capaz de crescimento heterotrófico além do autotrófico, o que possibilitou estudos sobre os mecanismos de fotossíntese através de mutantes deficientes nos fotossistemas I e II (Kotani \& Tabata, 1998). A teoria onde se propõe a origem dos cloroplastos a partir do engolfamento de um ancestral de cianobactéria por uma célula eucariótica e posteriores relações de simbiose tem recebido respaldos através dos estudos de homologia entre genes de cloroplastos e de Synechococcus sp. PCC6803 (Sigrun \& Keegstra, 1999). A relação filogenética próxima entre cloroplastos e cianobactérias permite a 
utilização deste organismo como modelo para o estudo da fotossíntese em algas e plantas.

A capacidade de transformar células de cianobactéria tem sido aprimorada com outras espécies além da Synechocystis sp. PCC6803, como na espécie de cianobactéria termofílica, Thermosynechoccous elongatus (Iwai et al., 2004; Onai et al., 2004).

O genoma de algumas cianobactérias foram completamente seqüenciados e estão disponíveis no site Cyanobase (http://www.kazusa.or.jp/cyano) dentre elas o genoma da Synechocystis PCC6803 (Kaneko et al., 1995) e Thermosynechococcus elongatus BP-1 (Nakamura et al., 2002).

\subsection{Estudos proteômicos em cianobactérias}

Após o sequenciamento do genoma da Synechocystis sp. PCC6803 foi realizada a análise do proteoma desta cianobactéria pelo mesmo grupo de pesquisadores (Sazuka \& Ohara, 1997). Neste estudo, as proteínas foram separadas através da técnica de eletroforese bi-dimensional (2D-PAGE), tiveram suas extremidades $\mathrm{N}$-terminais seqüenciadas (microsequenciamento) e 130 proteínas foram identificadas através da comparação direta com os genes anotados provenientes do sequenciamento do genoma desta cianobactéria. Esses autores também testaram a eficiência da metodologia de separação e identificação de proteínas para a avaliação de genes diferencialmente expressos. Culturas de Synechocystis sp. PCC6803, previamente submetidas a fontes luminosas com diferentes intensidades, tiveram suas proteínas analisadas através de gel bi-dimensional. Três proteínas expressas diferencialmente foram selecionadas, sendo duas delas identificadas com sucesso. Sazuka et al. (1999) realizaram uma extensão do estudo proteômico de Synechocystis sp. PCC6803, utilizando a mesma metodologia de separação e identificação de proteínas, porém, fracionando as proteínas extraídas e promovendo uma separação entre as proteínas solúveis, insolúveis, da 
membrana do tilacóide, e secretórias. Este fracionamento possibilitou uma melhor separação e um aumento no número de proteínas identificadas totalizando 227. Entretanto, o método utilizado de sequenciamento da extremidade N-terminal foi classificado por Sazuka \& Ohara (1997) limitante em alguns aspectos, como a ineficiência na identificação de proteínas com alto peso molecular (> $70 \mathrm{kDa}$ ) e de proteínas pouco abundantes. Esse autor propôs a utilização de métodos de espectrometria de massa, por apresentar maior sensibilidade e rapidez do que o de microsequenciamento.

Em estudos posteriores sobre o proteoma da Synechocystis sp. PCC6803 a separação das proteínas continuou sendo realizada através de 2D-PAGE, porém a identificação passou a ser feita através de técnicas de espectrometria de massa, principalmente por MALDI-TOF (espectrometria de massa com ionização a laser e tempo de vôo).

Diversos estudos sobre as proteínas constituintes das membranas desta cianobactéria foram realizados. Wang et al. (2000) estudaram as proteínas periféricas das membranas do tilacóides, identificando 78 proteínas entre 116 proteínas analisadas. Huang et al. (2002) analisaram e identificou 57 proteínas da membrana plasmática e Huang et al $(2004)^{1}$ identificaram 59 proteínas da membrana externa do envoltório celular. Herranen et al. (2004) estudaram os complexos de proteínas de membrana, encontrando complexos envolvidos no processo fotossintético de transferência de elétrons e formação de ATP (fotossistemas PSI e PSII, citocromo $B_{6} f$ e ATP sintase), quatro complexos contendo $\mathrm{NAD}(\mathrm{P}) \mathrm{H}$ desidrogenase tipo I, e outros complexos protéicos ainda não caracterizados. Um estudo sobre proteínas as solúveis da cianobactéria foi realizado por Simon et al. (2002), onde, das 192 proteínas analisadas, 105 foram identificadas.

\footnotetext{
${ }^{1}$ HUANG, F.; HEDMAN, E.; FUNK, C.; KIESELBACH, T.; SCHRÖDER, W.; NORLING, B. Isolation of outer membrane of Synechocystis sp. PCC 6803 and its proteomic characterization. Molecular \& Cellular Proteomics, 2004. /No prelo/
} 


\subsection{Estudo de expressão diferencial de genes de cianobactérias em situações de estresse}

Os estudos mais comuns sobre regulação gênica em cianobactérias em situações de estresse avaliam os seguintes fatores ambientais: a escassez de nutrientes, a intensidade de luz recebida e variação da temperatura ambiental fora da faixa ótima. Alguns desses estudos são apresentados a seguir.

\subsubsection{Respostas à escassez de nutrientes e diferentes intensidades luminosas}

Algumas respostas metabólicas à escassez de nutrientes são específicas a um determinado nutriente e outras são gerais para um grupo de nutrientes. No primeiro caso, há um aumento na síntese de sistemas de transporte específico e de enzimas que transformam formas inacessíveis de nutrientes naquelas que as células podem utilizar. No segundo caso, há mudanças na morfologia celular, nas reservas intracelulares de nutrientes, e na atividade de diversos processos metabólicos, inclusive a fotossíntese (Grossman et al., 1994). A escassez de micronutrientes como o ferro e o cobre pode ocasionar a expressão de proteínas que não apresentam estes metais em sua estrutura, substituindo aquelas que os apresentam em sua estrutura.

O ferro, considerado essencial para a célula, quando escasso provoca, em algumas cianobactérias, a substituição da metalo-proteína ferrodoxina, componente da cadeia fotossintética de transporte de elétrons, pela flavodoxina (Bryant, 1986; Laudenbach et al, 1988; Fillat et al, 1991; Bottin \& Lagoutte, 1992, citados por Grossman et al., 1994) através da indução da transcrição desta última.

Alguns genes que tem sua expressão aumentada durante a escassez de ferro são os $i d i A$, idiB , isiA e isiB (Yousef et al., 2003). Sendo que, já foi relatado em Synechocystis sp. PCC6803 a indução dos dois últimos genes em situações de estresse salino (Fulda et al., 2000). Quando há limitação do cobre, algumas cianobactérias são capazes de substituir a plastocianina, a qual 
contém cobre em sua estrutura, pelo citocromo c553 (Ho \& Krogmann, 1984; Bryant, 1986; Sandmann, 1986; Briggs et al, 1990, citados por Grossman et al., 1994). Foi demonstrado em diversos estudos com Synechococcus sp. que a escassez do macronutriente nitrogênio provoca a degradação de ficobiliproteínas, os principiais pigmentos de captura de luz do sistema fotossintetizante, e de outras proteínas. Esse processo, conhecido como clorose, pode ser rapidamente revertido pelo acréscimo de nitrogênio no meio (Görl et al., 1998). Em estudos sobre a limitação de outro macronutriente, o fósforo, demonstrou-se o acúmulo da proteína periplasmática fosfatase alcalina em Synechococcus sp. PCC 7942 (Block \& Grossman, 1988).

A degradação das ficobiliproteínas ocorre em resposta a outros estresses ambientais além da escassez de nitrogênio, como a alta intensidade luminosa. A proteína que provavelmente desencadeia esse processo de degradação é a NbIA (Collier \& Grossman, 1994), a qual tem sua expressão controlada pela proteína NbIR (Schwarz \& Grossman, 1998).

A exposição de cianobactérias e plantas a raios intensos de luz ocasiona um mecanismo bem conhecido, a troca das subunidades D1 do fotossistema II, promovendo maior resistência aos danos foto-oxidativos nas células. Nesse processo, a transcrição do gene expresso em situações de baixa luminosidade ( $p s b A l)$ é reduzida, e outros dois genes ( $p s b A l l$ e psbAlll) tem seu nível de transcrição aumentado. Em Synechococcus sp. PCC7942, outro gene que tem sua expressão aumentada em alta luminosidade e com incidência de luz ultravioleta é o hliA (Bustos et al., 1990).

\subsubsection{Respostas a altas temperaturas}

Organismos pertencentes aos domínios Archaea, Bacteria e Eukarya possuem um sistema conservado de resposta a altas temperaturas. Neste sistema há indução de proteínas de choque térmico ou proteínas "heat shock" (hsp). Esse mecanismo foi mais bem estudado em E.coli dentre as bactérias (Webb, 1994), porém, a resposta de proteínas de choque térmico em 
cianobactérias é semelhante a da E. coli. A mudança de temperatura causa, em minutos, a repressão de algumas proteínas e superexpressão de outras. Dentre as proteínas superexpressas, há cinco que são conhecidas por atuar como chaperonas moleculares, a DnaK, DnaJ, GroEL, GroES e GrpE, as quais modulam várias tipos de reações proteína-proteína. Essas proteínas mediam a união de polipeptídeos e a reestruturação da forma tridimensional de proteínas desnaturadas. A expressão das proteínas de choque térmico não ocorre apenas como resposta a estresse térmico, pelo contrário, várias outras fontes de estresse podem desencadear esta reação, entre eles, escassez de carbono e fosfato, exposição a etanol, antibióticos e metais pesados. A indução das proteínas de choque térmico está sob controle do ativador $\sigma^{32}$, produto do gene $\mathrm{rpoH}$ Este fator $\sigma$ liga-se ao centro da RNA polimerase e permite que esta reconheça os promotores dos genes codificadores para as proteínas de choque térmico (Grossman et al, 1984 citado por Webb, 1994).

\subsubsection{Respostas a metais pesados}

Os mecanismos moleculares mais estudados em cianobactérias expostas a metais pesados é a indução do sistema de proteínas de choque térmico, o aumento na atividade de enzimas anti-oxidantes e, no caso da Synechococcus sp. PCC7942, a expressão da proteína seqüestradora de metais metalotioneína.

As metalotioneínas são um grupo de proteínas de baixo peso molecular ( $<10 \mathrm{kDa}$ ) ricas em cisteína. A ligação dos metais é feita nos grupos sulfidrílicos desse aminoácido. Através do sequenciamento do genoma de algumas cianobactérias e pseudomonas, observou-se que seqüências de prováveis genes (ORFs - quadros abertos de leitura) eram semelhantes ao gene que codifica para a metalotioneína, porém, dentro do domínio Bacteria, somente em Synechococcus sp. PCC7942 o gene que codifica para esta proteína, bem como a proteína em si foram isolados e seqüenciados (Huckle et al., 1993; 
Robinson et al., 1990). Recentemente, a estrutura dessa proteína foi descrita na literatura (Blindauer et al., 2001).

Esta proteína pode ser induzida pela presença dos metais zinco, cádmio, mercúrio, cobre, cobalto, crômio e níquel (Huckle et al., 1993). Os genes da metalotioneína estão arranjados em um operon chamado smt, o qual contém o gene codificador $s m t A$ e o repressor $s m t B$. O repressor SmtB se liga a região promotora impedindo a transcrição da metalotioneína. Quando há metal no meio este interage com o repressor, através de uma região rica em cisteína, possibilitando a expressão da metalotioneína (Erbe et al., 1995).

\subsection{Efeitos tóxicos de metais pesados em cianobactérias e mecanismos de tolerância}

O efeito dos metais sobre o estado fisiológico da célula pode ser classificado, segundo alguns autores como benéfico, maléfico ou indiferente (Beveridge et al., 1997). Os metais classificados como maléficos, ou tóxicos, não possuem função conhecida na célula, podendo-se citar: $\mathrm{Ag}, \mathrm{Cd}, \mathrm{Sn}, \mathrm{Au}$, $\mathrm{Hg}, \mathrm{Tl}, \mathrm{Pb}, \mathrm{Bi}$, e Al. De maneira general, a toxicidade que esses metais exercem na célula é devido a habilidade destes de estabelecerem pontes estáveis com componentes celulares. Eles podem causar destruição da membrana (citoplasmática e de componentes celulares) através da peroxidação de lipídios, interagir com enzimas e interferir em sua atividade, e causar dano direto ao DNA (Aruoma et al, 1991; Gutteridge et al, 1990; Kronmann et al, 1984; Schreurs \& Rosenberg, 1982; Beyersmann, 1994, citados por Rouch et al., 1995).

Alguns mecanismos de toxicidade do cádmio em células de cianobactérias foram estudados. Um deles é a ligação do cádmio a enzimas posteriormente ao deslocamento do zinco. Alguns exemplos de enzimas inibidas pela ação deste metal são a fosfatase alkalina, anidrase carbônica, dipeptidase e aldolase (Valle \& Ulmer, 1972, citado por Vymazal, 1987). Rachlin (1984) observou que em Anabaena flos-aquae a presença do cádmio causava 
redução na área dos tilacóides, a mudança na estrutura e número de alguns inclusões celulares como os grânulos de polifosfato, inclusões lipídicas, grânulos de cianoficina, e mudança no volume das camadas do envoltório celular. Singh \& Yadava (1984) observaram em culturas de Anacystis nidulans que a presença de cádmio inibiu a captura de íons amônio e fosfato pelas células. Bolaños et al. (1992) demonstraram que o cádmio causa uma redução

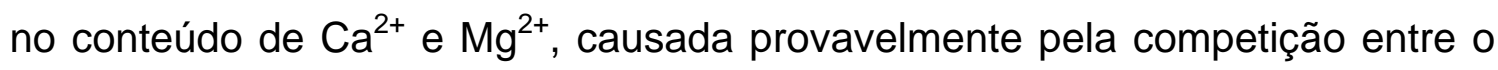
$\mathrm{Cd}^{2+}$ e esses íons por sítios de ligação celular. Bolaños et al. (1992) propuseram que o decréscimo dos íons $\mathrm{Ca}^{2+}$ poderia explicar a alteração no crescimento e divisão celular que o cádmio promove, e que a substituição do $\mathrm{Mg}^{2+}$ pelo $\mathrm{Cd}^{2+}$ poderia estar relacionado com a diminuição na quantidade de clorofila nas células e isso poderia explicar o decréscimo nas taxas de fotossíntese.

Os mecanismos de tolerância a metais tóxicos descritos em cianobactérias são precipitação extracelular do metal, ligação dos íons a uma camada de mucilagem que envolve a célula, presença de uma membrana com permeabilidade seletiva para certos íons, exclusão dos íons por sistemas ativos de transporte, captura intracelular dos íons por proteínas, e armazenamento em algumas inclusões celulares como os grânulos de polifosfato. Neste último mecanismo, o metal no interior da célula é retido nessas inclusões celulares diminuindo a sua interação com outros componentes celulares e impedindo a sua ação nociva.

Ferianc et al. (1998) estudaram a expressão gênica de E. coli em situação de estresse causado pela presença de cádmio, utilizando-se as técnicas de gel-bidimensional e sequenciamento do N-terminal. As proteínas foram classificadas em dois grupos: (1) Proteínas expressas em resposta a um estímulo específico (cádmio). Este grupo era composto pela quinase adenilada, proteína-W, H-NS, UspA, a proteína de choque térmico frio G041.2 e sete proteínas não identificadas. (2) Proteínas expressas em resposta a mais de um estímulo (resposta generalizada). Este grupo era composto por proteínas de 
choque-térmico, proteínas envolvidas em estresse oxidativo e SOS. As proteínas dos dois grupos foram expressas apenas durante o período em que o crescimento celular estava afetado, depois da adaptação ao cádmio elas tiveram sua expressão suprimida.

\subsection{Biotecnologia ambiental}

Os microrganismos capazes de sobreviver na presença de metais tóxicos, seja devido a mecanismos de exclusão ou imobilização intracelular do metal, podem ser utilizados na aplicação de técnicas de biotecnologia ambiental como o monitoramento de áreas naturais contaminadas por metais ou, até mesmo, na sua recuperação.

A capacidade de remoção de metais de águas contaminadas já foi descrito em diversas espécies de cianobactéria. A captura de metais do meio pelas cianobactérias geralmente envolve duas etapas: a passiva, que envolve a adsorção de cátions a grupos carregados negativamente presentes no envoltório celular, e a ativa, onde ocorre a internalização dos cátions ligados ao envoltório por mecanismos de transporte envolvendo atividade metabólica da célula. Esses mecanismos já foram descritos para o cádmio, cobre e zinco em Anacystis nidulans e em Chrococcus paris, para o níquel, mercúrio e cromo em Anabaena cylindrica, Nostoc calcícola e Anabaena doliolum, respectivamente (Campbell \& Smith, 1986; Les \& Walker, 1984; Pandey \& Singh, 1993; Dubey \& Mallick, 1992; Schecher \& Driscol, 1985; Shehata \& Whiton, 1982; Singh, 1985; Singh \& Yadava, 1985; Verma \& Singh, 1991, citados por Fiore et al., 1998).

Gardea-Torresdey et al. (1998) utilizaram células de Synechococcus sp. PCC7942 como biomassa imobilizada em sílicas empacotadas em uma coluna, e observou que esse sistema removia íons de águas contaminadas por cobre, chumbo, níquel, cádmio e chumbo. Nesse sistema, foram possíveis a adsorção e eluição dos metais em vários ciclos sem perder a sua capacidade de remoção dos metais do meio. Esses autores sugerem que a super- 
expressão da metalotioneína em Synechococcus sp. PCC7942 manipuladas geneticamente poderia aumentar a capacidade de captura dos metais.

Alguns trabalhos relatam o estudo da utilização de biomassa de cianobactérias e algas para aumentar a sensibilidade das análises e quantificação, por espectrometria, de metais traços presentes em concentrações muito baixas nas amostras (partes por trilhão e partes por bilhão). Isso ocorreu através da pré-concentração desses metais realizada pela ação acumuladora desses organismos (Shengjun \& Holcombe, 1991; Harris \& Remelow, 1990; Nakajima et al, 1982; Zimmik \& Sneddon, 1988; Jeffers et al, 1989, citados por Maquieira et al., 1994).

A construção de sistemas de detecção de metais no meio utilizando-se mecanismos biológicos de resposta a metais também é relatado na literatura. A região do DNA do microrganismo relacionada à resposta a metais foi ligada ao gene repórter lux, e quando essa região era transcrita resultava na emissão de luz devido à ação da luciferase. (Corbisier et al, 1993; Corsibier et al, 1999, citados Bontidean et al., 2000). Nesse sistema é feita a detecção dos metais que estão biodisponíveis para a célula. Em outros sistemas desenvolvidos para a detecção de metais utilizando-se propriedades metabólicas de microrganismos, a atividade acumuladora de metais pela metalotioneína e a interferência causada no sistema fotossintetizante por metais e pesticidas é traduzida em sinais elétricos (Bontidean et al., 2000; Rouillon et al., 1999).

Os sistemas biotecnológicos apresentados acima estão em sendo aperfeiçoados e não constituem, ainda, técnicas robustas para aplicação. $\mathrm{O}$ entendimento dos mecanismos moleculares e bioquímicos envolvidos nas respostas de microrganismos a metais tóxicos pode trazer colaborações ao aperfeiçoamento dessas técnicas. 


\section{MATERIAL E MÉTODOS}

\subsection{Cultivo da cianobactéria}

A cianobactéria Synechococcus leopoliensis PCC7942 foi obtida pelo Laboratório de Biologia Celular e Molecular do CENA da coleção de culturas do Instituto Pasteur, Paris, França. Essa linhagem é mantida em meio de cultura

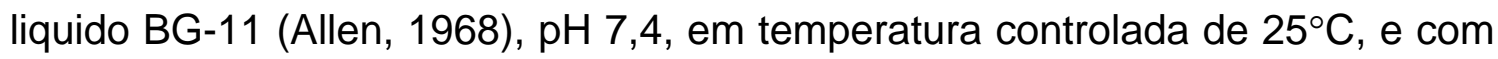
iluminação fluorescente constante de $40 \mu$ moles $\mathrm{m}^{2} \bullet \mathrm{s}^{-1}$. Essas condições de crescimento foram utilizadas em todos os experimentos desenvolvidos neste trabalho.

\subsection{Reagentes químicos utilizados}

Os reagentes utilizados no preparo do meio de cultura BG-11 de grau de ultra-pureza foram obtidos da Sigma-Aldrich (St. Louis, MO, EUA) e Merck (Dramstadt, Alemanha).

\subsection{Curva de crescimento da cianobactéria}

O crescimento das culturas da cianobactéria foi monitorado através da medida da densidade ótica usando o espectrofotômetro Lambda Bio (Applied Biosystems, Foster City, CA, EUA), no comprimento de onda $750 \mathrm{~nm}$ de acordo com Lee et al. (1991) e Thompson et al. (2002). Esse experimento foi realizado utilizando uma cultura inicial (inóculo) de dez dias de idade. Para a obtenção de inóculos com valores padronizados de densidade ótica $\left(\mathrm{DO}_{750 \mathrm{~nm}}\right)$ próximos de 0,08, essa cultura inicial de cianobactéria foi concentrada através de centrifugação (12000 xg, 5 minutos, $\left.4^{\circ} \mathrm{C}\right)$, sendo o sobrenadante descartado. $\mathrm{O}$ 
precipitado foi ressuspendido em $5 \mathrm{~mL}$ de meio BG-11 e alíquotas de $200 \mu \mathrm{L}$ dessa cultura ressuspendida foram inoculadas em 20 frascos erlenmeyers de $50 \mathrm{~mL}$ contendo $20 \mathrm{~mL}$ de meio líquido BG-11. Essas culturas foram mantidas nas condições descritas anteriormente (item 3.1), e seu crescimento foi monitorado através de amostragens a cada 48 horas durante um período de 8 dias $(0,2,4,6$ e 8 dias). Em cada época de amostragem foram retiradas alíquotas $(1 \mathrm{~mL})$ de culturas de três erlenmeyers diferentes (três repetições) e feitas determinações de $D O_{750 n m}$. Também foi realizada a contagem de células, seguindo o método de contagem de cianobactérias unicelulares descrito por Vieira et al. (2003). Nessa contagem utilizou-se a câmara de contagem de células Fuchs-Rosenthal (Bright line, Boeco, Alemanha) e um microscópio ótico (Zeiss, Bonn, Alemanha) no aumento de 400 vezes.

As médias e desvios padrões dos valores das medidas de densidade ótica e número de células das três repetições de cada amostragem foram calculadas e a correlação entre esses dois parâmetros foi determinada. Essa correlação foi usada para obter valores de número de células em experimentos posteriores de curva de crescimento onde apenas as medidas de densidade ótica foram realizadas.

O gráfico da curva de crescimento foi traçado a partir das médias dos valores de contagem de células das triplicatas, utilizando-se o programa SigmaPlot versão 4.01 (SPSS Inc., Chicago, IL, EUA). Através desta curva foram analisadas as fases de crescimento (adaptação, logarítmica e estacionária) das culturas. A partir desta primeira curva foi feito o planejamento dos experimentos de avaliação da dose máxima de cádmio tolerável pela Synechococcus leopoliensis PCC7942 e de análise comparativa do proteoma da cianobactéria em resposta ao cádmio, descritos a seguir. 


\subsection{Determinação da dose máxima de Cd tolerável pela Synechococcus leopoliensis PCC7942 e curva de crescimento da cianobactéria na presença de cádmio}

A concentração máxima de cádmio tolerável pela Synechococcus elongatus PCC7942 foi determinada através da avaliação de crescimento das culturas. Inóculos ( $3 \mathrm{~mL}$ ) da cianobactéria, retirados de uma cultura na fase final logarítmica de crescimento $\left(\mathrm{DO}_{750 \mathrm{~nm}} 2,0\right)$, foram adicionados em erlenmeyers de $125 \mathrm{~mL}$ contendo $50 \mathrm{~mL}$ de meio BG-11 e concentrações de 1, 3 e $5 \mu \mathrm{M}$ de $\mathrm{CdCl}_{2}$ (Merck). O crescimento das cianobactérias na presença de diferentes concentrações do metal foi monitorado através da leitura da densidade ótica destas culturas, num intervalo de 48 horas, utilizando-se o espectrofotômetro no comprimento de onda de $750 \mathrm{~nm}$ (conforme descrito no item 3.3). O número de células das culturas amostradas foi estimado através dos valores obtidos de densidade ótica (conforme citado no item 3.3). A partir do número de células foram determinados as fases de crescimento e o tempo de geração.

O gráfico de curva de crescimento foi traçado utilizando-se o programa SigmaPlot ver. 4,01 (SPSS Inc.) e o tempo de geração ( $g$ ), também chamado de tempo de duplicação, foi calculado utilizando-se a seguinte equação:

$$
g=\frac{t \log 2}{\log b-\log B}
$$

onde:

$\mathrm{g}$ = tempo de geração

$B=$ Número de células em algum ponto do início da fase logarítmica

$b=$ Número de células em algum ponto do fim da fase logarítmica

$t=$ Intervalo de tempo, em horas, entre $B$ e $b$ 


\subsection{Curva de crescimento de culturas na presença da máxima concentração tolerável de cádmio e acúmulo do metal pelas células}

Todos os materiais utilizados neste ensaio foram previamente lavados com $\mathrm{HNO}_{3} 10 \%$ e água ultra-pura para minimizar a contaminação ambiental por metais.

Depois de definida a concentração máxima de cádmio tolerável pela cianobactéria foram analizados o crescimento e acúmulo de metal pelas células nesta concentração do metal. O experimento de curva de crescimento foi realizado a partir de 2 inóculos retirados no final da fase logarítimica de crescimento, o primeiro, obtido de células crescidas em meio BG-11 sem metal (controle), e o segundo de células crescidas em meio BG-11 com $3 \mu \mathrm{M}$ de Cd (essa concentração de cádmio foi escolhida baseando-se nos resultados obtidos no ensaio de tolerância). Para a obtenção da quantidade de inóculo que resultasse em densidade celular inicial de valores próximos a $\mathrm{DO}_{750 \mathrm{~nm}}$ 0,08, essas culturas de cianobactérias foram concentradas através de centrifugação (12000 xg, 5 minutos, $4^{\circ} \mathrm{C}$ ), sendo o sobrenadante descartado. Os precipitados do controle e da cultura com metal foram ressuspendidos em $6 \mathrm{~mL}$ de meio BG11. Sessenta erlenmeyers de $50 \mathrm{~mL}$ contendo $20 \mathrm{~mL}$ de meio $B G-11$, sendo 30 com $3 \mu \mathrm{M}$ de $\mathrm{Cd}$ e $30 \mathrm{sem} \mathrm{Cd}$, foram inoculados com $200 \mu \mathrm{L}$ do precipitado ressuspendido em $6 \mathrm{~mL}$ de meio BG-11 proveniente da cultura crescida na presença do metal e da cultura sem metal, respectivamente. As culturas inoculadas nos 60 frascos de erlenmeyers cresceram nas condições descritas anteriormente (item 3.1), sendo as amostragens realizadas a cada 48 horas, em triplicata, no período de 12 dias (0, 2, 4, 6, 8 e 12 dias). Em cada amostragem foram retiradas alíquotas do controle e do tratamento com metal para as medidas de crescimento através da densidade ótica. Também foram coletadas amostras para a quantificação de cádmio acumulado pelas células.

O número de células das culturas amostradas foi estimado através dos valores obtidos de densidade ótica (conforme citado no item 3.3). A partir do número de células foram determinados as fases de crescimento e o tempo de 
geração. O experimento de curva de crescimento foi realizado duas vezes Experimento 1 e 2).

O cádmio acumulado pelas células foi analisado em culturas no início e fim da fase logarítmica, e na fase estacionária. Essas amostras foram concentradas através de centrifugação (12000 xg, $\left.4^{\circ} \mathrm{C}, 5 \mathrm{~min}\right)$ e lavadas três vezes com 0,5 mL de EDTA $5 \mathrm{mM}$ (forte quelante de metais) $\mathrm{pH} 8,0$, para a remoção dos íons metálicos adsorvidos no envoltório celular das células de cianobactérias. Após a lavagem, os precipitados foram pesados, pois a concentração de cádmio contido nas cianobactérias foi calculada, posteriormente, utilizando-se o valor da massa fresca das células precipitadas. A quantificação do cádmio contido nas células da cianobactéria das amostras controles e com $3 \mu \mathrm{M}$ de cádmio foi realizada usando o espectrômetro de absorção atômica Varian SpectrAA-220 (Varian, Mulgrave, Victoria, Austrália) equipado com forno GTA 110 para aquecimento do atomizador de grafite.

\subsection{Especiação do $\mathrm{CdCl}_{2}$ no meio de cultura BG-11}

O comportamento do $\mathrm{CdCl}_{2}$ nas concentrações 1,5 , 3 e $100 \mu \mathrm{M}$ no meio de cultura BG-11, ou seja, a formação de espécies químicas de cádmio através das interações deste metal com os componentes do meio de cultura (sais e complexantes de metal) foi avaliado usando o programa Visual MINTEQA2 ver. 2.23 (Allison et al., 1990). Esse programa de computador, disponível no sítio http://www.Iwr.kth.se/English/OurSoftware/vminteq/, calcula a atividade e concentração das espécies químicas em solução. Para essa análise, foi feita a entrada no programa dos componentes do meio de cultura com suas respectivas concentrações e as diferentes concentrações de cádmio. Estabeleceram-se, também, as condições ambientais de pH 7,4 e temperatura $25^{\circ} \mathrm{C}$.

Esta análise foi realizada visando conhecer a concentração da forma iônica $\mathrm{Cd}^{+2}$, considerada a mais tóxica do cádmio no meio de cultura onde as 
células de cianobactérias tiveram o seu crescimento e expressão gênica avaliados.

\subsection{Estudo comparativo de proteomas de Synechococcus leopoliensis PCC 7942 em resposta ao cádmio}

\subsubsection{Reagentes químicos utilizados}

Durante as etapas de focalização isoelétrica, corrida eletroforética e coloração do gel, foram utilizados reagentes com grau de ultra-pureza provenientes da Amersham plus One (Amersham Biosciences, Piscataway, NJ, EUA), Sigma (St. Louis, MO, EUA), Merck (Dramstadt, Alemanha) e Invitrogen (Carlsbad, CA, EUA).

\subsubsection{Cultivo das cianobactérias e adição de cádmio}

De uma cultura no final da fase logarítmica $\left(\mathrm{DO}_{750 \mathrm{~nm}} 2,0\right)$, crescendo em erlemeyer de $1000 \mathrm{~mL}$ contendo $500 \mathrm{~mL}$ de meio BG-11, nas condições descritas no ítem 3.1 e sob agitação constante (110 rpm), foram retirados três alíquotas de $150 \mathrm{~mL}$ sendo cada uma transferida para um frasco erlenmeyer esterilizado de $500 \mathrm{~mL}$. No primeiro erlenmeyer foi adicionado $3 \mu \mathrm{M}$ de cádmio (máxima concentração tolerável), no segundo foi adicionado $100 \mu \mathrm{M}$ de cádmio (quantidade letal) e no terceiro não foi adicionado metal (controle). Os frascos foram incubados durante uma hora na câmara de crescimento com luz e temperatura constantes (condições descritas no item 3.1). Após permanecerem em contato com o cádmio durante uma hora, as células foram concentradas através de centrifugação (12000 xg, 4º $\mathrm{C}, 5$ minutos). As células precipitadas foram lavadas três vezes com uma solução de $10 \mathrm{mM}$ de Tris- $\mathrm{HCl}$ pH 8,8, $3 \mathrm{mM}$ de $\mathrm{KCl}$ e $50 \mathrm{mM}$ de $\mathrm{NaCl}$ (numa relação de $10 \mathrm{~mL}$ de solução para $100 \mathrm{~mL}$ de cultura de cianobactérias) para remoção de polissacarídeos e íons metálicos aderidos reversivelmente na parede celular das células. 
A exposição das células de cianobactérias a essas duas doses de cádmio durante uma hora foi realizada duas vezes em tempos diferentes.

Para todos os tratamentos (controle, 3 e $100 \mu \mathrm{M}$ cádmio) foram coletadas alíquotas de 1,5 mL de culturas, as quais foram processadas para a quantificação de cádmio acumulado pelas células, conforme descrito no ítem 3.4 .4

\subsubsection{Extração e quantificação de proteínas}

A extração de proteínas das células de cianobactérias expostas e não expostas às duas doses de cádmio nos diferentes tempos foi realizada usando uma metodologia desenvolvida para extração de proteínas da bactéria Xylella fastidiosa (Bellato et al.,2003) ${ }^{1}$, conforme descrita a seguir.

As células de cianobactérias precipitadas e lavadas conforme citado acima, foram ressuspendidas em uma solução com 50 mM de Tris- $\mathrm{HCl}$ pH 8,8, 1,5 mM de $\mathrm{MgCl}_{2}, 1,0 \mathrm{mM}$ de EDTA, 10,0 mM de ditiotreitol (DTT) e uma mistura de inibidores de proteinases (Cocktail set II, cat. $\mathrm{n}^{\circ} 539132$, Calbiochem, Merck) numa relação de $5 \mathrm{~mL}$ dessa solução para $20 \mathrm{~g}$ de células. As células contidas nessa solução foram rompidas mecanicamente através do sistema de ruptura de células BioNeb (Glas-Col, Terre Haute, IN, EUA) a uma pressão de $8 \mathrm{kgf} \mathrm{cm}^{-2}$ e com uma taxa de fluxo de nitrogênio de 17,0 L min $\mathrm{m}^{-1}$. Em seguida, adicionou-se $0,1 \%$ de dodecil sulfato de sódio (SDS) e foi deixado incubando durante 15 minutos na temperatura de aproximadamente $25^{\circ} \mathrm{C}$, visando otimizar o rompimento das células. Após esse período, as amostras foram centrifugadas a $8000 \mathrm{xg}$, a temperatura de $4^{\circ} \mathrm{C}$, por 2 minutos e $\mathrm{o}$ sobrenadante contendo as proteínas foi reservado, sendo que o precipitado

\footnotetext{
${ }^{1}$ BELLATO, C.M.; GARCIA, A.K.M.; MESTRINELLI, F.; TSAI, S.M.; MACHADO, M.A.; MEINHARDT, L.W. The induction of differentially expressed proteins of Xylella fastidiosa with citrus extract. Brazilian Journal of Microbiology, 2004. /Trabalho submetido/
} 
contendo outros compostos celulares foi descartado. Três alíquotas de $50 \mu \mathrm{L}$ foram retiradas do sobrenadante para a quantificação da concentração de proteína através da comparação com uma curva padrão de BSA (soro de albumina bovina), de acordo com o método de Bradford (1976). O restante das amostras foi separado em alíquotas de $75 \mu \mathrm{g}$, as quais foram acondicionadas em tubos de eppendorf, liofilizadas e armazenadas a ${ }^{-2} 20^{\circ} \mathrm{C}$. Todos os passos descritos acima foram realizados com as amostras sendo manuseadas no gelo para evitar a degradação das proteínas.

\subsubsection{Eletroforese bidimensional}

\subsubsection{Focalização isoelétrica (primeira dimensão)}

A separação das proteínas foi primeiramente realizada de acordo com os seus pontos isoelétricos $(p /)$, através do processo de focalização isoelétrica (IEF) utilizando-se o sistema IPG (Immobilized pH Gradient gel strips Amersham Biosciences). As amostras de proteínas provenientes dos experimentos realizados foram separadas utilizando-se as fitas de gradiente de $\mathrm{pH}$ 4,5-5,5 e 3-10. As etapas descritas a seguir foram conduzidas conforme protocolo desenvolvido por Bellato et al. (2003) ${ }^{1}$.

As alíquotas de $75 \mu \mathrm{g}$ de proteínas acondicionadas em tubos eppendorfs provenientes dos tratamentos controle e diferentes doses de metal (3 e $100 \mu \mathrm{M}$ de cádmio) foram ressolubilizadas em uma solução de eletro-focalização composta por $123 \mu \mathrm{L}$ de água ultrapura esterilizada, 9M de uréia, $6 \%$ de chaps (detergente não iônico), 75 mM de DTT, 0,006\% de azul de bromofenol e 0,8\% de anfolina (tampão IPG- Amersham Biosciences para os pH 4,5-5,5 e 3-10, correspondentes as fitas utilizadas), totalizando um volume final de $400 \mu \mathrm{L}$. Nessa solução, as proteínas são desnaturadas e suas pontes dissulfeto reduzidas. Após permanecerem por 30 minutos em temperatura ambiente (aproximadamente $25^{\circ} \mathrm{C}$ ) nessa solução, as proteínas foram centrifugadas a $8000 \mathrm{xg}$ por 2 minutos, visando separar por precipitação as proteínas solúveis 
das insolúveis e demais impurezas. Após a centrifugação, o sobrenadante (proteínas solúveis) foi aplicado em fitas com gradiente de $\mathrm{pH}$ imobilizado linear ( $\mathrm{pH} 4,5-5,5$ ou $3-10,18 \mathrm{~cm}$ ). A reidratação das fitas foi feita a $20^{\circ} \mathrm{C}$ por 9 horas no sistema focalizador IPGphor (Amersham Biosciences). As condições de corrida eletroforética foram $30 \mathrm{~V}-6 \mathrm{hrs}, 150 \mathrm{~V}-1 \mathrm{~h}, 350 \mathrm{~V}-1 \mathrm{~h}, 500 \mathrm{~V}-1 \mathrm{~h}$, $1000 \mathrm{~V}-1 \mathrm{~h}, 3000 \mathrm{~V}-1 \mathrm{~h}$ e $5000 \mathrm{~V}$ até atingir um total de $65000 \mathrm{~V}-\mathrm{h}$ (pH 3-10) e $75000 \mathrm{~V}-\mathrm{h}(\mathrm{pH} 4,5-5,5)$.

A focalização das amostras dos três tratamentos (controle, 3 e $100 \mu \mathrm{M}$ de cádmio) foi feita simultaneamente.

\subsubsection{Equilíbrio da fita}

O equilíbrio da fita de gradiente de $\mathrm{pH}$ possibilita a transição das amostras da primeira para a segunda dimensão, pois confere as proteínas uma carga total negativa e mantém as pontes dissulfeto reduzidas, possibilitando a corrida eletroforética. Nesta etapa, as fitas foram incubadas em duas soluções, a primeira, composta por $6 \mathrm{~mL}$ de $500 \mathrm{mM}$ de Tris- $\mathrm{HCl} \mathrm{pH} 8,4,6 \mathrm{M}$ de uréia, $30 \%$ de glicerol, $2 \%$ de SDS, $2 \%$ de DTT, por 12 minutos; e a segunda, composta por $6 \mathrm{~mL}$ de $500 \mathrm{mM}$ de Tris- $\mathrm{HCl}$ pH 8,4, $6 \mathrm{M}$ de uréia, 30\% de glicerol, $2 \%$ de SDS e $3 \%$ de iodoacetoamida, por 10 minutos.

\subsubsection{Eletroforese em gel de poliacrilamida desnaturante (segunda- dimensão)}

A eletroforese foi realizada em sistema vertical (Protean II XL, Bio-Rad, Hercules, CA, EUA) com gel de poliacrilamida em um gradiente de concentração entre $8 \%$ e $18 \%,(18,5 \times 50 \times 1 \mathrm{~mm})$. Após o equilíbrio da fita de gradiente de $\mathrm{pH}$, esta foi colocada na parte superior do gel de poliacrilamida. Ao lado da fita, foi aplicado um padrão de peso molecular de proteína com intervalo entre 2,5 kDa e 200 kDa (Mark 12, cat. no LC5677, Invitrogen). Em seguida, foi realizada a corrida eletroforética com voltagens fixadas entre 50, 100 e $150 \mathrm{~V}$, a $10^{\circ} \mathrm{C}$, durante 12 horas. 


\subsubsection{Detecção das proteínas contidas no géis de poliacrilamida}

As proteínas separadas nos géis de poliacrilamida foram vizualisadas através da coloração por nitrato de prata (Blum et al., 1987). Os géis foram documentados usando o programa de Sistema de Imagem Digital Flúor-S Multilmager-PC (Bio-Rad).

\subsubsection{Análise das proteínas contidas nos géis de poliacrilamida}

Os géis foram analisados usando o programa Melanie versão 3 (Genebio, Geneva, Suiça). Através desse programa, estimou-se o número total de proteínas solúveis expressas pela cianobactéria nas condições ambientais estabelecidas, os pontos isoelétricos e massas moleculares destas proteínas, assim como seus níveis de expressão. Este último parâmetro foi mensurado pelo programa através da avaliação do volume (densidade ótica e área) das proteínas contidas no gel ("spots"). Os géis contendo as proteínas provenientes dos tratamentos com 3 e $100 \mu \mathrm{M}$ de Cd foram comparados com os géis obtidos usando as amostras do controle (sem adição de cádmio). Os "spots" de proteínas que apresentaram diferenças no volume de 1,5 vez tanto para maior quanto para menor quando comparados com os "spots" correspondentes no gel contendo a amostra controle foram considerados expressos diferencialmente conforme Wilkins et al. (2001). Além da avaliação entre os diferentes tratamentos foi feita a comparação entre os perfis protéicos dos mesmos tratamentos realizados nos dois experimentos para se verificar a reprodutibilidade dos géis. 


\subsubsection{Identificação das proteínas expressas diferencialmente}

\subsubsection{Digestão das proteínas para análise com MALDI-TOF-MS}

Regiões do gel contendo as proteínas diferencialmente expressas e uma região sem proteína (branco) foram extraídas com um bisturi, cortadas em pedaços de aproximadamente $1 \mathrm{~mm}^{3}$, colocadas em tubos eppendorf e armazenadas na temperatura de $4^{\circ} \mathrm{C}$.

Diferentes concentrações (1, 0,5, 0,1 0,05 e 0,01 $\mu \mathrm{g}$ ) de BSA (soro albumina bovina) foram submetidas à corrida eletroforética em gel de poliacrilamida (12\%) e utilizadas como controle positivo para se verificar a eficiência do método de digestão das proteínas e extração dos peptídeos do gel.

As proteínas selecionadas e o branco foram processados no interior do gel (digestão In gel) para posterior identificação utilizando o método de Wilkins et al. (2001) modificado por Paes-Leme (comunicação pessoal). Esse protocolo incluiu:

Remoção da prata: Nesta etapa os pedaços de géis contendo as proteínas foram encobertos e tratados três vezes com $100 \mu \mathrm{L}$ de uma solução de 100 $\mathrm{mM}$ de tiossulfato de sódio e $30 \mathrm{mM}$ de ferricianeto de potássio para a remoção da prata. Em seguida os géis foram lavados três vezes com $500 \mu \mathrm{L}$ de água ultra-pura para a remoção da solução de descoloração.

Redução e alquilação dos resíduos de cisteína das proteínas: Os géis foram tratados com $50 \mu \mathrm{L}$ de uma solução de $100 \mathrm{mM}$ de bicarbonato de amônio e $45 \mathrm{mM}$ de DTT, a $60^{\circ} \mathrm{C}$ por 30 minutos, para a redução das pontes de dissulfeto dos resíduos de cisteína. Em seguida, os géis foram tratados $50 \mu \mathrm{L}$ de uma solução de 100 mM de bicarbonato de amônio e 100 mM de iodoacetoamida, no escuro por 30 minutos, para a alquilação dos resíduos de cisteína. 
Digestão das proteínas: Os géis foram encobertos com $100 \mu \mathrm{L}$ de acetonitrila $100 \%$ durante 10 minutos, e em seguida foram centrifugados em um concentrador a vácuo (Eppendorf concentrator 5301, Hamburg, Alemanha) por 30 minutos para a sua desidratação. Os pedaços de géis desidratados foram encoberto com uma solução contendo $25 \mathrm{mM}$ de bicarbonato de amônio e 12,5 ng. $\mu \mathrm{L}^{-1}$ de tripsina modificada para sequenciamento (cat. $\mathrm{n}^{\circ} 1418475$, Roche, Mannheim, Alemanha) a $37^{\circ} \mathrm{C}$, durante 12 horas.

Extração dos peptídeos originados da digestão: Após a digestão tríptica das proteínas, os peptídeos foram extraídos do gel através de três lavagens com 50 $\mu \mathrm{L}$ de uma solução de $50 \%$ de acetonitrila e 0,1 \% de ácido trifluoracético (TFA).

Dessalinização da solução: A solução contendo os peptídeos foi concentrada no concentrador a vácuo (Eppendorf concentrator 5301) e em seguida ressuspendida em $10 \mu \mathrm{L}$ de $\mathrm{H}_{2} \mathrm{O}$. As microcolunas de Zip-Tip C18 (cat. $\mathrm{n}^{\circ}$ ztc18s096, Millipore, Billerica, MA, EUA) foram equilibradas e utilizadas para dessalinizar as amostras segundo método descrito pelo fabricante.

\subsubsection{Análise das proteínas por MALDI-TOF-MS}

Após a dessalinização das amostras contendo peptídeos, estes foram ressuspendidos em $2 \mu \mathrm{L}$ de uma solução contendo a matriz de ácido $\alpha$-ciano-4hidroxil-cinamico (Sigma-Aldrich, EUA), acetonitrila 50\% e TFA 0,1\%, e aplicadas sobre uma placa metálica. As análises das massas moleculares dos peptídeos originados da digestão das proteínas de interesse foram feitas por MALDI-TOF-MS (espectrometria de massa de ionização a laser com tempo de vôo) no espectrômetro de massa Micromass Maldi micro (Waters, Milford, MA, EUA), no modo refletor.

A calibração externa foi feita utilizando-se uma mistura de padrões de massa molecular de peptídeos, contendo angiotensina I, ACTH e insulina bovina (Mistura de calibração 2, cat. $n^{\circ}$ P2-3143-00, Perseptive Biosystems, Framingham, MA, EUA). Durante a análise de cada amostra, vários 
espectrogramas foram obtidos e a média destes foi armazenada para posterior comparação das massas moleculares desses peptídeos com as de peptídeos depositados em bancos de dados de proteína, visando à identificação das proteínas.

\subsubsection{Busca das proteínas em banco de dados}

A busca para identificação das proteínas de interesse foi realizada usando o banco de dados do National Center for Biotechnology Information (NCBI) através do programa Mascot Wizard (Boston, MA, EUA) disponível no sítio http://www.matrixscience.com/wizard.html. Utilizou-se 0 padrão monoisotópico das massas dos peptídeos dos espectros obtidos. As buscas foram realizadas utilizando dados das entradas de proteínas de bactérias, no intervalo de peso molecular entre 1 e $100 \mathrm{KDa}$, e entre o ponto isoelétrico 3 e 10. O parâmetro de busca selecionado para possível modificação de aminoácidos foi a carbamidometilação da cisteína (produto de reação com iodoacetoamida formado durante o preparo da amostra). A tolerância de erro considerada foi de $150 \mathrm{ppm}$. 


\section{RESULTADOS E DISCUSSÃO}

\subsection{Curva de crescimento da cianobactéria}

A curva de crescimento da cianobactéria Synechococcus leopoliensis PCC7942 determinada no meio de cultura líquido BG-11, na temperatura de $25^{\circ} \mathrm{C}$ e intensidade luminosa de $40 \mu$ moles $\mathrm{m}^{2} \cdot \mathrm{s}^{-1}$, pode ser observada na Figura 1. Esta cultura apresentou uma fase de adaptação de dois dias e a fase logarítmica se estendeu do segundo ao sexto dia. Constatou-se que entre o sexto e oitavo dia ocorreu o período de transição entre a fase logarítmica e estacionária.

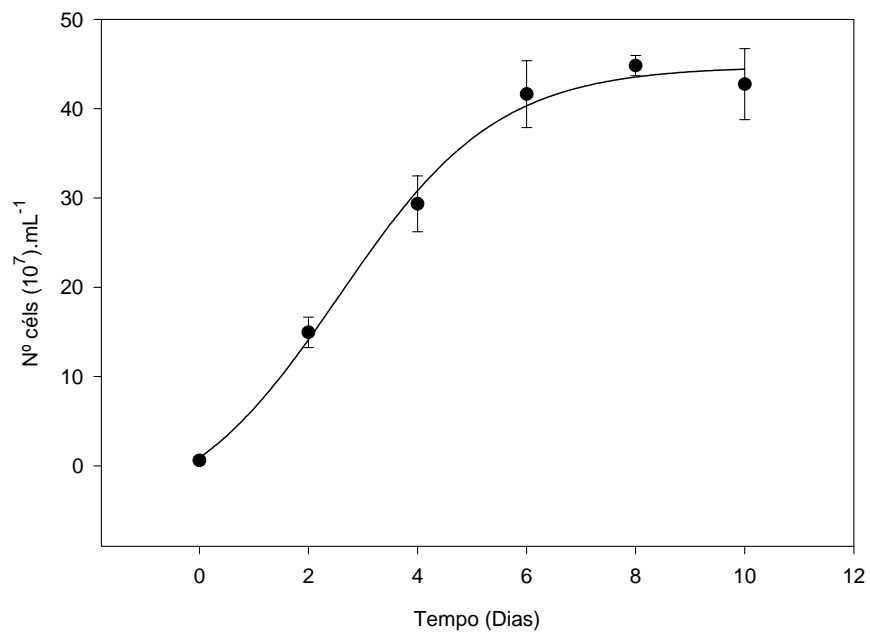

Figura 1 - Curva de crescimento de culturas de S. leopoliensis PCC7942. Nota: os dados são médias de três repetições e desvio padrão. 
Nas condições em que as culturas foram mantidas durante o experimento observou-se um tempo de duplicação de biomassa de 1,6 dias. Em um estudo realizado por Mori et al. (1996), a Synechococcus PCC7942 apresentou um tempo de duplicação menor, ou seja, de 10 horas, porém, as culturas foram mantidas em condições ambientais diferentes $\left(30^{\circ} \mathrm{C}\right.$, com sistema de aeração e $50 \mu$ moles $\mathrm{m}^{-2} \cdot \mathrm{s}^{-1}$ de intensidade luminosa), o que parece ter otimizado o crescimento dessa cianobactéria. No início do estudo aqui apresentado, foram testadas várias condições ambientais visando à otimização do crescimento da linhagem de cianobactéria usada, sendo que a melhor condição obtida foi de intensidade luminosa de $47 \mu$ moles $\mathrm{m}^{-2} \bullet \mathrm{s}^{-1}$, e aeração por agitação constante. Porém, observou-se que essas condições eram favoráveis somente para as culturas crescidas sem o metal e não para as culturas expostas ao $\mathrm{Cd}$, as quais não sobreviviam. Provavelmente, a resposta negativa das culturas expostas ao metal a essa condição ambiental esteja relacionada à ação tóxica que o $\mathrm{Cd}$ exerce sobre o sistema fotossintetizante das cianobactérias, o que foi constatado no estudo de proteoma aqui apresentado, confirmando dados da literatura (Fiore \&Trevors, 1994). 


\subsection{Determinação da dose máxima de Cd tolerável pela Synechococcus leopoliensis PCC7942 e curva de crescimento da cianobactéria na presença de cádmio}

Nos testes de tolerância ao cádmio, onde culturas de Synechococcus elongatus PCC7942 foram submetidas a concentrações de 1, 3 e $5 \mu \mathrm{M} \mathrm{Cd}$, observou-se a sobrevivência das culturas até $3 \mu \mathrm{M}$. Na Figura 2, estão representados as curvas de crescimento de culturas da cianobactéria crescidas na presença das três concentrações de $\mathrm{Cd}$ e na sua ausência (controle). Esse resultado está de acordo com o obtido com a cianobactéria Synechocystis aquatilis, a qual pertencente à mesma ordem (Chroococcales) da Synechococcus (Pawlik \& Skowronski, 1993). Esses autores observaram que a inibição no crescimento da $S$. aquatilis foi provocada por concentrações de cádmio entre 1,1 e 17, $8 \mu \mathrm{M}$, sendo que a $\mathrm{LC}_{50}$ calculada foi de 3,5 $\mu \mathrm{M}$.

Os estudos sobre a tolerância ao Cd de outros gêneros e/ou espécies de cianobactérias, mostraram que existem algumas mais sensíveis ou mais resistentes que a aqui estudada. Por exemplo, a cianobactéria Anabaena variabilis apresentou $\mathrm{LC}_{50}$ de apenas $0,11 \mu \mathrm{M}$ de cádmio (Rachlin et al., 1987), enquanto que a Anabaena 7120 (Laube et al., 1980) e a Spirulina platensis (Rangsayatorn et al., 2002) apresentaram crescimento até nas concentrações $10 \mu \mathrm{M}$ e $87 \mu \mathrm{M}$, respectivamente.

Vários são os fatores a serem considerados em estudos de tolerância a metais, os quais podem interferir nos resultados obtidos, inclusive no estudo aqui apresentado. Sabe-se já há algum tempo que em muitas bactérias os mecanismos de resistência ao metal são conferidos por genes presentes em plasmídeos (Beveridge et al., 1997). Assim, muitas vezes, diferentes linhagens de uma espécie podem ser tolerantes ou sensíveis a um determinado metal, dependendo da presença ou não do plasmídeo na célula. A maior tolerância ao Cd das bactérias S. aureus, B. subtilis, Listeria spp., A. eutrophus, E. coli, P. putida, foi atribuída aos genes presentes em plasmídeos, os quais podem ou não permanecer na população (Beveridge et al., 1997). Sabe-se que a 
cianobactéria aqui estudada (Synechococcus leopoliensis PCC7942) possui dois plasmídeos (Houmard \& Tandeau De Marsac, 1988), mas se estes apresentam genes de resistência a metais ainda permanece por ser esclarecido.

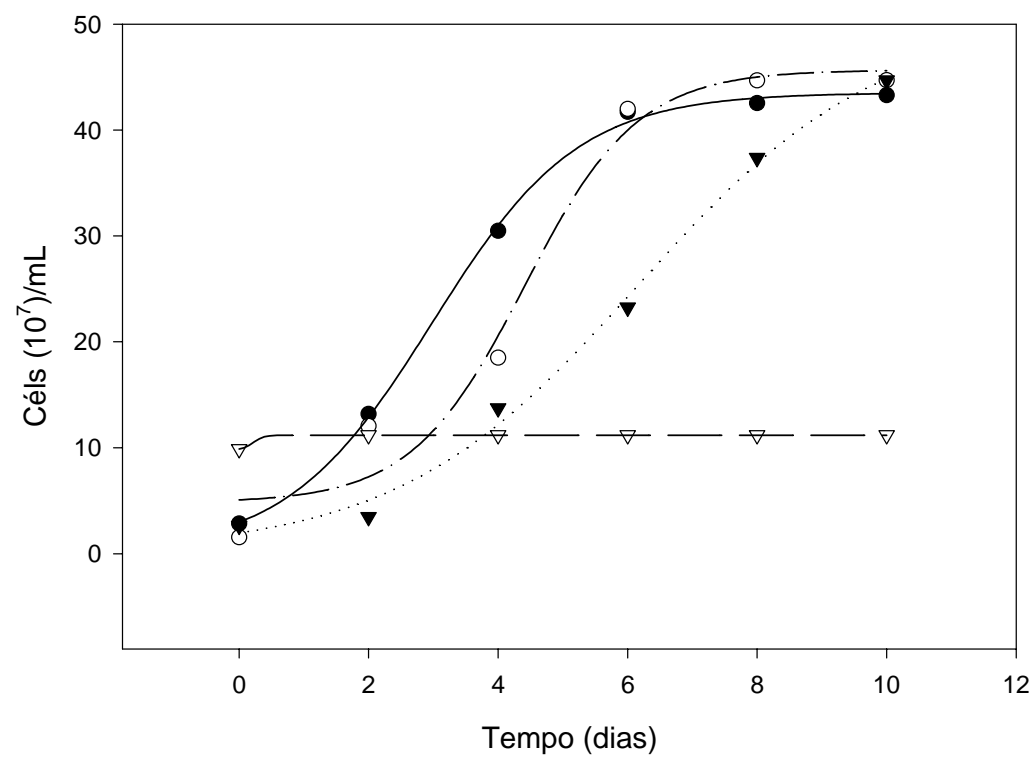

Figura 2 - Curvas de crescimento de culturas S. leopoliensis PCC7942 crescidas na presença de diferentes concentrações de cádmio e na ausência do metal, em condições ambientais controladas.

Nota: os dados são médias de três repetições, e foram originados da conversão dos valores obtidos de densidade ótica para número de células por $\mathrm{mL}$ de meio. 
O mecanismo de tolerância a metal mais descrito em bactérias superresistentes é o efluxo celular (Nies, 2003). Entretanto, esse mecanismo não é interessante do ponto de vista de aplicação biotecnológica com o objetivo de se imobilizar o metal. Assim, torna-se importante o desenvolvimento de um maior número de estudos sobre os mecanismos celulares de responsáveis pelo bioacúmulo.

Outro fator também importante é a especiação do metal no meio de cultura (discutido em mais detalhe no item 4.4). A composição do meio de cultura varia dependendo da espécie microbiana que se está estudando. Muitas vezes, nesses meios são utilizados complexantes de metais os quais torna menos disponível a forma tóxica do metal para a célula. Logo, deve-se levar em conta esses fatores quando se determina a quantidade de metal tolerável pelo microrganismo e quando se faz a comparação entre diferentes espécies.

As culturas crescidas nas concentrações toleráveis de 1 e $3 \mu \mathrm{M}$ de $\mathrm{Cd}$ apresentaram um período de adaptação e tempo de duplicação maiores do que as culturas controles. Observa-se, na Figura 2, que o tempo de adaptação das culturas controles foi de quase dois dias, enquanto que das culturas crescidas em 1 e $3 \mu \mathrm{M}$ foi de aproximadamente 3 e 4 dias, respectivamente. $O$ tempo de geração calculado para as culturas controles (sem metal) foi em média de 1,6 dias, e nas culturas crescidas na presença de 1 e $3 \mu \mathrm{M}$ de $\mathrm{Cd}$ foi em média de 1,72 e 3 dias, respectivamente. Esse comportamento das culturas indica o efeito tóxico do cádmio sobre o seu crescimento, e tem sido relatado em outros estudos sobre a toxidez de metais sobre células bacterianas. Rachlin et al. (1987) observaram que culturas de Anabaena flos-aquae crescidas na presença de 0,11 $\mu \mathrm{M}$ de $\mathrm{Cd}$ apresentaram aumento no tempo de duplicação de 1,95 para 4,51 dias. Aumento no tempo de duplicação de biomassa também foi observado para as cianobactérias Nostoc UAM 208 (Fernandez-Piñas et al., 1991) e Anabaena inaequalis (Stratton \& Corke, 1979) na presença de cádmio e níquel, respectivamente. Conforme já observado anteriormente (item 4.1.), neste experimento também se constatou que entre o sexto e oitavo dia ocorreu o 
período de transição entre a fase logarítmica e estacionária. Experimentos preliminares realizados anteriormente mostraram que nessa fase a cianobactéria foi mais tolerante ao $\mathrm{Cd}$. Dessa forma, esse período foi escolhido para se fazer a adição do Cd nas culturas dos experimentos de proteoma.

O efeito tóxico do cádmio nas células de cianobactéria tem sido atribuído à sua ação sobre o aparelho fotossintético e divisão celular. Husaini et al. (1991) e Gorbunov \& Gorbunova (1992) observaram a ação tóxica do cádmio sobre a atividade fotossintética e de fixação de carbono de Nostoc linckia e Anabaena variabilis. Nos experimentos realizados, o metal afetou a evolução de oxigênio, diminuiu a incorporação de ${ }^{14} \mathrm{C}$ e o conteúdo de ATP, e inibiu a cadeia de transporte de elétrons. Bolãnos et al. (1992) observaram que a presença de Cd nas culturas de Anabaena PCC7119 causou a redução intracelular de $\mathrm{Ca}^{2+}$ e $\mathrm{Mg}^{2+}$. Os autores sugeriram que o cádmio competiu com esses dois cátions por sítios celulares, dessa maneira, interferindo na divisão celular e promovendo uma expansão no tamanho da célula.

\subsection{Curvas de crescimento de culturas na presença da máxima concentração tolerável de cádmio e acúmulo do metal pelas células}

Após a determinação da concentração máxima de cádmio tolerável pela Synechococcus leopoliensis PCC7942, $3 \mu \mathrm{M}$, foram realizados dois experimentos independentes de curva de crescimento da cianobactéria na presença dessa concentração do metal (Figuras 3 e 4) onde se avaliou o acúmulo do cádmio pelas células. Os resultados de crescimento e tempo de duplicação das culturas obtidos nesses dois experimentos foram os mesmos observados para essa dose de Cd no experimento já discutido anteriormente (item 4.2.). 


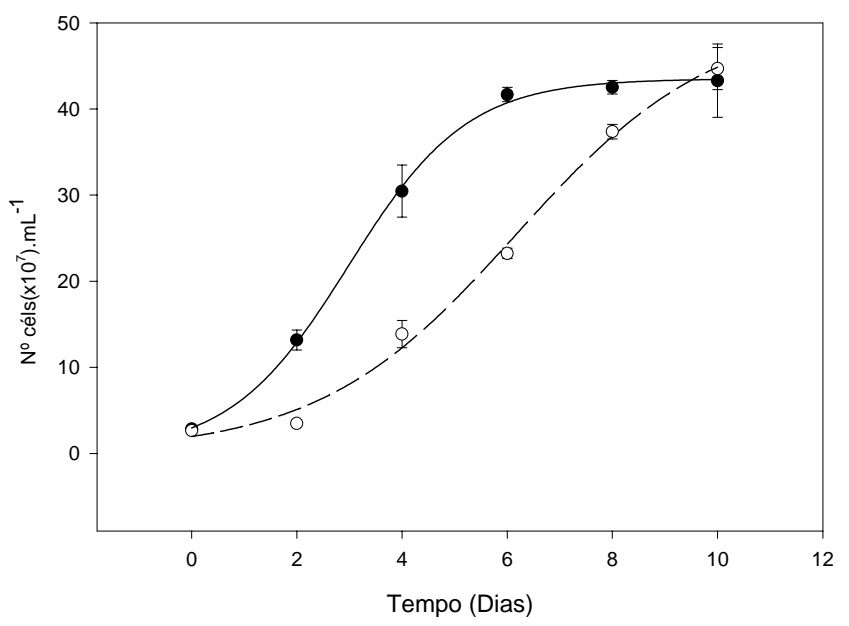

Figura 3 - Curvas de crescimento, do experimento 1 , de culturas de $\mathrm{S}$. leopoliensis PCC7942 crescidas na presença de $3 \mu \mathrm{M}$ de cádmio e na ausência do metal, em condições ambientais controladas.

Nota: os dados são médias de três repetições e desvio padrão, e foram originados da conversão dos valores obtidos de densidade ótica para número de células por $\mathrm{mL}$ de meio.

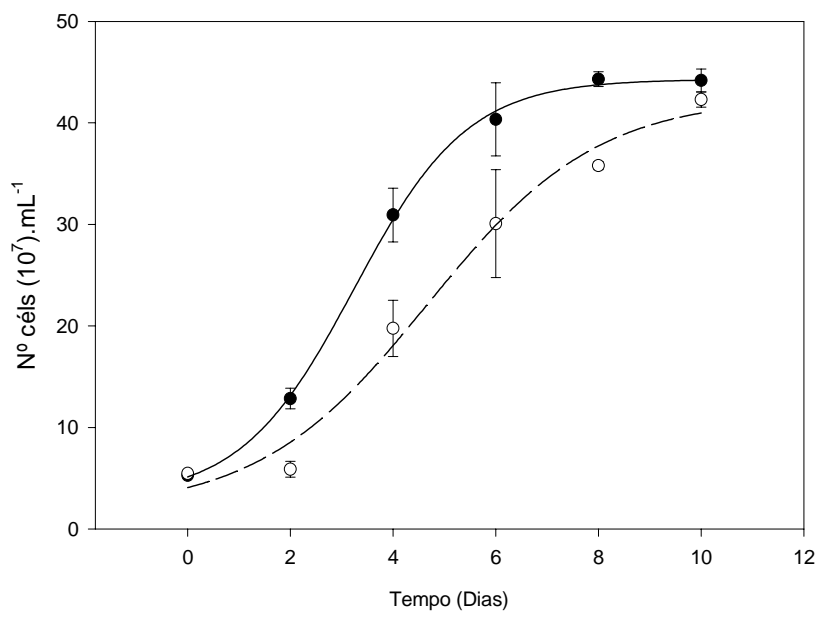

Figura 4 - Curvas de crescimento, do experimento 2, de culturas de S. leopoliensis PCC7942 crescidas na presença de $3 \mu \mathrm{M}$ de cádmio e na ausência do metal, em condições ambientais controladas.

Nota: os dados são médias de três repetições e desvio padrão, e foram originados da conversão dos valores obtidos de densidade ótica para número de células por $\mathrm{mL}$ de meio. 
O maior acúmulo de $\mathrm{Cd}$ pelas células foi observado no início da fase

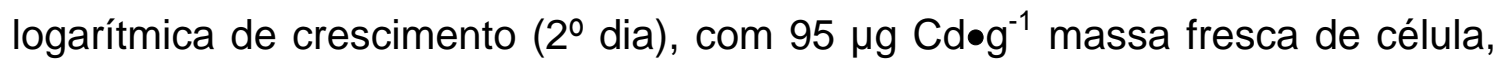
tanto no experimento 1 como no 2 (Figura 5). Houve um pequeno decréscimo durante a fase logarítmica, sendo que no $6^{\circ}$ dia a quantidade de cádmio

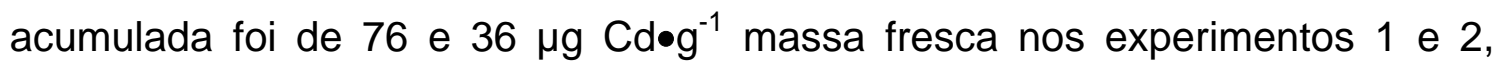
respectivamente. $\mathrm{Na}$ fase estacionária $\left(12^{\circ} \mathrm{dia}\right)$ foram observados os menores

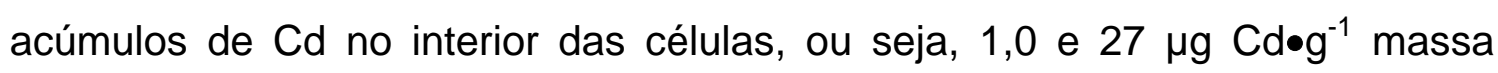
fresca nos experimentos 1 e 2 , respectivamente.

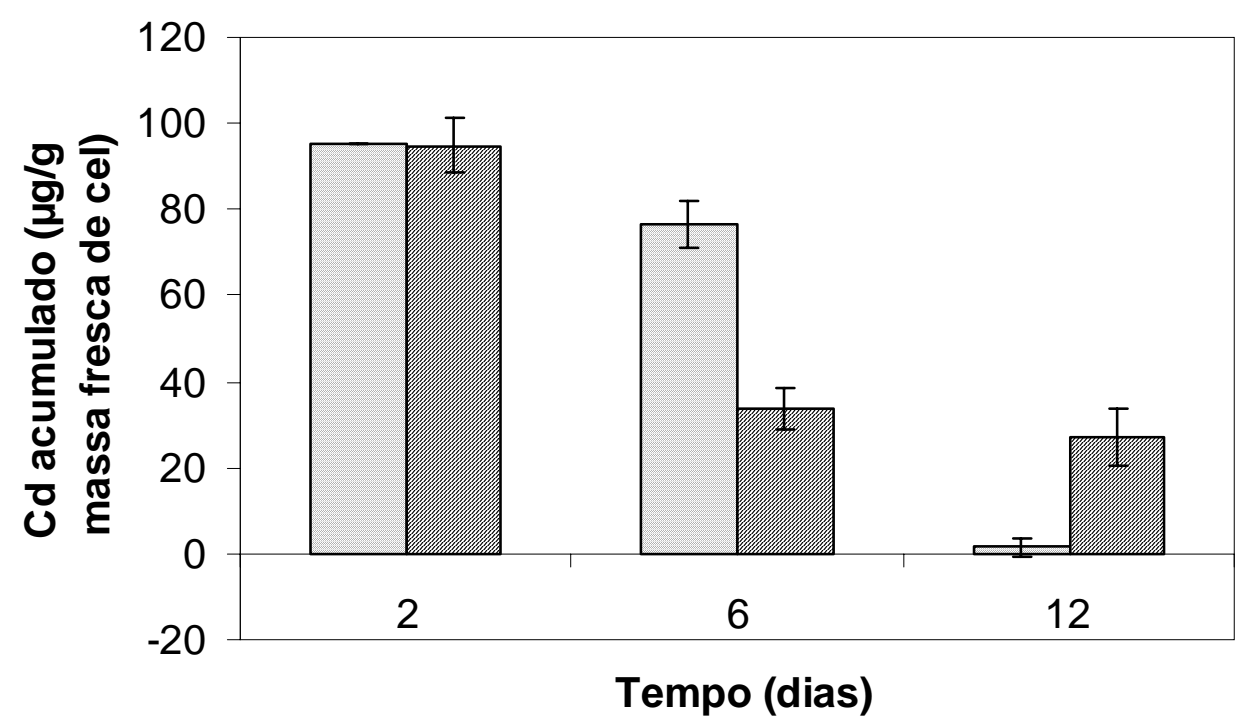

$\square$ Experimento $1 \square$ Experimento 2

Figura 5 - Acúmulo de cádmio pelas células de S. leopoliensis PCC7942, submetidas a $3 \mu \mathrm{M}$ do metal, no início e fim da fase logarítmica de crescimento $\left(2^{\circ}\right.$ e $6^{\circ}$ dias), e na fase estacionária $\left(12^{\circ} \mathrm{dia}\right)$, referentes aos dois experimentos.

Nota: os dados são médias de três repetições e desvio padrão. 
Entretanto, esses resultados não indicam necessariamente que ocorreu um decréscimo na capacidade de acúmulo das células na fase logarítmica, mas sim uma diminuição da disponibilidade do metal para as células, uma vez que a densidade celular aumentou enquanto que a quantidade de cádmio no meio permaneceu constante. Logo, a razão da quantidade de metal por massa fresca foi decrescente durante o desenvolvimento da cultura, conforme mostrado nas Figuras 6 e 7. Esses resultados estão em concordância com os obtidos por Singh \& Yadava (1985) no estudo feito sobre acúmulo de cádmio (1, 5 e $10 \mu \mathrm{M})$ por Anacystis nidulans (também conhecida como Synechococcus PCC7942). Esses autores observaram que o cádmio acumulado por células provenientes de inóculos densos era menor do que de inóculos com poucas células. Isso ocorreu, segundo o autor, porque nas culturas mais densas a disponibilidade de metal por célula era menor.

A capacidade de captura de metais do meio, produzindo uma concentração interna maior do que a externa é observada em um grande número de organismos aquáticos, inclusive em cianobactérias e algas (Vymazal, 1987). O processo de acúmulo envolve duas etapas: uma passiva, onde os íons se aderem ao envoltório celular, e uma ativa, onde há transporte dos íons para o interior da célula. A primeira etapa ocorre rapidamente, sendo relatada a adsorção de cádmio por células de Spirulina platensis (Rangsayatorn et al., 2002) e Anacystis nidulans (Singh \& Yadava, 1985) em apenas 5 minutos, enquanto que o acúmulo intracelular pode ocorrer no período de 30 minutos a 2 horas. Em diversos trabalhos é enfatizada a importância do pH na adsorção dos metais as células, sendo que para cianobactérias a faixa de $\mathrm{pH}$ onde há maior adsorção é entre 7 e 8 (Rangsayatorn et al., 2002; Singh \& Yadava, 1985; Rai et al., 1990). No presente estudo, em todos os experimentos, utilizou-se o meio de cultura BG-11 com pH de 7,4 o que possivelmente favoreceu a adsorção do Cd no envoltório celular. 


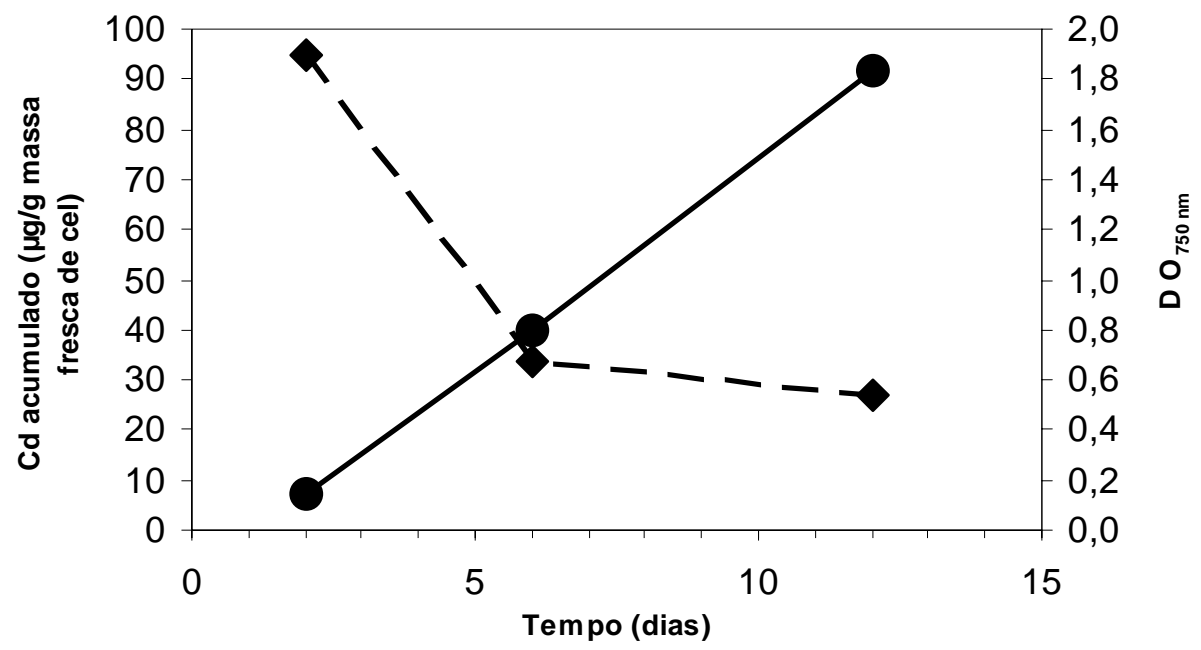

$\multimap \diamond$ Cd acumulado $\longrightarrow$ densidade celular

Figura 6 - Relação entre a quantidade de cádmio acumulado pelas células de S. leopoliensis PCC7942 e a densidade celular das culturas em diferentes épocas $\left(2^{\circ}, 6^{\circ}\right.$ e $12^{\circ}$ dias $)$.

Nota: dados obtidos no experimento 1 de curva de crescimento.

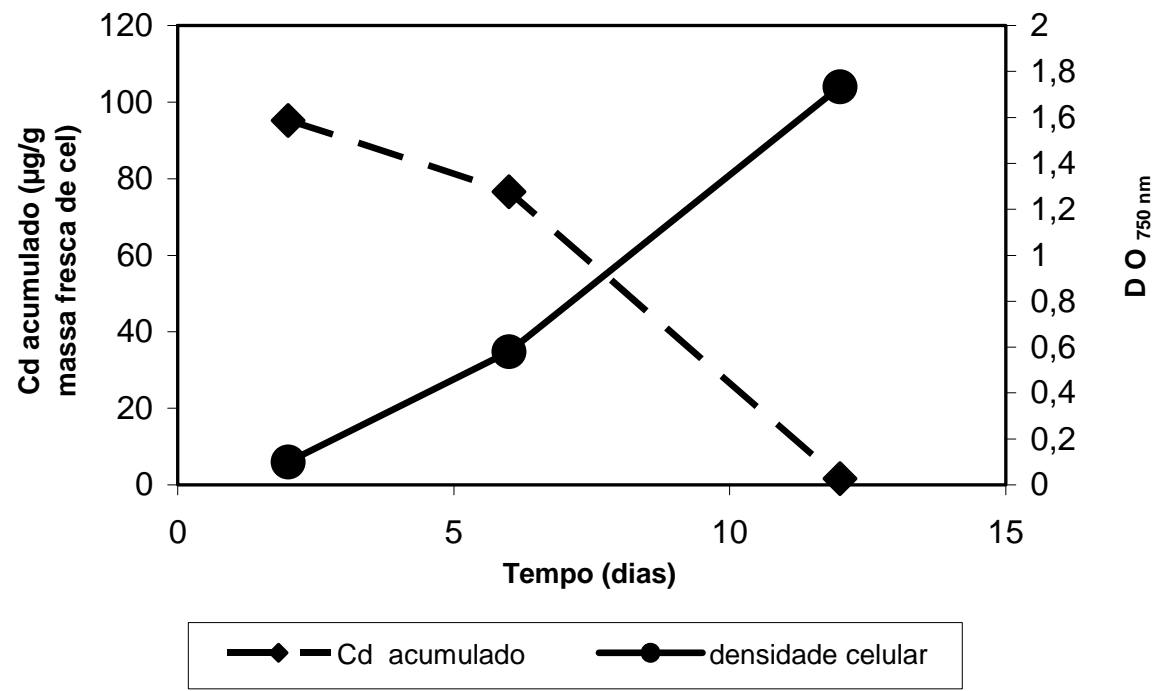

Figura 7 - Relação entre a quantidade de cádmio acumulado pelas células de S. leopoliensis PCC7942 e a densidade celular das culturas em diferentes épocas $\left(2^{\circ}, 6^{\circ}\right.$ e $12^{\circ}$ dias $)$.

Nota: dados obtidos no experimento 2 de curva de crescimento. 
A discrepância dos dados relacionados à quantidade de $\mathrm{Cd}$ acumulada por massa fresca de célula entre os dois experimentos pode ser atribuída a pequenas desigualdades que podem ocorrer em meio de cultura contendo células vivas, pois são muitos os fatores de interferência. Além da quantidade de $\mathrm{Cd}$ adsorvida no envoltório das células que poderia estar variando, este metal poderia estar sendo seqüestrado por proteínas excretadas, células mortas, e possivelmente estar sendo quelado pelos componentes do meio de cultura de forma diferente devido a pequenas variações no $\mathrm{pH}$ do meio. Entretanto, um fato que pode também ter influenciado foi a forma de amostragem das células feita para determinação do acúmulo de $\mathrm{Cd}$. $\mathrm{Na}$ amostragem feita no $2^{\circ}$ dia dos experimentos de curva de crescimento, como o número de células era menor, foram retiradas alíquotas maiores, sendo, portanto, mais representativas o que resultou em valores de $\mathrm{Cd}$ acumulado semelhantes para os dois experimentos. De maneira inversa, como havia mais células nas amostragens do $6^{\circ}$ e $12^{\circ}$ dias, as alíquotas retiradas foram menores e, portanto, menos representativas, o que pode ter sido a causa das discrepâncias dos valores de $\mathrm{Cd}$ acumulado. A retirada do volume total das culturas para a quantificação do metal acumulado poder ser uma opção para a redução de erro na amostragem.

\subsection{Especiação do cádmio em meio BG-11}

A avaliação do comportamento químico do $\mathrm{CdCl}_{2}$ nas concentrações de 1, 3, 5 e 100 $\mu \mathrm{M}$ no meio de cultura BG-11 mostrou que nas doses mais baixas do metal a maior parte do íon $\mathrm{Cd}^{2+}$ está complexado com o EDTA, sendo encontrada quantidades crescentes da forma livre do metal $\left(\mathrm{Cd}^{2+}\right)$ de acordo com o aumento de doses: $8 \%$ em $1 \mu \mathrm{M}, 23 \%$ em $3 \mu \mathrm{M}$ e $43 \%$ em $5 \mu \mathrm{M}$. Na concentração de $100 \mu \mathrm{M}$ a espécie iônica $\mathrm{Cd}^{2+}$ foi mais abundante (75\%) (Figura 8), provavelmente porque quando adicionada uma alta concentração deste metal, ocorre uma saturação dos sítios de ligação do EDTA, e ainda sobra uma grande quantidade de íons de cádmio não ligados. 

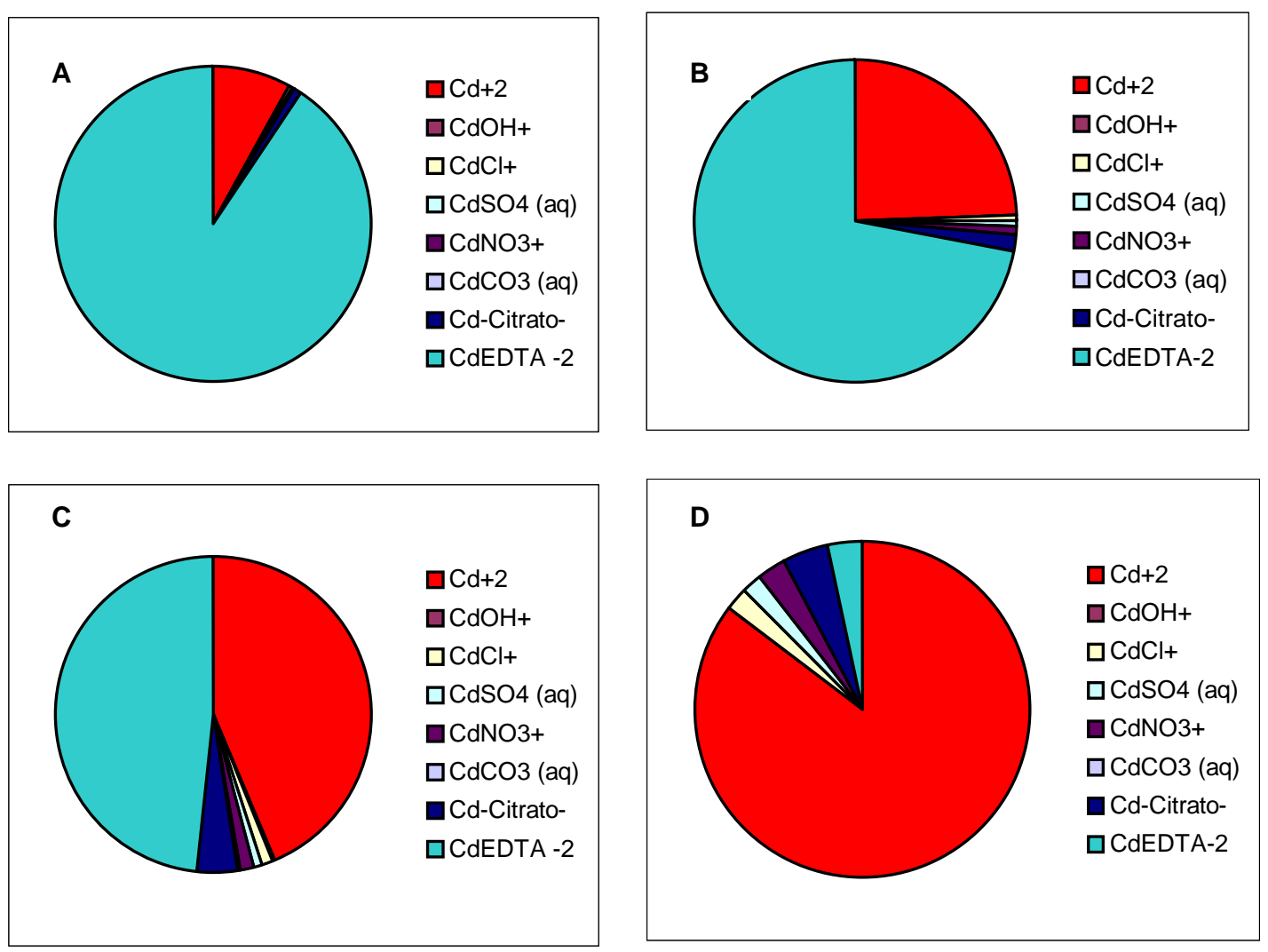

Figura 8 - Especiação do $\mathrm{CdCl}_{2}$ nas concentrações de $1 \mu \mathrm{M}(\mathrm{A}), 3 \mu \mathrm{M}(\mathrm{B}), 5 \mu \mathrm{M}$ (C) e $100 \mu \mathrm{M}(\mathrm{D})$ no meio de cultura BG-11 calculada utilizando-se 0 programa Visual MINTEQ versão 2.23.

Assim, o programa MINTEQ possibilitou estimar a quantidade da forma livre do cádmio no meio de cultura BG-11, ou seja, 0,08 $\mu \mathrm{M}, 0,69 \mu \mathrm{M}, 2,15 \mu \mathrm{M}$ e $75 \mu \mathrm{M}$ quando adicionadas as concentrações 1, 3, 5 e 100 $\mu \mathrm{M}$ de $\mathrm{CdCl}_{2}$. Nessa avaliação, foram considerados apenas as interações do cádmio com os componentes do meio de cultura, porém, as células também podem interferir no processo de especiação do cádmio. De acordo com Foster \& Morel (1982) a forma mais tóxica do cádmio é a $\mathrm{Cd}^{2+}$. Vários (Fernandez-Piñas et al., 1991; Singh \& Yadava, 1985; Singh \& Pandey, 1981), afirmam, também, que quando estão presentes no meio agentes complexantes de metais, sintéticos (EDTA, NTA, ácido cítrico e Tris) ou naturais, observa-se a diminuição da biodisponibilidade de $\mathrm{Cd}^{2+}$ e conseqüentemente, também a toxidez do metal. 
Ainda existem discussões sobre as formas tóxicas dos metais e se as formas complexadas com compostos orgânicos, como o EDTA realmente, são menos disponíveis e tóxicos para a célula. No presente estudo, se for considerado que a forma mais tóxica é $\mathrm{o} \mathrm{Cd}^{2+}$, pode-se supor que a concentração de 0,69 $\mu \mathrm{M}$ de Cd é a quantidade máxima tolerada pelas células de S. leopoliensis PCC7942.

\subsection{Estudo comparativo de proteomas de Synechococcus leopoliensis PCC7942 em resposta ao cádmio}

Os resultados de acúmulo de Cd pelas culturas utilizadas nos dois experimentos de análise comparativa de expressão de proteínas, as quais foram expostas ao $\mathrm{Cd}$ durante 1 hora estão apresentados na Figura 9. A quantidade de cádmio acumulada nos dois experimentos foi em média 15 e 30

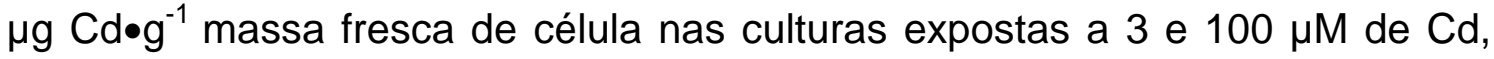
respectivamente. Como pode ser observado, foram encontradas pequenas quantidades de $\mathrm{Cd}$ nas amostras controles o que, provavelmente, foi devido à contaminação proveniente da vidraria e/ou dos reagentes utilizados.

$\mathrm{O}$ acúmulo de $\mathrm{Cd}$ pelas células, as quais estavam no final da fase logarítmica de crescimento, foi proporcional à quantidade do metal no meio de cultura, ou seja, células expostas a $100 \mu \mathrm{M}$ de Cd acumularam duas vezes mais o metal do que as células expostas a $3 \mu \mathrm{M}$ de $\mathrm{Cd}$.

A Figura 10 apresenta os perfis das proteínas de Synechococcus leopoliensis PCC7942 expressas nos tratamentos com duas doses de Cd (3 e $100 \mu \mathrm{M})$ e no controle, separadas através da técnica de eletroforese bidimensional, dentro de um intervalo de $\mathrm{pH}$ entre 3 e 10. Conforme o esperado, observa-se que os três géis apresentaram perfis protéicos semelhantes. As proteínas expressas pela cianobactéria concentram-se no lado esquerdo do gel, o qual corresponde ao intervalo de $\mathrm{pH}$ ácido da fita usada na primeira dimensão, ou seja, a maioria das proteínas desta cianobactéria tem o seu ponto isoelétrico (pl) ácido, entre 4 e 6. 


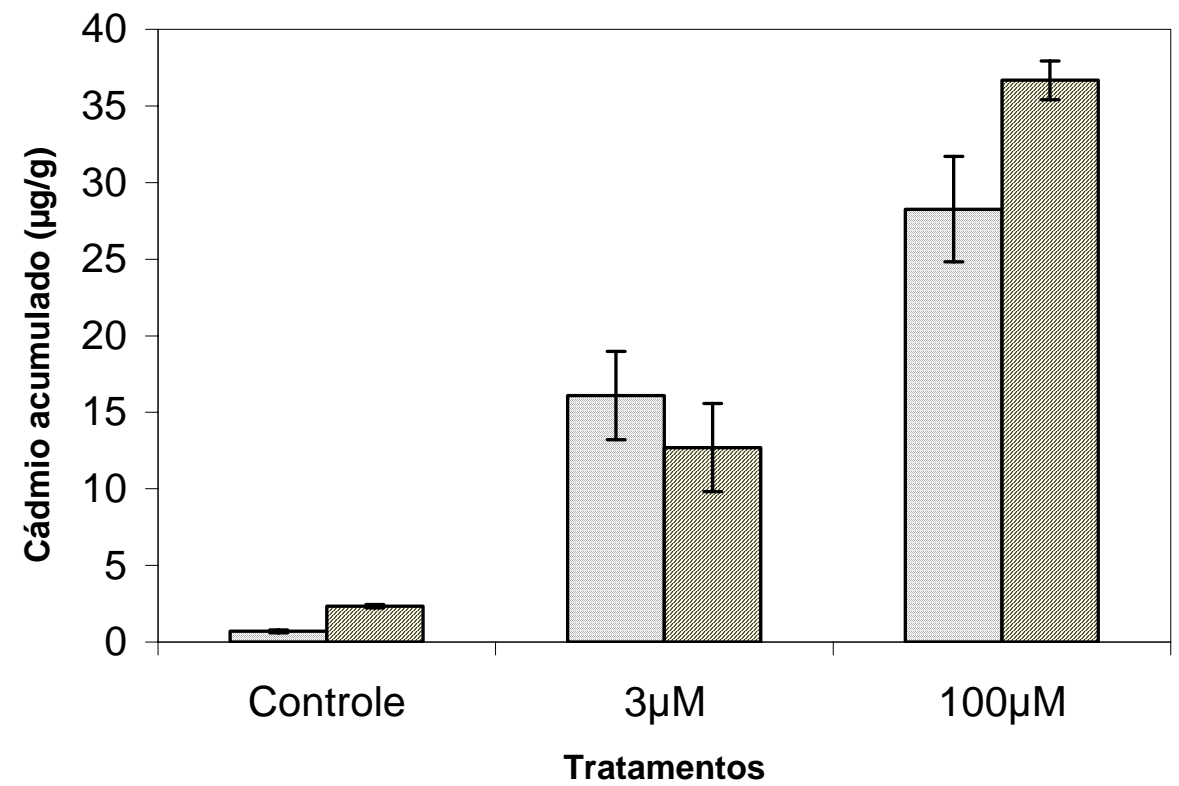

पExperimento 1 axperimento 2

Figura 9 - Acúmulo de cádmio pelas células de S. leopoliensis PCC7942 submetidas a 3 e $100 \mu \mathrm{M}$ do metal, durante uma hora, utilizadas no estudo de expressão diferencial de proteínas, nos experimentos 1 e 2.

Este perfil eletroforético é semelhante ao apresentado pela Synechocystis sp. PCC6803, a qual teve suas proteínas extraídas e separadas numa faixa de $\mathrm{pH}$ entre 3 e 10 nos estudos de proteômica realizados por Simon et al. (2002) e Sazuka \& Ohara (1997). Observa-se, também, a ocorrência de várias proteínas com o mesmo peso molecular e diferente pontos isoelétricos, provavelmente, isoformas. No estudo sobre proteínas solúveis de Synechocystis sp. PCC6803, Simon et al. (2002) relatou que 18\% das proteínas identificadas eram isoformas, incluindo as sub-unidades da ficocianina, a ribulose-1,5-bifosfato e a ATP sintase. A presença de isoformas foi também observada nos trabalhos de proteoma de Synechocystis sp. PCC6803 dos autores Sazuka \& Ohara (1997), Huang et al. (2002) e William et al. (2002). 


\section{$\mathrm{PM} / \mathrm{pl}$}

3

103

103

10

92 kDa
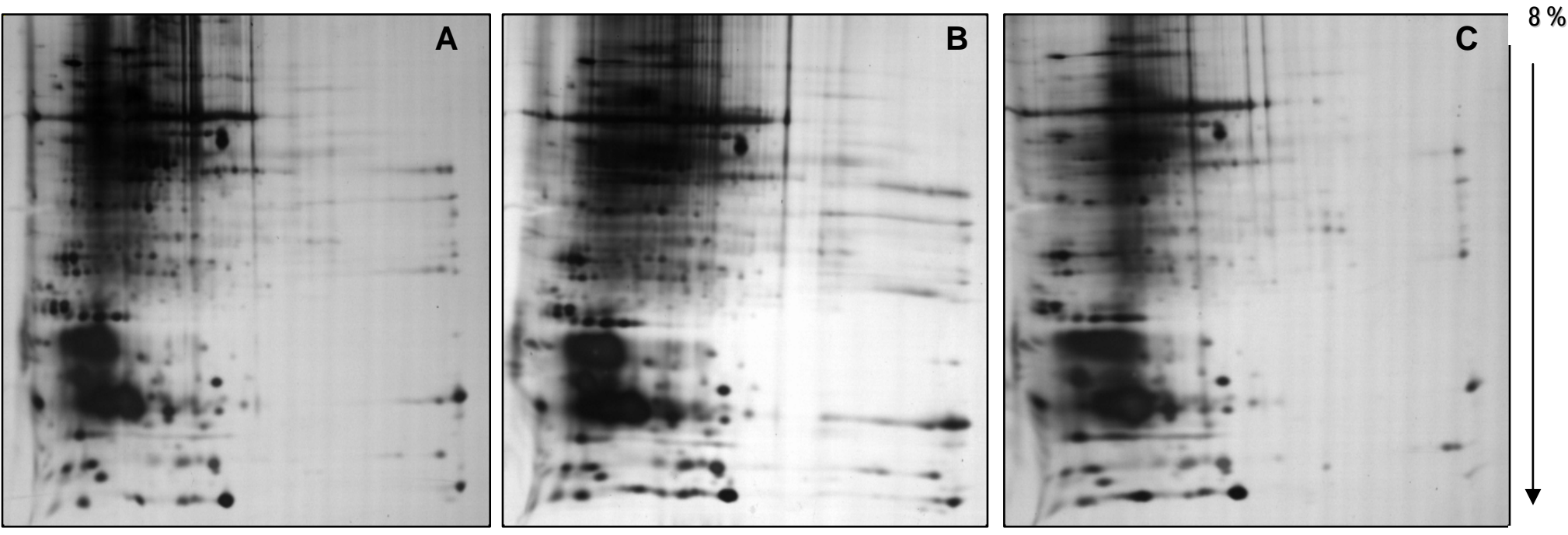

$18 \%$

Figura 10 - Perfis protéicos de S. leopoliensis PCC7942 em um gradiente de pH entre 3 e 10 na primeira dimensão e gradiente de poliacrilamida de 8 a $18 \%$ na segunda dimensão.

A: proteínas expressas pela cianobactéria na ausência do Cd (controle).

$\mathrm{B}$ : proteínas expressas pela cianobactéria exposta a $3 \mu \mathrm{M}$ de Cd durante 1 hora.

C: proteínas expressas pela cianobactéria exposta a $100 \mu \mathrm{M}$ de $\mathrm{Cd}$ durante 1 hora. 
Devido a concentração de proteínas na faixa ácida do gel bidimensional, foram utilizadas as fitas com gradiente de $\mathrm{pH}$ imobilizado nos intervalos de pH entre 4,5 e 5,5, para uma melhor separação e visualização das proteínas. Na Figura 11, estão demonstrados os perfis protéicos, nesta faixa de $\mathrm{pH}$, do controle e do tratamento com $3 \mu \mathrm{M}$ de cádmio. Conforme pode ser observado, os géis apresentaram faixas escuras verticais as quais dificultaram a visualização de algumas proteínas. Wang et al. (2000) relatam que o tratamento dos extratos celulares de Synechocystis sp. PCC6803 com uréia e detergente aumentou a quantidade de proteínas na amostra, mas também, de pigmentos e outros componentes lipo-solúveis que interferiram na visualização das proteínas no gel. No estudo aqui apresentado foram realizados experimentos anteriores onde o tratamento das amostras para a remoção de impurezas através de precipitação foi utilizado, porém, observou-se uma diminuição no número e quantidade de proteínas no gel. Logo, optou-se pelo tratamento das amostras usando apenas ultra-centrifugação e a análise do gel foi feita apenas com aquelas proteínas facilmente visualizadas.

A exposição ao $\mathrm{Cd}$ das células durante 1 hora foi escolhida para se observar à expressão de proteínas, uma vez que o interesse era detectar as primeiras proteínas a serem afetadas pelo metal e não àquelas provenientes de respostas de efeitos secundários da célula. No trabalho realizado por Ybarra \& Webb (1999) culturas de Synechococcus sp. PCC7942 tratadas com $100 \mu \mathrm{M}$ de cádmio em diferentes intervalos de tempo tiveram a expressão do RNA mensageiro de dois genes expressos em condições de estresse (groEL e $s m t A$ ) analisada. Esses autores constataram que a quantidade de RNAm da groEL e da $s m t A$, na célula, foi maior após 15 e 60 minutos, respectivamente, de exposição da cultura ao metal. 


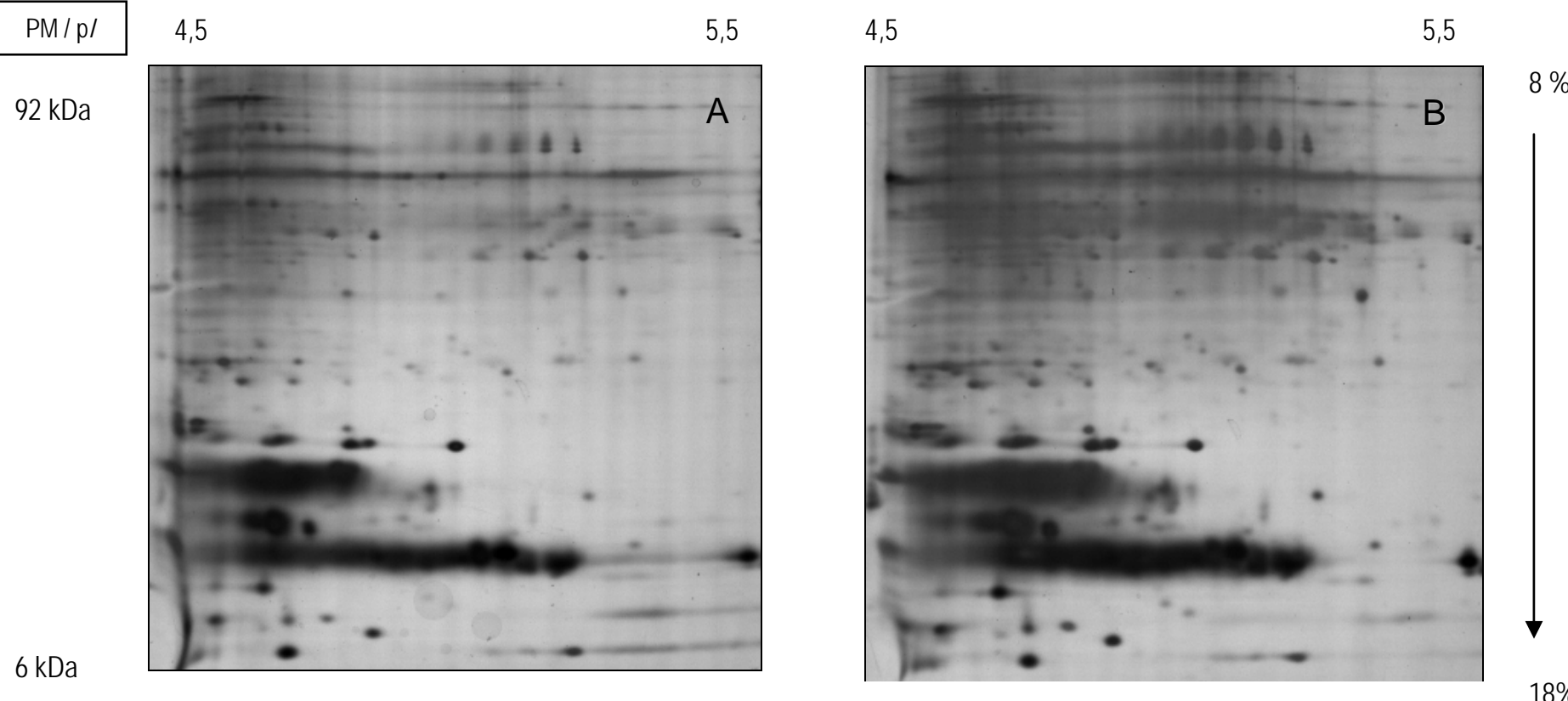

Figura 11 - Perfis protéicos de S. leopoliensis PCC7942 em um gradiente de pH entre 4,5 e 5,5 na primeira dimensão e gradiente de poliacrilamida de 8 a $18 \%$ na segunda dimensão.

A: proteínas expressas pela cianobactéria na ausência do Cd (controle).

B: proteínas expressas pela cianobactéria exposta por 1 hora a $3 \mu \mathrm{M}$ de Cd. 
O tratamento das células com uma concentração tolerável de metal (3 $\mu \mathrm{M})$ e de uma concentração alta e letal $(100 \mu \mathrm{M})$ resultou em padrões de expressão protéica diferenciados. O número de proteínas que tiveram a expressão induzida (I) nesses dois tratamentos foi o mesmo, ou seja, duas proteínas, mas a diferença ocorreu no número de proteínas reprimidas $(R)$, o qual foi maior no tratamento com $100 \mu \mathrm{M}$ (20 proteínas) do que no tratamento com $3 \mu \mathrm{M}$ (11 proteínas) (Figura 12). As proteínas reprimidas e induzidas nos dois tratamentos estão listadas na Tabela 1 e indicadas nas Figuras 14 a 19.

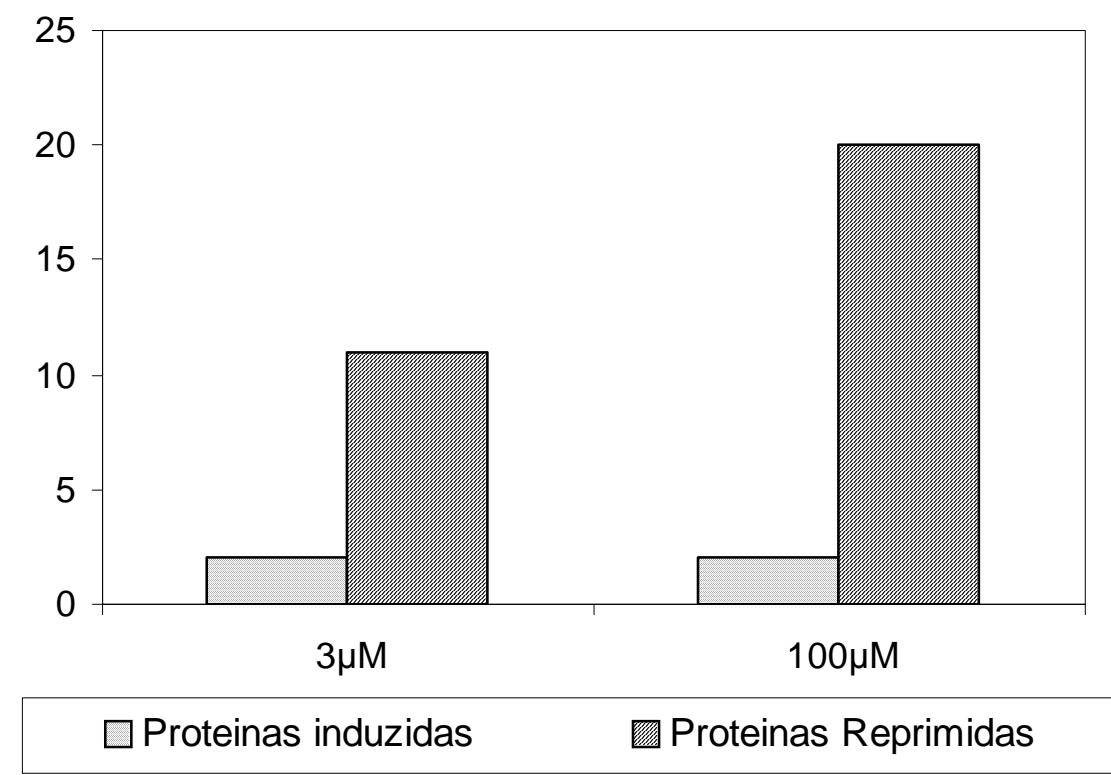

Figura 12 - Proteínas de S. leopoliensis PCC7942 expressas diferencialmente após exposição a 3 e $100 \mu \mathrm{M}$ de Cd, durante 1 hora.

As duas proteínas induzidas tanto no tratamento com $3 \mu \mathrm{M}$ de $\mathrm{Cd}$ como no de $100 \mu \mathrm{M}$ não foram às mesmas (Figura 13). As proteínas induzidas na presença de $3 \mu \mathrm{M}$ de $\mathrm{Cd}$ apresentaram peso molecular de $16 \mathrm{kDa}$ e ponto isoelétrico 8,2, e $6 \mathrm{kDa}$ e p/8,23, ambas tiveram sua expressão aumentada próximo a duas vezes e meia em relação ao controle (Tabela 1; Figura 19, proteínas 12 e 13). As proteínas induzidas na presença de $100 \mu \mathrm{M}$ de Cd 
apresentam peso molecular de 7 kDa e p/ 5,13 (Tabela 1; Figura 14, proteína 14) e 32 kDa e p/ 6,8 (Tabela 1; Figura 18, proteína 30) , ambas tiveram sua expressão aumentada próximo a duas vezes em relação ao controle.

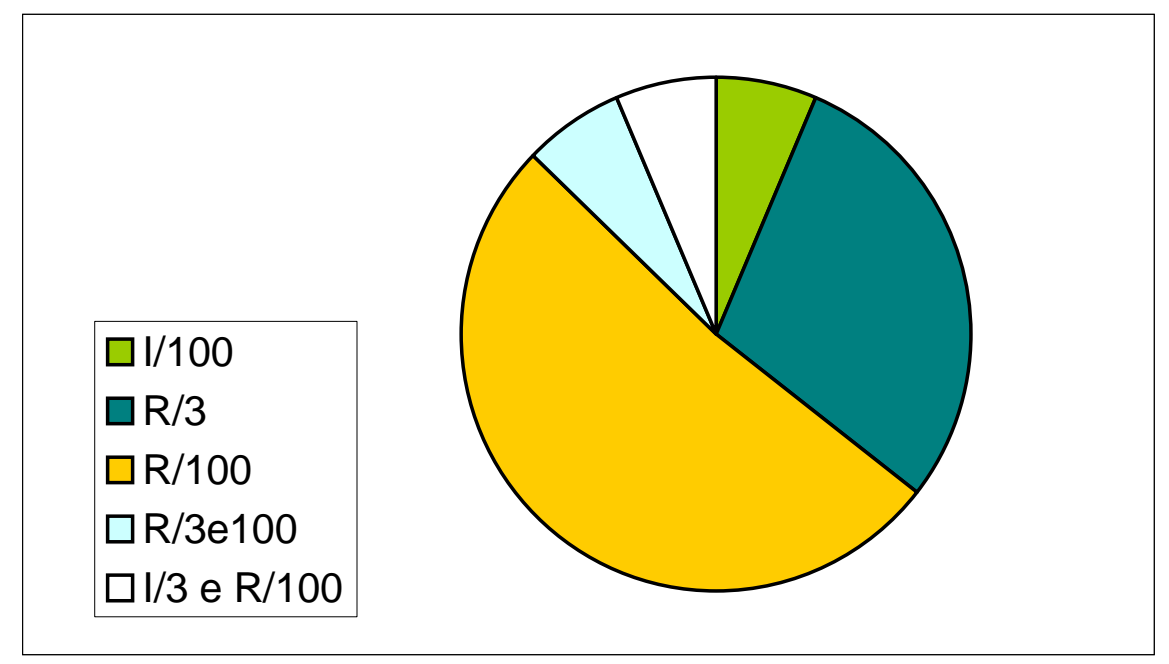

Figura 13 - Proteínas da S. leopoliensis PCCC7942 expressas diferencialmente após exposição a 3 e $100 \mu \mathrm{M}$ de Cd, durante 1 hora.

1/100: proteínas induzidas em $100 \mu \mathrm{M}$ de Cd.

$\mathrm{R} / 3$ : proteínas reprimidas em $3 \mu \mathrm{M}$ de $\mathrm{Cd}$.

R/100: proteínas reprimidas em $100 \mu \mathrm{M}$ de Cd.

$\mathrm{R} / 3$ e 100: proteínas reprimidas em 3 e $100 \mu \mathrm{M}$ de $\mathrm{Cd}$.

I/3 e R/100: proteínas induzidas em $3 \mu \mathrm{M}$ de Cd e reprimidas em $100 \mu \mathrm{M}$ de Cd.

Na Figura 13 observa-se também que o número de proteínas em comum reprimidas em 3 e $100 \mu \mathrm{M}$ de $\mathrm{Cd}$ foi pequeno (duas proteínas) comparando-se ao número de proteínas expressas exclusivamente em cada tratamento (9 proteínas em $3 \mu \mathrm{M}$ de Cd, e 16 proteínas em $100 \mu \mathrm{M}$ de Cd). Além disso, as duas proteínas que foram induzidas em $100 \mu \mathrm{M}$ de Cd não tiveram expressão diferencial em $3 \mu \mathrm{M}$, enquanto que as duas proteínas induzidas em 3 $\mu \mathrm{M}$ de $\mathrm{Cd}$ foram reprimidas em $100 \mu \mathrm{M}$. 
Tabela 1. Proteínas expressas diferencialmente pela S. leopoliensis PCC7942 exposta a 3 e $100 \mu \mathrm{M}$ de cádmio durante 1 hora.

\begin{tabular}{|c|c|c|c|c|c|c|c|}
\hline \multirow[b]{2}{*}{ Proteína } & \multicolumn{3}{|c|}{$3 \mu \mathrm{M} \mathrm{Cd}$} & \multicolumn{2}{|r|}{$100 \mu \mathrm{M} \mathrm{Cd}$} & \multirow[b]{2}{*}{ MMA (kDa) } & \multirow[b]{2}{*}{$\mathrm{pl}$} \\
\hline & $\mathrm{I} / \mathrm{R}$ & $\Delta$ Volume & $\mathrm{s}$ & I/R & $\Delta$ Volume & & \\
\hline 1 & $\mathrm{R}$ & 1,51 & 0,13 & - & - & 10 & 4,60 \\
\hline 2 & $\mathrm{R}$ & 1,56 & 0,11 & - & - & 20 & 5,23 \\
\hline 3 & $\mathrm{R}$ & 1,54 & 0,02 & - & - & 25 & 4,65 \\
\hline 4 & $\mathrm{R}$ & 1,65 & 0,18 & - & - & 26 & 4,49 \\
\hline 5 & $\mathrm{R}$ & 1,59 & 0,1 & - & - & 27 & 4,49 \\
\hline 6 & $\mathrm{R}$ & 2,1 & 1,09 & - & - & 27 & 4,40 \\
\hline 7 & $\mathrm{R}$ & 2,12 & 0,86 & - & - & 26 & 4,40 \\
\hline 8 & $\mathrm{R}$ & 1,54 & 0,22 & - & - & 31 & 4,60 \\
\hline 9 & $\mathrm{R}$ & 1,6 & 0,24 & $\mathrm{R}$ & 1,68 & 29 & 4,38 \\
\hline 10 & $\mathrm{R}$ & 1,5 & 0,18 & $\mathrm{R}$ & 1,62 & 62 & 6,12 \\
\hline 11 & $\mathrm{R}$ & 1,5 & 0,25 & & & 10 & 5,89 \\
\hline 12 & I & 1,62 & 0,38 & $\mathrm{R}$ & 2,30 & 16 & 8,20 \\
\hline 13 & I & 1,77 & 0,74 & $\mathrm{R}^{*}$ & & 6 & 8,23 \\
\hline 14 & - & - & - & I & 2,28 & 7 & 5,13 \\
\hline 15 & - & - & - & $\mathrm{R}$ & 1,50 & 10 & 4,47 \\
\hline 16 & - & - & - & $\mathrm{R}$ & 1,55 & 7 & 5,35 \\
\hline 17 & - & - & - & $R^{*}$ & & 16 & 7,98 \\
\hline 18 & - & - & - & $\mathrm{R}$ & 1,64 & 26 & 4,49 \\
\hline 19 & - & - & - & $\mathrm{R}$ & 2,13 & 26 & 4,71 \\
\hline 20 & - & - & - & $\mathrm{R}$ & 2,05 & 31 & 4,63 \\
\hline 21 & - & - & - & $\mathrm{R}^{*}$ & & 31 & 4,55 \\
\hline 22 & - & - & - & $R^{*}$ & & 31 & 4,48 \\
\hline 23 & - & - & - & $\mathrm{R}$ & 1,68 & 16 & 5,58 \\
\hline 24 & - & - & - & $\mathrm{R}$ & 2,37 & 97 & 4,60 \\
\hline 25 & - & - & - & $\mathrm{R}^{*}$ & & 84 & 4,43 \\
\hline 26 & - & - & - & $\mathrm{R}$ & 1,60 & 26 & 5,57 \\
\hline 27 & - & - & - & $\mathrm{R}$ & 2,98 & 29 & 5,71 \\
\hline 28 & - & - & - & $\mathrm{R}$ & 1,50 & 33 & 5,74 \\
\hline 29 & - & - & - & $\mathrm{R}$ & 1,93 & 47 & 5,65 \\
\hline 30 & - & - & - & I & 2,09 & 32 & 6,87 \\
\hline
\end{tabular}

R: proteína reprimida.

I: proteína induzida.

$\Delta$ Volume: valor referente a quantas vezes a proteína foi reprimida ou induzida nos tratamentos com metal em relação ao controle (os dados do tratamento com $3 \mu \mathrm{M}$ de Cd são resultantes da média de dois experimentos independentes e os dados do tratamento com $100 \mu \mathrm{M}$ são provenientes de apenas 1 experimento).

$\mathrm{s}$ : desvio padrão das médias dos valores provenientes dos dois experimentos.

MMA: massa molecular aparente.

$\mathrm{pl}$ : ponto isoelétrico.

* Proteína totalmente reprimida. 


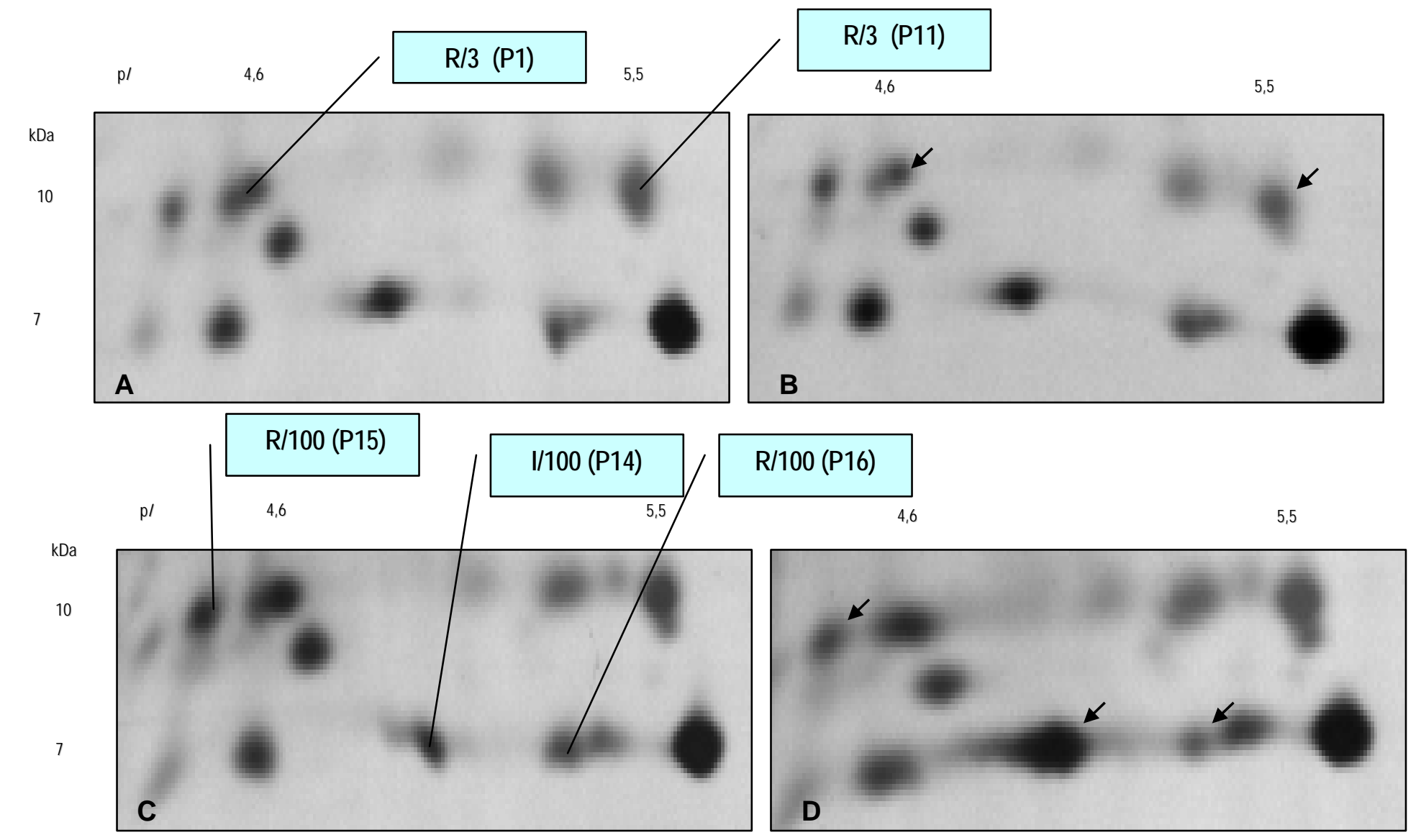

Figura 14 - Imagens detalhadas de proteínas de S. leopoliensis PCC7942 com expressão diferencial causada pela presença do $\mathrm{Cd}$, separadas em gel bidimensional $(\mathrm{pH} 3-10)$.

A e C: controles.

B: tratamento com $3 \mu \mathrm{M}$ de Cd por 1 hora.

D: tratamento com $100 \mu \mathrm{M}$ de Cd por 1 hora.
R/3: proteínas com expressão reprimida em $3 \mu \mathrm{M}$ de $\mathrm{Cd}$. R/100: proteínas com expressão reprimida em $100 \mu \mathrm{M}$ de Cd. I/100: proteínas com expressão induzida em $100 \mu \mathrm{M}$ de Cd. 


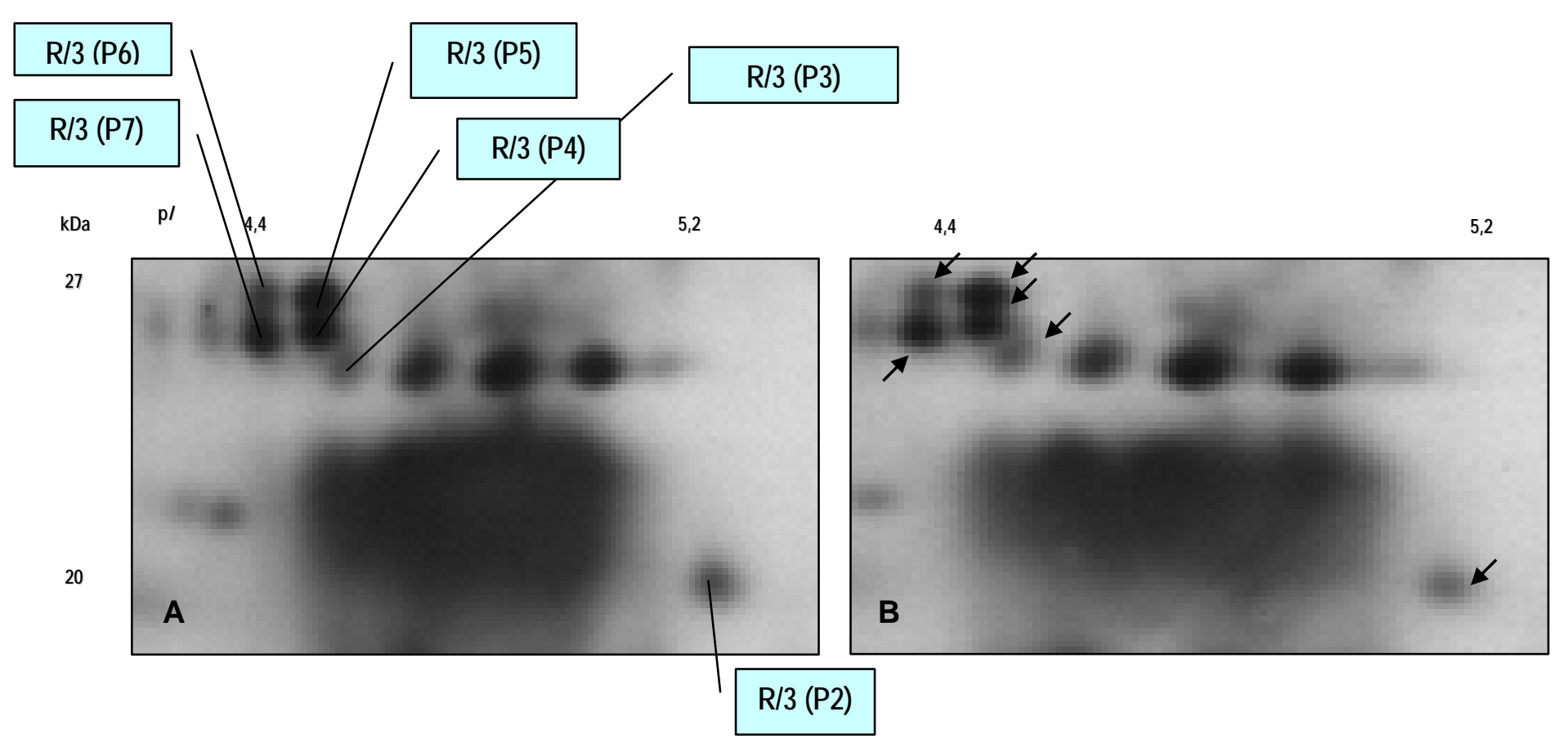

Figura 15 - Imagens detalhadas de proteínas de S. leopoliensis PCC7942 com expressão diferencial causada pela presença do $\mathrm{Cd}$, separadas em gel bidimensional $(\mathrm{pH} 3-10)$.

A: controle.

B: tratamento com $3 \mu \mathrm{M}$ de Cd por 1 hora.

R/3: proteínas com expressão reprimida em $3 \mu \mathrm{M}$ de Cd. 


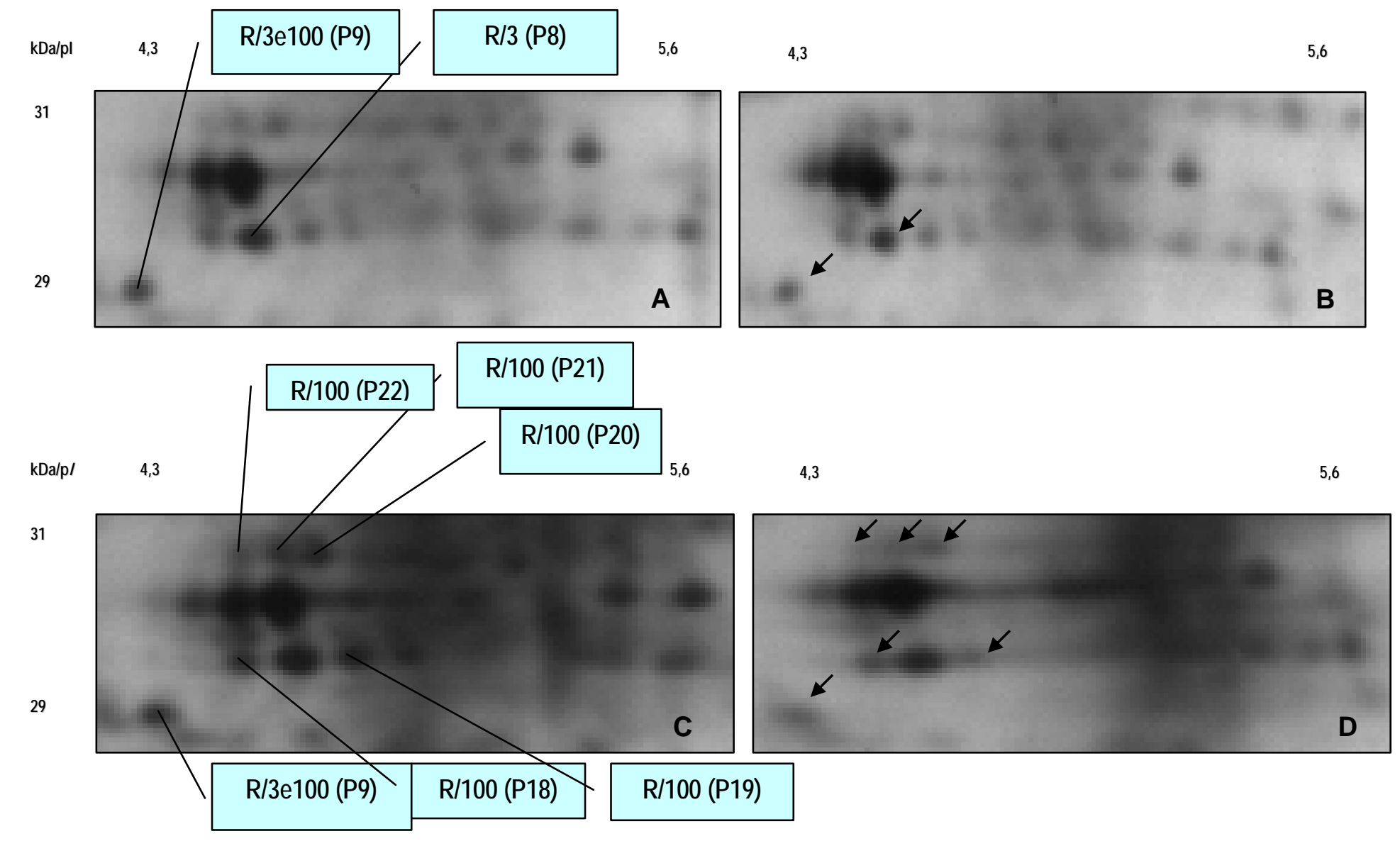

Figura 16 - Imagens detalhadas de proteínas de S. leopoliensis PCC7942 com expressão diferencial causada pela presença de $\mathrm{Cd}$, separadas em gel bidimensional $(\mathrm{pH} 3-10)$.

A e C: controles.

B: tratamento com $3 \mu \mathrm{M}$ de Cd por 1 hora.

$\mathrm{D}$ : tratamento com $100 \mu \mathrm{M}$ de Cd por 1 hora.
$\mathrm{R} / 3$ : proteínas com expressão reprimida em $3 \mu \mathrm{M}$ de cádmio.

R/3 e 100: proteínas com expressão reprimida em 3 e $100 \mu \mathrm{M}$ de cádmio. R/100: proteínas com expressão reprimida em $100 \mu \mathrm{M}$ de cádmio. 
6,1

62

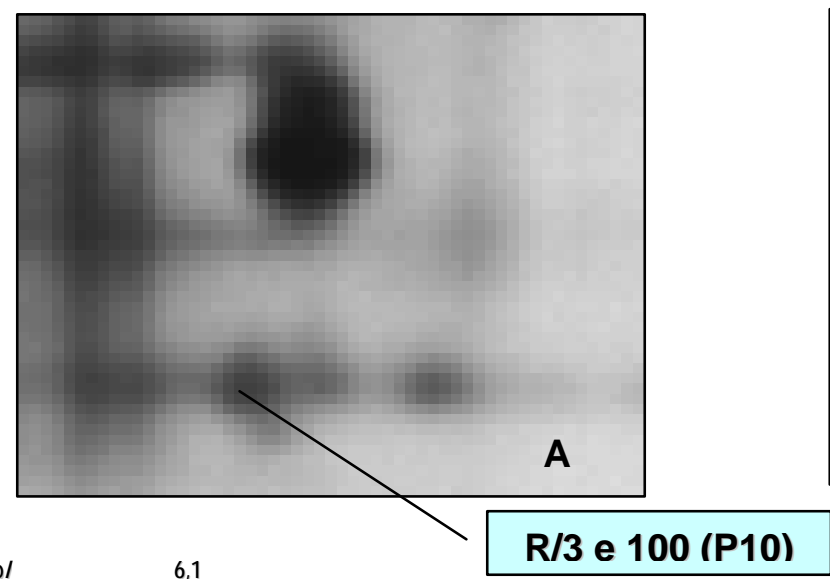

62

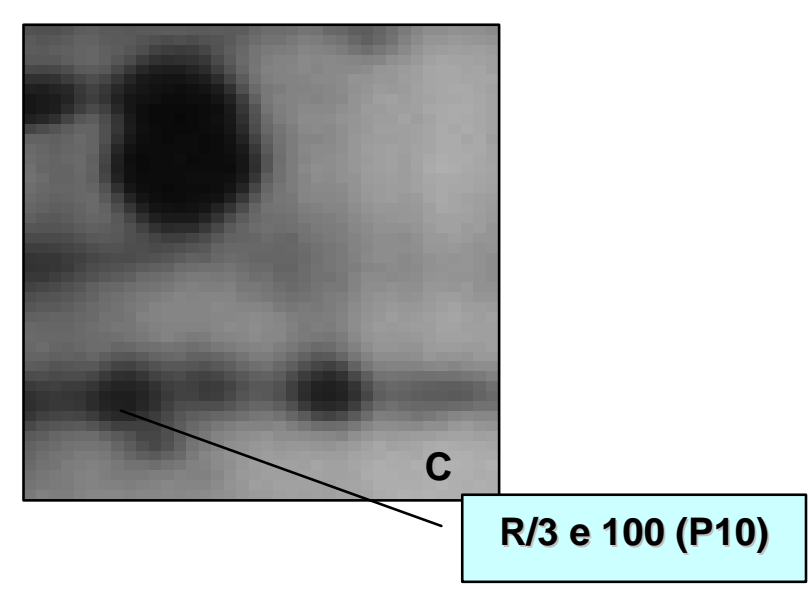

6,1

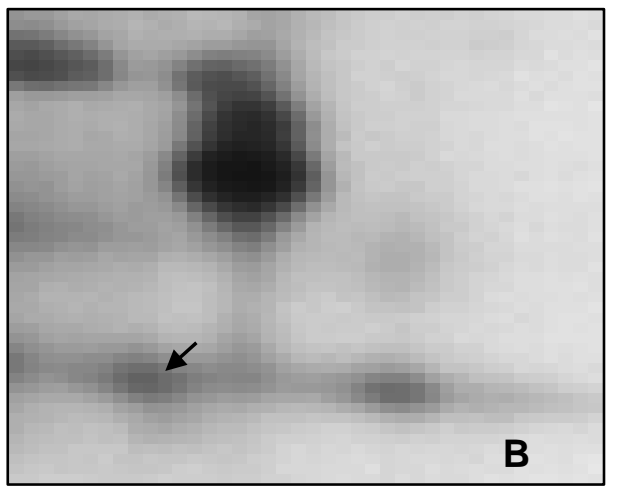

6.1

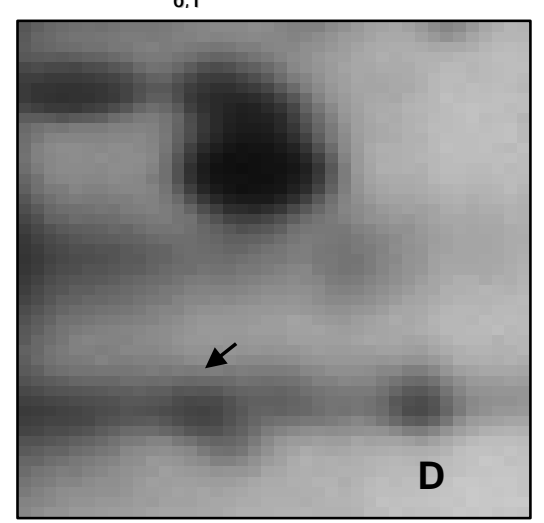

Figura 17 - Imagens detalhadas de proteínas de S. leopoliensis PCC7942 com expressão diferencial causada pela presença do $\mathrm{Cd}$, separadas em gel bidimensional ( $\mathrm{pH} 3-10$ ).

A e C: controles.

B: tratamento com $3 \mu \mathrm{M}$ de Cd por 1 hora.

D: tratamento com $100 \mu \mathrm{M}$ de $\mathrm{Cd}$ por 1 hora.

R/3 e 100: proteínas com expressão reprimida em 3 e $100 \mu \mathrm{M}$ de Cd. 


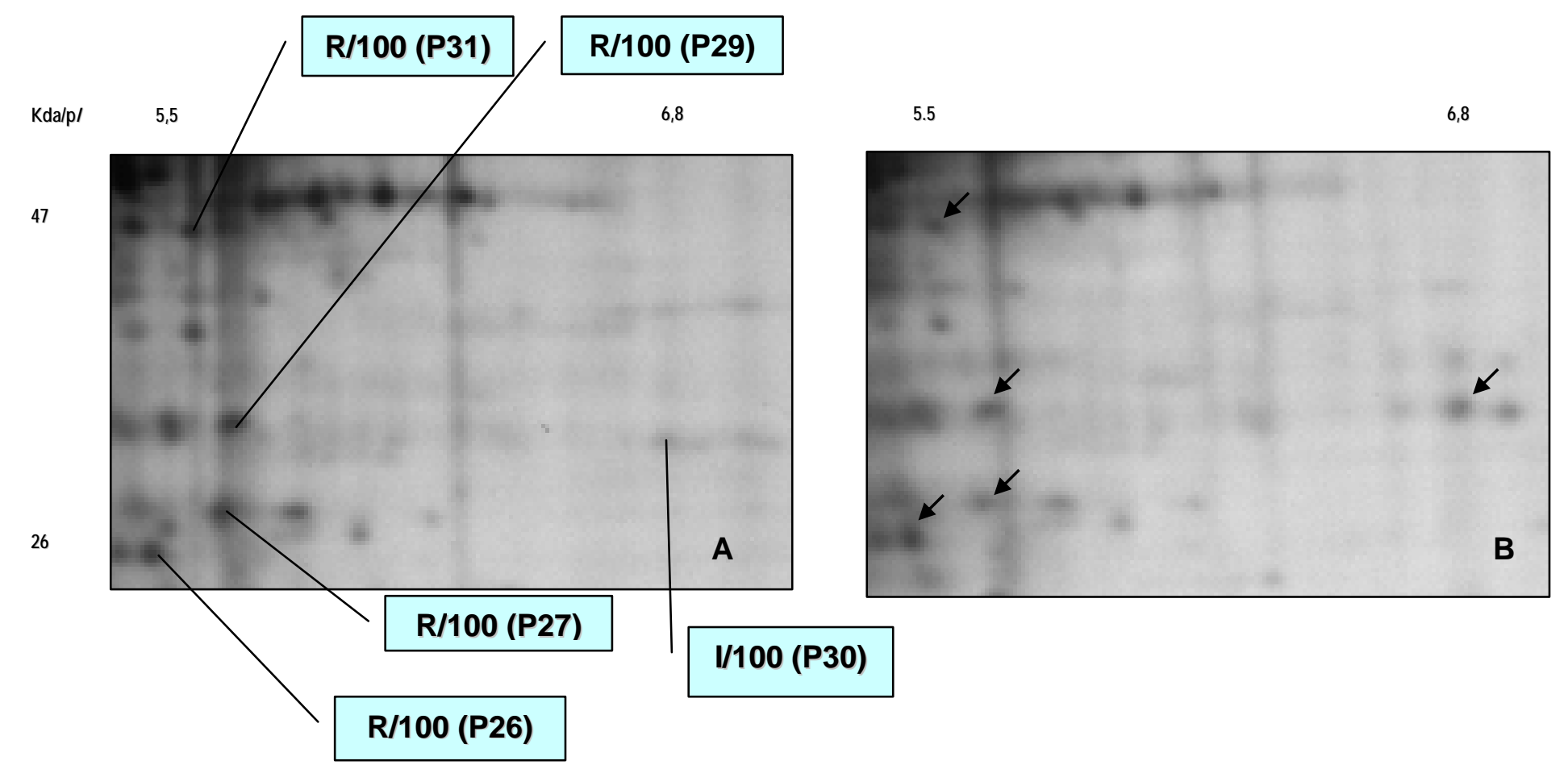

Figura 18 - Imagens detalhadas de proteínas de S. leopoliensis PCC7942 com expressão diferencial causada A: controle. pela presença de $\mathrm{Cd}$, separadas em gel bidimensional $(\mathrm{pH} 3-10)$.

B: tratamento com $100 \mu \mathrm{M}$ de Cd por 1 hora.

R/100: proteínas com expressão reprimida em $100 \mu \mathrm{M}$ de Cd.

1/100: proteínas com expressão induzida em $100 \mu \mathrm{M}$ de Cd. 
$\mathrm{kDa}$

I/3 e R/100 (P12)

6

$\mathrm{kDa}$

8,2

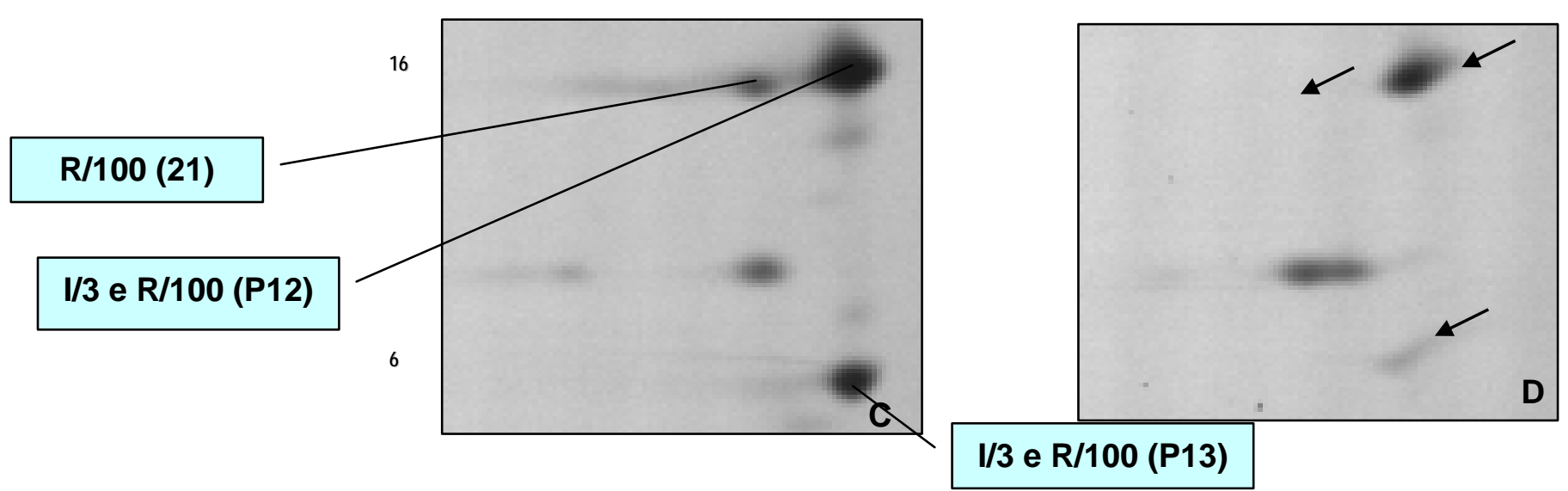

Figura 19 - Imagens detalhadas de proteínas de S. leopoliensis PCC 7942 com expressão diferencial causada pela presença de $\mathrm{Cd}$, separadas em gel bidimensional $(\mathrm{pH} 3-10)$.

A e C: controles.

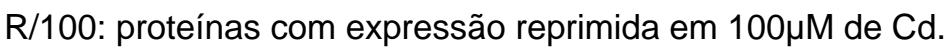

B: tratamento com $3 \mu \mathrm{M}$ de $\mathrm{Cd}$.

I/3 e R/100: proteínas com expressão induzida em $3 \mu \mathrm{M}$ e reprimida em $100 \mu \mathrm{M}$ de Cd.

D: tratamento com $100 \mu \mathrm{M}$ de Cd.
A

8,2

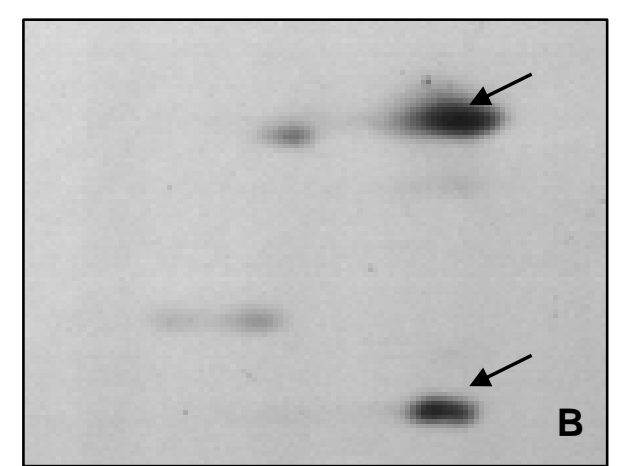

8,2 
Entre as proteínas com expressão diferencial, foram escolhidas as seis mais abundantes para identificação. Cinco delas foram analisadas com sucesso por MALDI-TOF-MS (P6, P11, P12, P13 e P14, Tabela 2), sendo quatro identificadas através da comparação com seqüências de proteínas depositadas no banco de dados do NCBI. Nas Figuras 20 a 24 estão apresentados os espectogramas dessas proteínas, obtidos nas análises com MALDI-TOF-MS. A metodologia de digestão das proteínas no gel mostrou-se eficiente. Foi possível detectar a proteína utilizada como controle positivo, o BSA, em 1, 0,5 e 0,1 $\mu \mathrm{g}$.

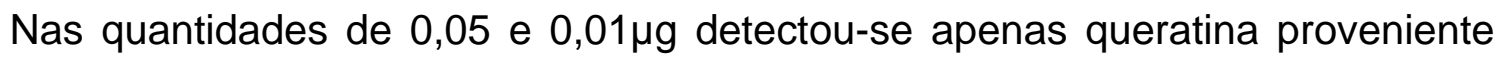
de contaminações durante o processamento das amostras. Os espectrogramas das cinco concentrações de BSA estão demonstrados nos Anexos A ao E. 
Tabela 2. Relação das proteínas expressas diferencialmente pela S. leopoliensis PCC7942 na presença de duas concentrações de Cd (3 e $100 \mu \mathrm{M})$ analisadas através de MALDI-TOF-MS, e identificadas por comparação com bancos de dados de proteínas usando o programa Mascot Wizard.

\begin{tabular}{|c|c|c|c|c|c|c|c|c|}
\hline Amostras & Provável proteína & $\begin{array}{l}\text { MMA } \\
\text { (kDa) }\end{array}$ & MMR (kDa) & $\mathrm{p} / \mathrm{A}$ & $\mathrm{p} / \mathrm{R}$ & Score & $\begin{array}{c}\text { Cobertura } \\
(\%)\end{array}$ & $n^{\circ}$ acesso \\
\hline P6 & Proteína hipotética & 27 & 7,28 & 4,4 & 8,71 & 40 & 76 & $\begin{array}{l}\text { gi|23127961 (Nostoc } \\
\text { punctiforme) }\end{array}$ \\
\hline P11 & $\begin{array}{l}\text { Ribulose- bisfosfato- } \\
\text { carboxilase/oxigenase }\end{array}$ & 10 & 13,10 & 5,89 & 5,58 & 121 & 60 & $\begin{array}{c}\text { gi|46129874 } \\
\text { (Synechococcus sp. } \\
\text { PCC7942) }\end{array}$ \\
\hline $\mathrm{P} 12$ & Isoleucil-tRNA sintetase & 16 & 15,67 & 8,2 & 9,25 & 64 & 60 & $\begin{array}{c}\text { gi|45512573 } \\
\text { (Synechococcus sp. } \\
\text { PCC7942) }\end{array}$ \\
\hline $\mathrm{P} 13$ & $\begin{array}{c}\text { Proteína de bactéria ligadora a } \\
\text { DNA }\end{array}$ & 6 & 9,73 & 8,23 & 9,1 & 54 & 58 & $\begin{array}{c}\text { gi|45513672 } \\
\text { (Synechococcus sp. } \\
\text { PCC7942) }\end{array}$ \\
\hline P14 & $\begin{array}{l}\text { Proteína da capa protéica do } \\
\text { carboxissoma }\end{array}$ & 7 & 10,9 & 5,13 & 5,87 & 75 & 49 & $\begin{array}{c}\text { gi|46129870 } \\
\text { (Synechococcus sp. } \\
\text { PCC7942) }\end{array}$ \\
\hline
\end{tabular}

MMA: massa molecular aparente.

MMR: massa molecular real.

$\mathrm{p} / \mathrm{A}$ : ponto isoelétrico aparente.

p/ R: ponto isoelétrico real. 


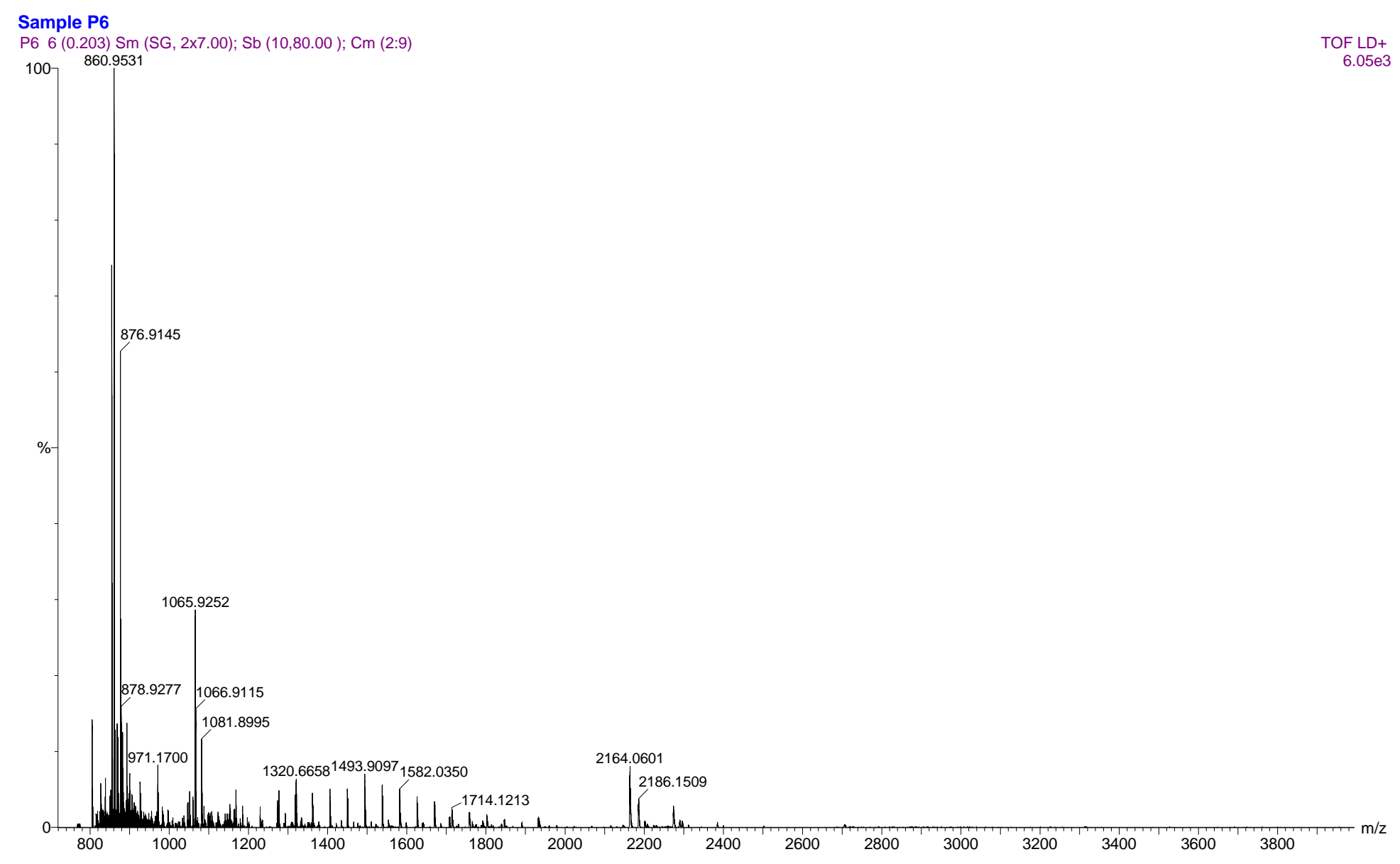

Figura 20 - Espectrograma da amostra P6 (Figura 15).

Nota: massas dos peptídeos originados da digestão da proteína com tripsina. Análise feita por MALDI-TOF-MS. 


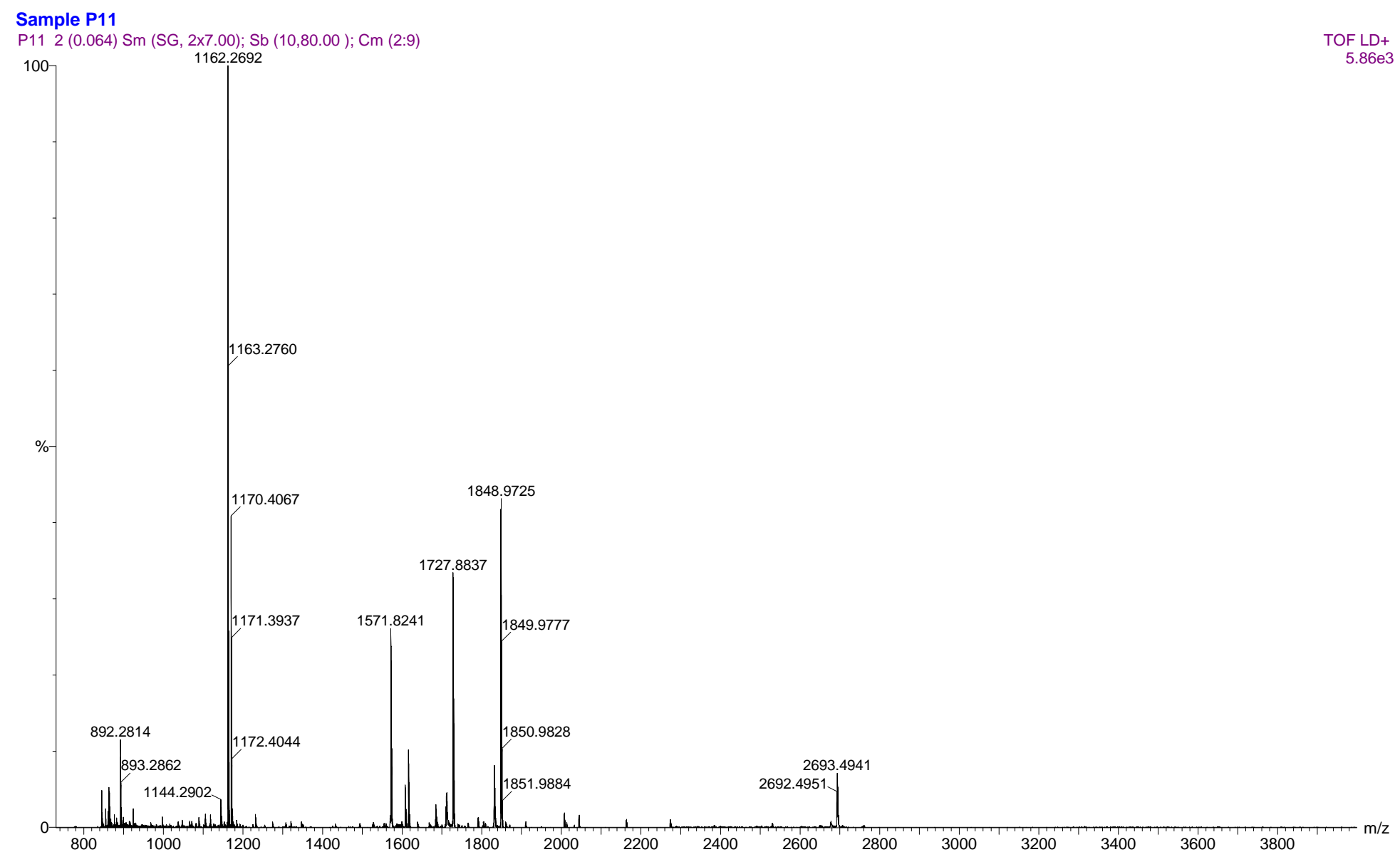

Figura 21 - Espectrograma da amostra P11 (Figura 14)

Nota: massas dos peptídeos originados da digestão da proteína com tripsina. Análise feita por MALDI-TOF-MS. 


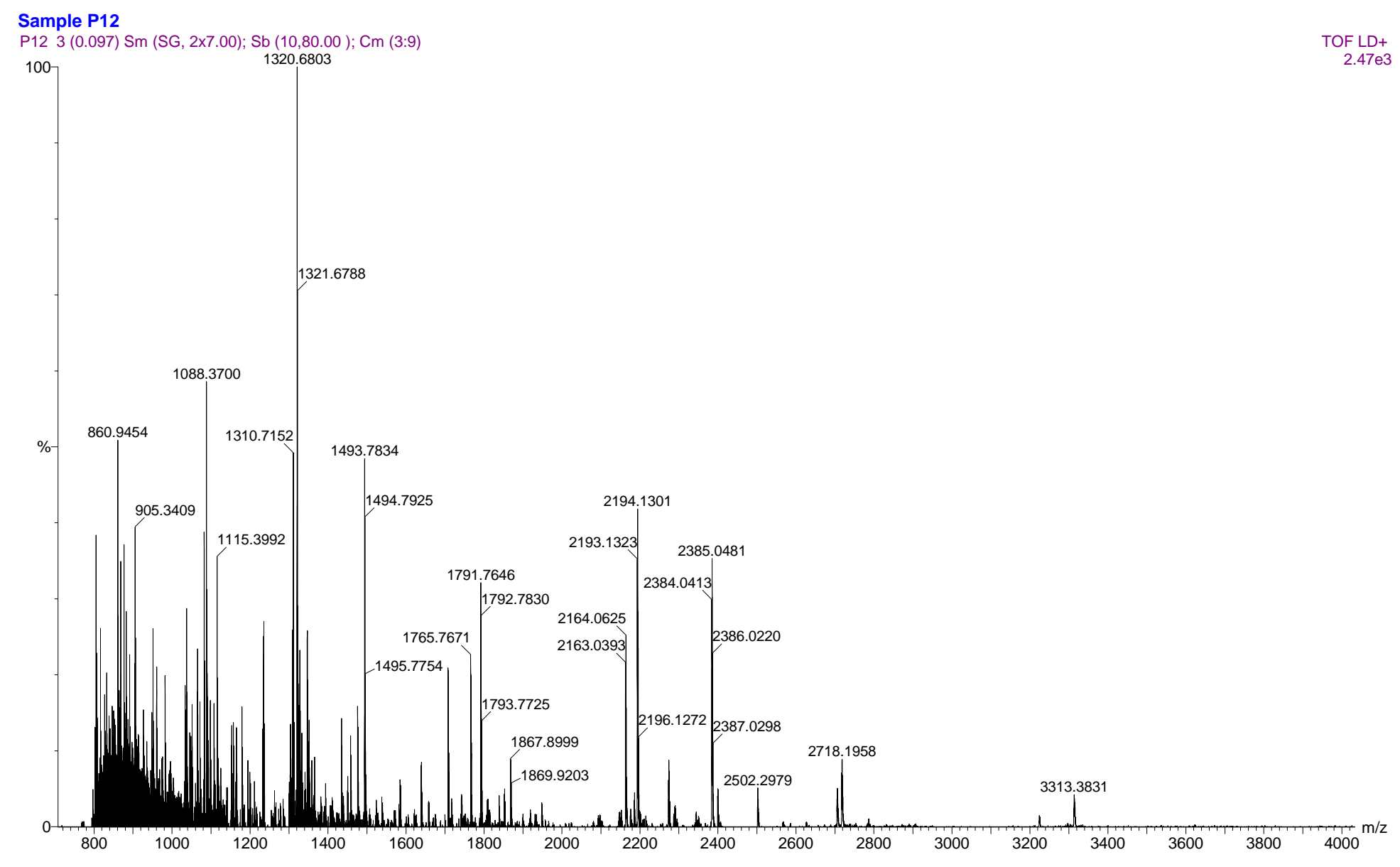

Figura 22 - Espectrograma da amostra P12 (Figura 19)

Nota: massas dos peptídeos originados da digestão da proteína com tripsina. Análise feita por MALDI-TOF-MS. 


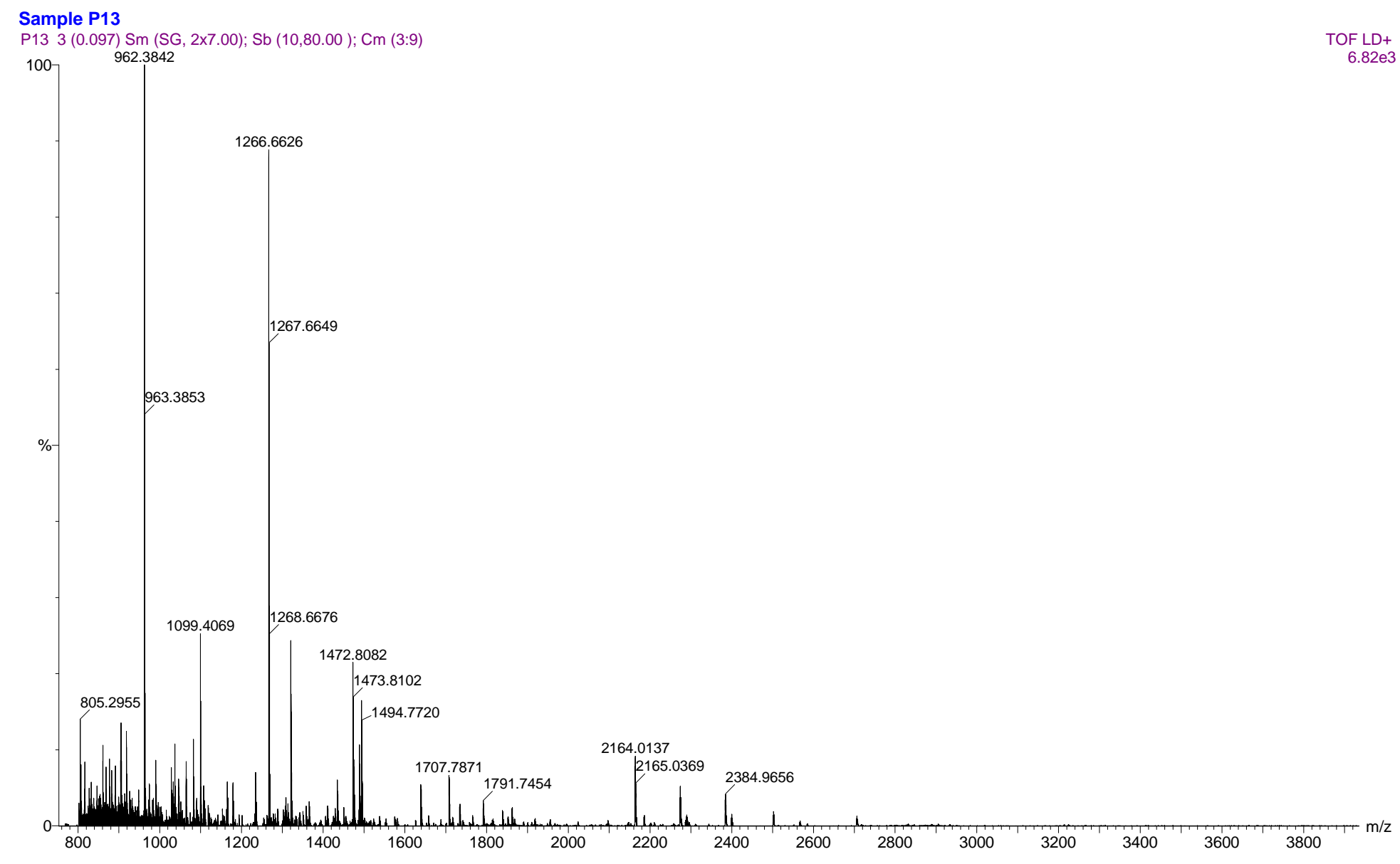

Figura 23 - Espectrograma da amostra P13 (Figura 19).

Nota: massas dos peptídeos originados da digestão da proteína com tripsina. Análise feita por MALDI-TOF-MS. 


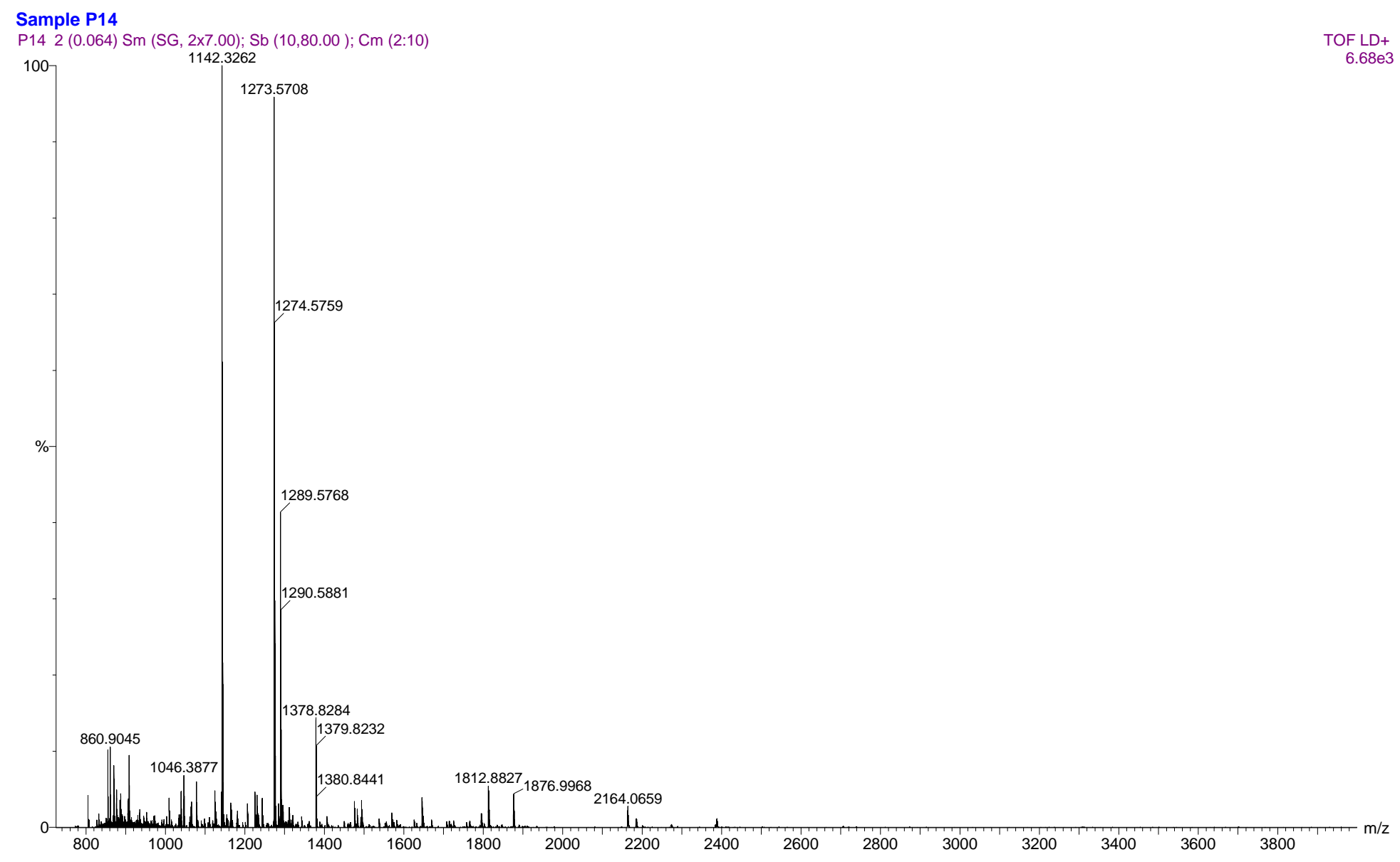

Figura 24 - Espectrograma da amostra P14 (Figura 14).

Nota: massas dos peptídeos originados da digestão da proteína com tripsina. Análise feita por MALDI-TOF-MS. 
Comparando-se as massas dos peptídeos originados da digestão tríptica das proteínas 11, 12, 13 e 14 com as massas dos peptídeos originados da digestão virtual das proteínas, consideradas aqui as mais prováveis, presentes nos bancos de dados, observa-se que a cobertura de peptídeos foi alta e a pontuação (score) foi baixa. Em outras palavras, o número de peptídeos originados das amostras cobriu uma grande parte das proteínas consideradas mais prováveis, entre 49 e 76 \% (Tabela 2). Porém, a pontuação foi baixa porque o número total de peptídeos originados das amostras apresentou maior homologia com outras proteínas de outros organismos listados no ranking de proteínas do que com a da Synechococcus sp. PCC7942. Isso aconteceu, provavelmente, devido a baixa massa molecular das proteínas aqui estudadas (entre 7 e $16 \mathrm{kDa}$ ) e pela pequena quantidade de peptídeos originados da digestão devido a baixa abundância dessas proteínas. As proteínas consideradas as mais prováveis, foram escolhidas a partir de vários caracteres: pl e massa molecular próximas ao das amostras, alta cobertura dos peptídeos e pertencentes a mesma espécie (Synechococcus sp. PCC7942). A proteína 6 não apresentou concordância dos caracteres acima listados com nenhuma proteína presente no banco de dados. Ela apresentou homologia com uma proteína hipotética da Nostoc punctiforme, com uma cobertura de 76\% (Tabela 2). Porém o pl e massa molecular de ambos não apresentaram semelhanças e a pontuação foi baixa. As hipóteses a serem consideradas para explicar esse fato é que esta proteína ainda não foi descrita em cianobactérias, ou ainda que a seqüência da proteína da $N$. punctiforme depositada no banco de dados não está completa.

A proteína 11, uma sub-unidade menor da ribulose bifosfato carboxilase/oxigenase (rubisco), foi reprimida na presença de $3 \mu \mathrm{M}$ de $\mathrm{Cd}$. Essa enzima está presente em cloroplastos de plantas e algas e em cianobactérias, e é uma componente chave da reação de fixação do $\mathrm{CO}_{2}$, onde este composto é incorporado na célula em uma forma orgânica (Nelson \& Cox, 2000). A função da sub-unidade menor não está bem descrita na literatura, 
porém, supõe-se que ela tem um papel regulatório, agindo em sítios catalíticos e de ativação da rubisco (Gibson \& Tabita, 1979; Incharoensakdi et al., 1986). Gibson \& Tabita (1979) propuseram que a sub-unidade menor da rubisco (1) promove a conformação da enzima, resultando na capacidade de metais, em conjunto com o $\mathrm{Mg}^{2+}$ e $\mathrm{Mn}^{2+}$, de dar suporte a ativação ou catálise da fixação de $\mathrm{CO}_{2}$; (2) aumenta a afinidade da enzima por $\mathrm{CO}_{2}$. Haiduch et al. (2001) estudando a expressão de proteínas em folhas de arroz submetidas ao estresse por metal, observaram a repressão das sub-unidades maiores e menores da rubisco na presença de cádmio, cobre e mercúrio. A coloração amarelada apresentada por essas folhas confirmou o fato desses metais estarem interferindo no sistema fotossintético. Em um outro trabalho, Pietrini et al. (2003), constataram que o cádmio inibiu a atividade e diminuiu a quantidade de rubisco em células da folha da gramínea Phragmites australis.

A proteína P14, uma componente da capa protéica do carboxissoma, foi induzida na presença de $100 \mu \mathrm{M}$ de Cd. Carboxissomas são inclusões citoplasmáticas poliédricas presentes em cianobactérias que participam do mecanismo de concentração de $\mathrm{CO}_{2}$. Para o funcionamento desse mecanismo basicamente dois componentes são necessários: (1) sistema de transporte que resulta no acúmulo de carbono inorgânico no interior da célula. Esse sistema de transporte tem preferência por $\mathrm{CO}_{2}$, mas também aceita a forma $\mathrm{HCO}_{3}{ }^{-}$. (2) o carboxissoma, que é composto de uma capa protéica formada por cerca de 815 polipeptídeos, e abriga, no seu interior, a enzima rubisco. A capa protéica desse corpúsculo permite a entrada de $\mathrm{HCO}_{3}{ }^{-}$e no seu interior a enzima anidrase carbônica ( $\mathrm{CA}$ ) converte esta forma em $\mathrm{CO}_{2}$. Essa capa também impede a saída do $\mathrm{CO}_{2}$, mantendo altos níveis interno deste composto, possibilitando a rubisco desempenhar a sua atividade. Algumas cianobactérias apresentam um grande número de carboxissomas quando submetidas à condição de limitação de carbono inorgânico (Orús et al., 2001). Culturas de Synechococcus PCC630 crescidas em um meio com escassez de $\mathrm{CO}_{2}$ apresentaram um número muito maior de carboxissomas do que as culturas 
crescidas com aporte de $\mathrm{CO}_{2}$ (McKay et al., 1993). Outro fator que propicia o aumento no número de carboxissomas em cianobactérias é a deficiência de $\mathrm{Na}^{+}$(Avendaño et al., 1989).

As duas proteínas discutidas acima, as quais estão relacionadas com atividade fotossintetizante, foram afetadas pelo cádmio. O cádmio na concentração tolerável $(3 \mu \mathrm{M})$ reprimiu a enzima rubisco em 1,5 vezes, enquanto que não se observou a mesma resposta com a concentração letal do metal $(100 \mu \mathrm{M})$. A observação de expressão diferencial da rubisco apenas na concentração menor do metal pode ter explicações dentro do quadro fisiológico da célula, ou a diferença de expressão foi pequena e não detectada nas análises dos géis. Observou-se, também, uma alta indução (2,3 vezes) da proteína da capa protéica do carboxissoma apenas no estresse gerado por 100 $\mu \mathrm{M}$ do metal. Na gramínea Phragmites australis também foram observadas respostas metabólicas diferenciais quando essa planta foi submetida a diferentes concentrações de cádmio (50 e $100 \mu \mathrm{M}$ ) (Pietrini et al., 2003). Nessa gramínea o conteúdo de $\mathrm{Fe}$, $\mathrm{Ca}$ e $\mathrm{Zn}$ aumentaram significativamente no tratamento com $50 \mu \mathrm{M}$ de $\mathrm{Cd}$ em comparação com o controle (sem metal). Entretanto, no tratamento com $100 \mu \mathrm{M}$ de Cd os níveis de Fe e Zn não mudaram e o nível de Ca diminuiu em relação ao controle. Observou-se, também, que a concentração de $100 \mu \mathrm{M}$ diminuiu mais a atividade e quantidade da rubisco, assim como a atividade fotossintética, do que a concentração de 50 $\mu \mathrm{M}$ de $\mathrm{Cd}$.

Informações complementares aos dados obtidos com este estudo de expressão de proteínas que poderiam auxiliar no esclarecimento de como essas duas doses de Cd estão interferindo no sistema fotossintetizante das células, possivelmente poderiam ser alcançados com a medição da atividade fotossintética e a análise da ultra-estrutura dos carboxissomas das culturas de Synechococcus leopoliensis PCC7942 expostas a essas doses do metal.

A proteína P13, chamada Dpsa, é uma proteína que se liga ao DNA. Ela foi induzida em $3 \mu \mathrm{M}$ e reprimida em $100 \mu \mathrm{M}$ de cádmio. Essa proteína 
pertence à família Dps, um grupo de proteínas de bactérias expressas em situações de estresse e que se liga ao DNA conferindo resistência aos danos causados pelos peróxidos durante o período de estresse oxidativo ou de limitação de nutrientes por um tempo longo. A expressão desta proteína em situação de estresse foi bem caracterizada em E. coli, Bacillus subtilis e Synechococcus sp., onde foi observado a atividade de ligação ao DNA e acúmulo da proteína na célula (Almiron et al., 1992; Peña et al., 1995; Chen, et al.,1993, citados por Peña \& Bullerjahn, 1995). Sen et al. (2000) sugeriu que essa proteína também tem a função de capturar e acumular ferro na célula de Synechococcus sp. PCC7942 em situações de escassez deste nutriente. Foi também sugerido que esta proteína participa da captura de íons de Fe em E. coli como mecanismo de proteção do DNA contra danos oxidativos (Grant et al., 1998). A expressão dessa proteína sugere que a exposição das células ao cádmio durante uma hora causou estresse oxidativo, porém apenas na presença da concentração tolerável foi ativado esse sistema de proteção ao DNA, enquanto que na concentração letal a proteína foi reprimida.

A proteína $\mathrm{P} 12$, uma isoleucil-tRNA sintetase também foi induzida em 3 $\mu \mathrm{M}$ e reprimida em $100 \mu \mathrm{M}$ de $\mathrm{Cd}$. Essa proteína pertence à família da aminoacil-tRNA sintetase, as quais são responsáveis pela acilação entre os RNAs transportadores e seus respectivos aminoácidos. Algumas dessas sintetases possuem sítios de ligação a metais semelhantes aos motivos estruturais "zinc finger" (Berg et al., 1986; Miller, et al., 1991 citados por Xu et al., 1994). Provavelmente, o aumento da produção na quantidade de isoleuciltRNA reflete a produção de proteínas com isoleucina em sua constituição. He et al. (2002) investigando as proteínas queladoras de Cd extraídas de sementes de arroz e trigo expostas ao metal, usando método cromatográfico, encontraram grandes quantidades de isoleucina, ácido glutâmico, cisteína, valina, leucina e tirosina nas proteínas extraídas.

Neste estudo observou-se que as proteínas 12 e 13 não apresentaram o mesmo padrão de expressão nos tratamentos controles dos dois 
experimentos independentes (Figura 19). Essa diferença na expressão, provavelmente, foi causada pela ação de algum fator ambiental. Como os experimentos foram desenvolvidos na mesma câmara de crescimento onde as condições de temperatura e intensidade luminosa são controladas, supõe-se que o fator interferente pode ter sido diferenças na disponibilidade de nutrientes. Sabe-se, também, que a proteína 13 (provável produto do gene Dpsa) é expressa em situações de limitação de nutrientes conforme já discutido acima. Neste estudo, a comparação entre os proteomas de células de $S$. leopoliensis PCC7942 expostas e não expostas ao Cd foi feita com culturas desta cianobactéria no final da fase logarítmica, uma vez que se observou nos ensaios de tolerância ao $\mathrm{Cd}$, que esta era a fase onde as células eram mais tolerantes ao metal. Porém, nessa fase pode ter ocorrido falta de nutrientes para as células, o que pode ter influenciado a expressão de proteínas. Estudos com culturas no meio da fase logarítmica talvez possam trazer informações complementares e esclarecedoras sobre a expressão desses dois genes e de outros expressos diferencialmente.

Atualmente, o genoma da Synechococcus sp. PCC7942 está sendo seqüenciado, e certamente, quando a seqüência das bases for conhecida e as proteínas anotadas, será possível uma identificação mais apurada das proteínas aqui estudadas. 


\section{CONCLUSÕES}

- A concentração máxima de cádmio tolerável pela cianobactéria Synechococcus leopoliensis PCC 7942 foi de $3 \mu \mathrm{M}$;

- As culturas de cianobactéria crescidas na presença de $3 \mu \mathrm{M}$ apresentaram uma fase de adaptação de 4 dias, dois dias a mais das culturas controles;

- O tempo de geração calculado foi de 1,6 e 3,0 dias para as culturas controles e com $3 \mu \mathrm{M}$ de Cd, respectivamente;

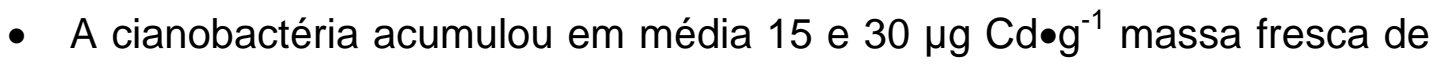
célula quando submetida, por uma hora, a $3 \mu \mathrm{M}$ e $100 \mu \mathrm{M}$ de $\mathrm{Cd}$, respectivamente;

- A concentração da forma considerada a mais tóxica $\left(\mathrm{Cd}^{2+}\right)$ nas culturas no meio BG-11 foi calculada em 0,08 $\mu \mathrm{M}, 0,69 \mu \mathrm{M}, 2,15 \mu \mathrm{M}$ e $75 \mu \mathrm{M}$ para as doses de 1, 3, 5 e $100 \mu \mathrm{M}$ de $\mathrm{CdCl}_{2}$, respectivamente;

- A maioria das proteínas expressa pela Synechococcus leopoliensis PCC7942 apresentou ponto isoelétrico ácido e várias isoformas;

- No tratamento com $3 \mu \mathrm{M}$ de $\mathrm{Cd}$, duas proteínas foram induzidas e 11 foram reprimidas. No tratamento com $100 \mu \mathrm{M}$ de $\mathrm{Cd}$, duas proteínas foram induzidas e 20 reprimidas;

- Dentre as proteínas que foram diferencialmente expressas em ambos tratamentos, estão duas que foram reprimidas nos dois tratamentos e duas que foram induzidas em $3 \mu \mathrm{M}$ de $\mathrm{Cd}$ e reprimidas em $100 \mu \mathrm{M}$ do metal. 
- Quatro proteínas foram identificadas: Uma sub-unidade menor da ribulose bifosfato carboxilase/oxigenase (rubisco); uma proteína da capa do carboxissoma; a Dpsa, uma proteína que se liga ao DNA; e uma isoleucil-tRNA sintetase.

- A enzima rubisco foi reprimida na presença de $3 \mu \mathrm{M}$ de $\mathrm{Cd}$ e a proteína da capa do carboxissoma foi induzida em $100 \mu \mathrm{M}$ de Cd. Tanto a rubisco quanto a proteína da capa do carboxissoma estão envolvidas na atividade fotossintética das células.

- A Dpsa e a isoleucil-tRNA sintetase foram induzidas na presença de 3 $\mu \mathrm{M}$ de $\mathrm{Cd}$ e reprimidas em $100 \mu \mathrm{M}$ de Cd. A Dpsa é expressa em situações de estresse oxidativo e a isoleucil-tRNA sintetase está relacionada com a síntese de proteínas contendo isoleucina. 
ANEXOS 


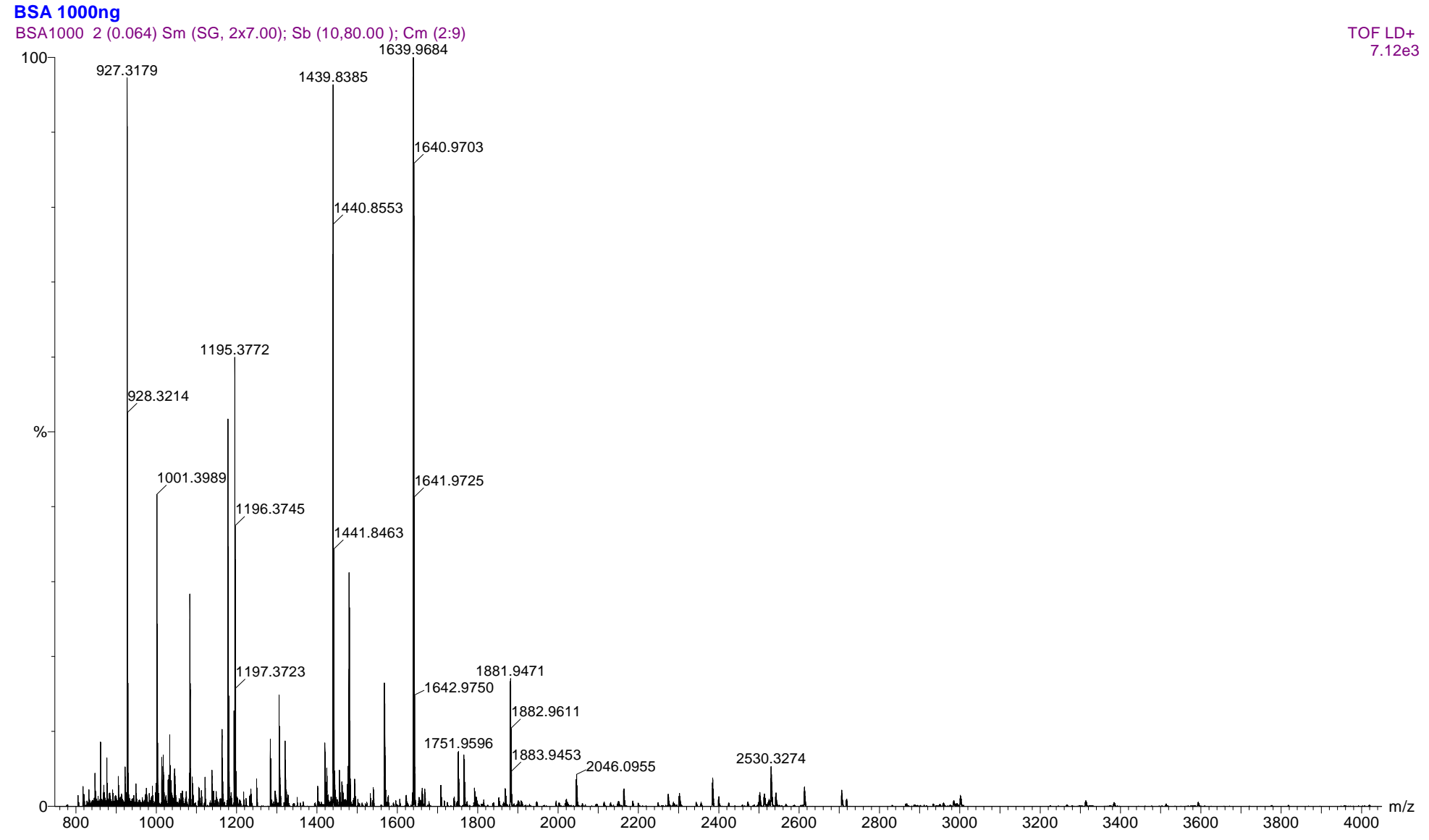

ANEXO A - Espectrograma de BSA $1 \mu \mathrm{g}$.

Nota: massas dos peptídeos originados da digestão da proteína com tripsina. Análise feita por MALDI-TOF-MS. 


\section{BSA 500ng}

BSA500 3 (0.102) Sm (SG, 2x7.00); Sb (10,80.00); Cm (3:9)

$100 \quad 927.3381$

TOF LD+

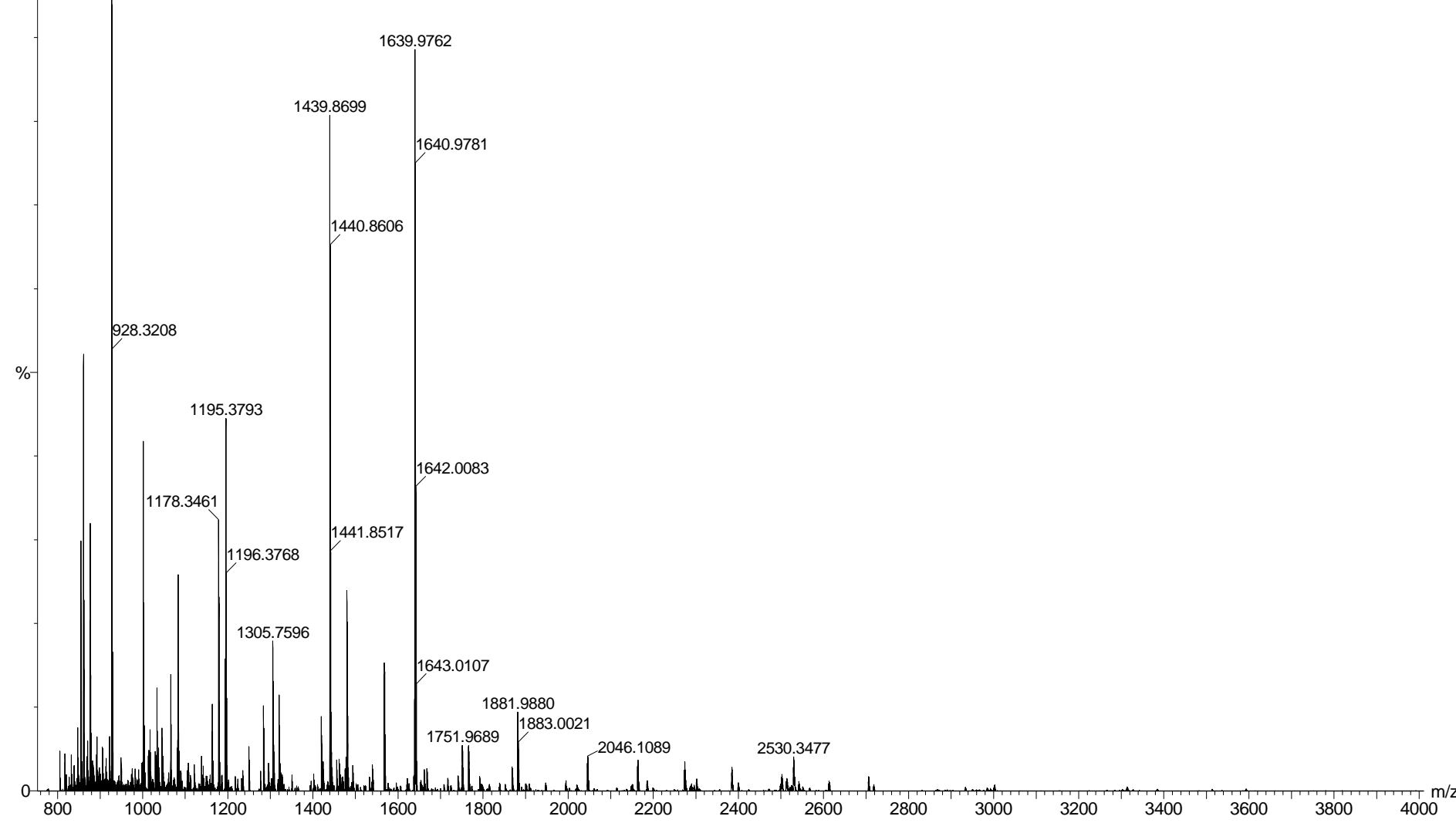

ANEXO B - Espectrograma de BSA 0,5 $\mu \mathrm{g}$

Nota: massas dos peptídeos originados da digestão da proteína com tripsina. Análise feita por MALDI-TOF-MS. 


\section{BSA 100ng}

BSA100 5 (0.168) Sm (SG, 2x7.00); Sb (10,80.00); Cm (4:8)

$100 \quad 860.9473$

${ }^{100}{ }^{860.9473}$

927.3427

1320.6464

1037.3632

$21.6449 \quad 1639.9017$

1083.3896

1439.8126

1440.82931640 .9036

1638.8446

1179.3712

||$|\quad| \begin{array}{lll}1767.7391 & 2164.0298 & 2502.2549\end{array}$

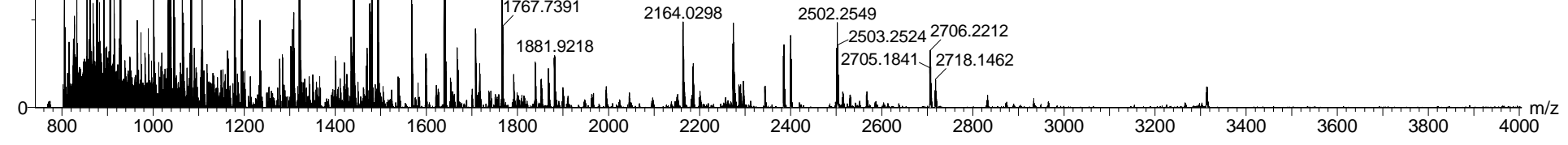

ANEXO C - Espectrograma de BSA 0,1 $\mu \mathrm{g}$.

Nota: massas dos peptídeos originados da digestão da proteína com tripsina. Análise feita por MALDI-TOF-MS. 


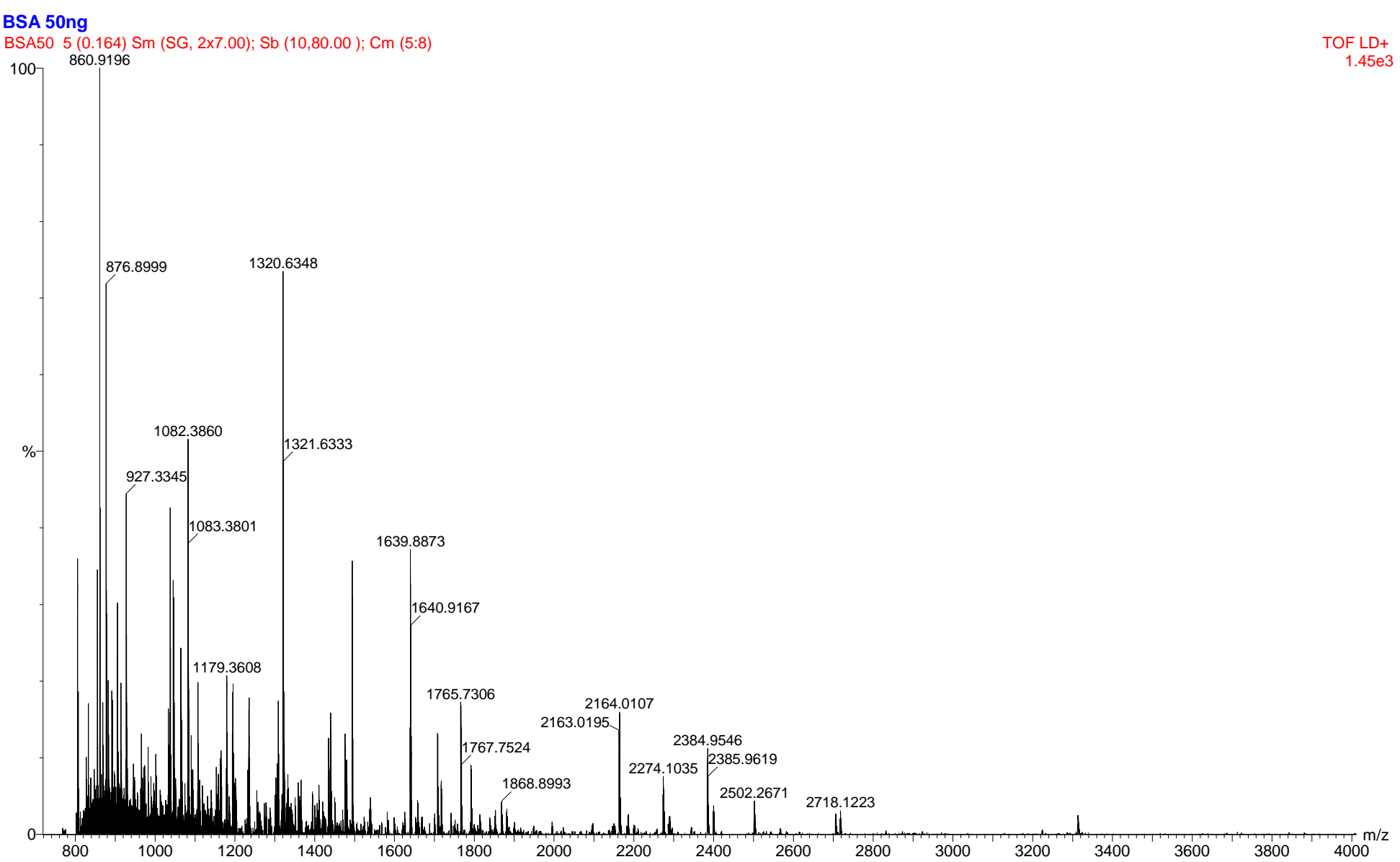

ANEXO D - Espectrograma de BSA 0,05 $\mu \mathrm{g}$

Nota: massas dos peptídeos originados da digestão da proteína com tripsina. Análise feita por MALDI-TOF-MS. 


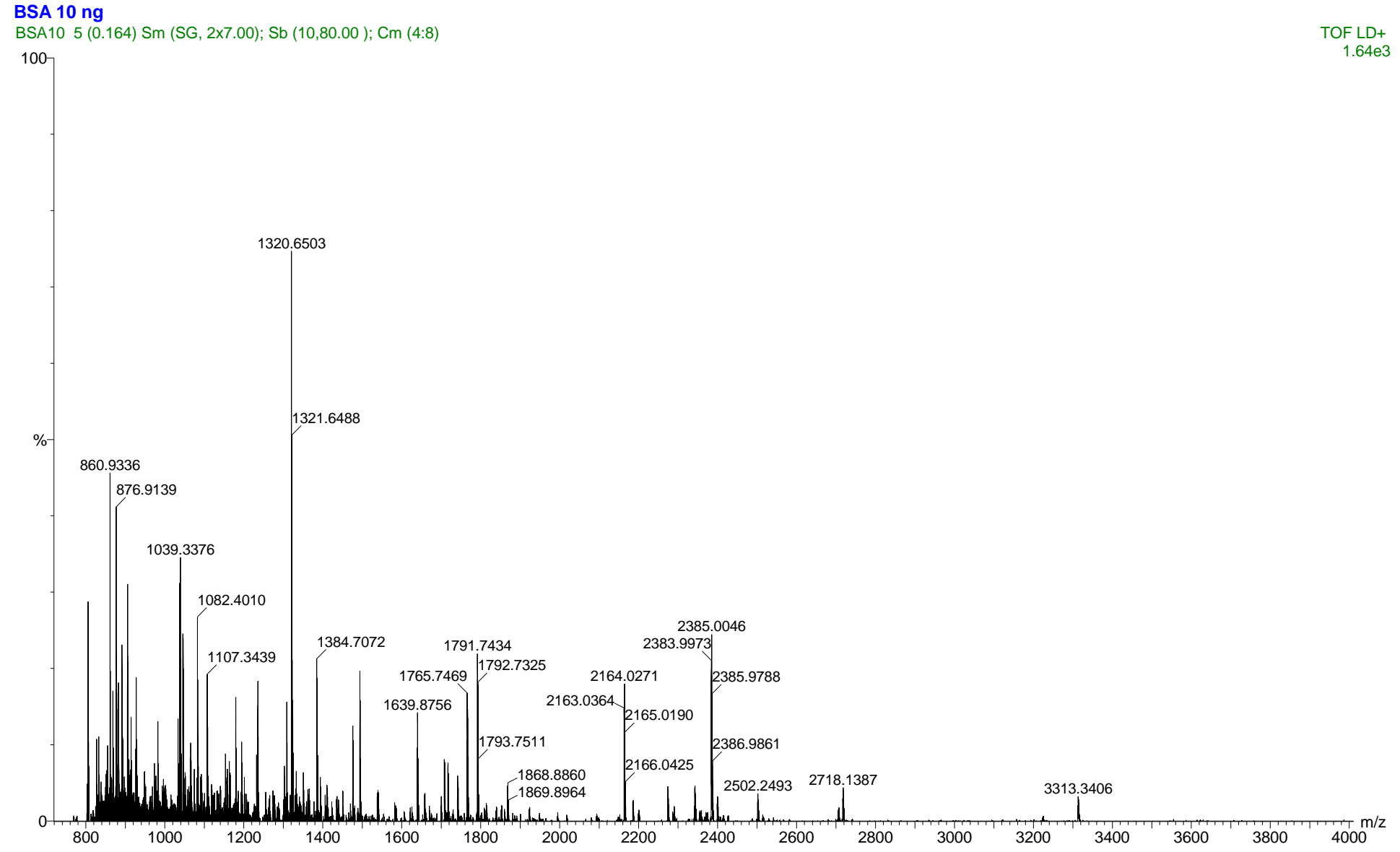

ANEXO E - Espectrograma de BSA 0,01 $\mu \mathrm{g}$

Nota: massas dos peptídeos originados da digestão da proteína com tripsina. Análise feita por MALDI-TOF-MS. 


\section{REFERÊNCIAS BIBLIOGRÁFICAS}

ALLISON, J.D.; BROWN, D.S.; NOVO-GRADAC, K.J. MINTEQA2/PRODEFA2:

a geochemical assessment model for environmental systems (software). Athens: USEPA, Environmental Research Laboratory, 1990.

ALLEN, M.B. Simple conditions for growth of unicellular blue-green algae on plates. Journal of Phycology, v.4, n.1, p.1-4, 1968.

AVENDANO, M.C.; MAESO, E.S.; NIEVA, M.; VALIENTE, E.F. Effect of sodium deficiency on the ultrastructure of the cyanobacterium Anabaena PCC7119. Journal of Plant Physiology, v.135, n.4, p.409-415, 1989.

BAKER, J.A.; NEILAN, B.A.; ENTSCH, B.; MCKAY, D.B. Identification of cyanobacteria and their toxigenicity in environmental samples by rapid molecular analysis. Environmental Toxicology, v.16, n.6, p.472-482, 2001.

BAULD, J. Occurrence of benthic microbial mats in saline lakes. Hydrobiologia, v.81, n.2, p.87-111, 1981. 
BEVERIDGE, T.J.; HUGHES, M.N.; LEE, H.; LEUNG, K.T.; POOLE, R.K.; SAVVAIDIS, I.; SILVER, S.; TREVORS, J.T. Metal-microbe interactions: contemporary approaches. Advances in Microbial Physiology, v.38, p.177-243, 1997.

BLINDAUER, C.A.; HARRISON, M.D.; PARKINSON, J.A.; ROBINSON, A.K.; CAVET, J.S.; ROBINSON, N.J.; SADLER, P.J. A metallothionein containing a zinc finger within a four-metal cluster protects a bacterium from zinc toxicity. Proceedings of National Academy of Science of the USA, v.98, n.17, p.9593-9598, 2001.

BLOCK, M.A.; GROSSMAN, A.R. Identification and purification of a derepressible alkaline-phosphatase from Anacystis-nidulans R2. Plant Physiology, v.86, n.4, p.1179-1184, 1988.

BLUM, H.; BEIER, H.; GROSS, H. Improved silver staining of plants proteins, RNA and DNA in polyacrylamide gels. Electrophoresis, v.8, p.93-99, 1987.

BOLAÑOS, L.; GONZALEZ, M.G.; MATEO, P.; BONILLA, I. Differential toxicological response to cadmium in Anabena strais PCC 7119 grown with NO-3 NH+4 as nitrogen source. Journal of Plant Physiology, v.140, n.3, p.345-349, 1992.

BONTIDEAN, I.; LOYD, J.R.; HOBMAN, J.L.; WILSON, J.R.; CSÖREGI, E.; MATTIASSON, B.; BROWN, N.L. Bacterial metal resistance proteins and their use in biosensors for the detection of bioavailable heavy metals. Journal of Inorganic Biochemistry, v.79, n.1-4, p.225-229, 2000. 
BRADFORD, M.M. A rapid and sensitive method for the quantification of microgram quantities of protein utilizing the principle of protein-dye binding. Analytical Biochemistry, v.72, p.248-254, 1976.

BUSTOS, S.A.; SCHAEFER, M.R.; GOLDEN, S.S. Different and rapid responses of four cyanobacterial psbA transcripts to changes in light intensity. Journal of Bacteriology, v.172, n.4, p.1998-2004, 1990.

CASTENHOLZ, R.W.; WATERBURY, J.B. Cyanobacteria. In: STALEY, J.T.; BRYANT, M.P.; PFENNING, N.; HOLT, J.G. Bergey's manual of systematic bacteriology. Baltimore: Williams and Wilkins, 1989. v.3, p.1710-1727.

CASTENHOLZ, R.W.; GARCIA-PICHEL, F. Cyanobacterial responses to UV radiation. In: WHITTON, B.A.; POTTS, M. The ecology of cyanobacteria: their diversity in time an space. Dordrecht: Kluwer Academic Publishers, 2000. cap.21, p.591-611.

COLLIER, J.L.; GROSSMAN, A.R. A small polypeptide triggers complete degradation of light-harvesting phycobiliproteins in nutrient-deprived cyanobacteria. EMBO Journal, v.13, n.5, p.1039-1047, 1994.

ERBE, J.L.; TAYLOR, K.B.; HALL, L.M. Metalloregulation of the cyanobacteria smt locus: identification of the smtB-bindings sites and direct interaction with metals. Nucleic Acid Research, v.23, n.12, p.2472-2478, 1995.

FERIANC, P.; FAREWELL, A.; NYSTROM, T. The cadmium-stress stimulon of Escherichia coli K-12. Microbiology, v.144, n.4, p.1045-1050, 1998. 
FERNANDEZ-PIÑAS, F.; MATEO, P.; BONILLA, I. Binding of cadmium by cyanobacterial growth media: free ion concentration as a toxicity index to the cyanobacterium Nostoc UAM 208. Archives of Environmental Contamination and Toxicology, v.21, n.3, p.425-431, 1991.

FIORE, M.F.; TREVORS, J.T. Cell composition and metal tolerance in cyanobacteria. Biometals, v.7, p.83-103, 1994.

FIORE, M.F.; MOON, D.H.; TREVORS, J.T. Metal resistance and accumulation in cyanobacteria. In: WONG, Y.S.; TAM, N.F.Y. Wastewater treatment with algae. Berlin: Springer-Verlag, 1998. p.111-124.

FOSTER, P.; MOREL, F.M.M. Reversal of cadmium toxicity in a diatom: an interaction between cadmium activity and iron. Limnology and Oceanography, v.27, n.4, p.745-752, 1982.

FULDA, S.; HUANG, F.; NILSSON, F.; HAGEMANN, M.; NORLING, B. Proteomics of Synechocystis sp strain PCC 6803: identification of periplasmic proteins in cells grown at low and high salt concentrations. European Journal of Biochemistry, v.267, n.19, p.5900-5907, 2000.

GARDEA-TORRESDEY, J.L.; ARENAS, J.L.; FRANCISCO, N.M.C.; TIEMAN, K.J.; WEBB, R. Ability of immobilized cyanobacteria to remove metal ions from solution and demonstration of the presence of metallothionein genes in various strains. Journal of Hazardous Substance Research, v.1, p.118, 1998.

GIBSON, J.L.; TABITA, F.R. Activation of ribulose 1,5-bisphosphate carboxylase from Rhodopseudomonas sphaeroides: probable role of the small subunit. Journal of Bacteriology, v.140, n.3, p.1023-1027, 1979. 
GOLDEN, S.S.; NALTY, M.S.; CHO, C.D.S. Genetic-relationship of 2 highly studied Synechococcus strains designated Anacystis-nidulans. Journal of Bacteriology, v.171, n.1, p.24-29, 1989.

GORBUNOV, M.Y.; GORBUNOVA, E.A. The effect of cadmium ions on photosynthesis and the delayed fluorescence of chlorophyll in cyanobacterium Anabaena variabilis Kütz. Russian Journal of Plant Physiology, v.40, n.5, p.760-763, 1993.

GÖRL, M.; SAUER, J.; BAIER, T.; FORCHHAMMER, K. Nitrogen-starvation induced chlorosis in Synechococcus PCC 7942: adaptation to long-term survival. Microbiology, v.144, p.2449-2458, 1998.

GRIGORIEVA, G.; SHESTAKOV, S. Transformation in cyanobacterium Synechocystis sp. 6803. FEMS Microbiology Letters, v.13, p.367-370, 1982.

GROSSMAN, A.R.; SCHAEFER, M.R.; CHIANG, G.G.; COLLIER, J. The responses of cyanobacteria to environmental conditions: light and nutrients. In: BRYANT, D.A. The molecular biology of cyanobacteria. Dordrecht: Kluwer Academic Publishers, 1994. cap.21, p.641-675.

HAJDUCH, M.; RANDEEP, R.; AGRAWAL, G.K.; YONEKURA, M.; PRETOVA, A. High-resolution two-dimensional electrophoresis separation of proteins from metal-stressed rice (Oryza sativa L.) leaves: drastic reductions/ fragmentation of ribulose-1,5-bisphosphate carboxylase/oxygenase and induction of stress-related proteins. Electrophoresis, v.22, n.13, p.28242831, 2001. 
HE, M.C.; WONG, J.W.C.; YANG, J.R. The patterns of Cd-binding proteins in rice and wheat seed and their stability. Journal of Environmental Science and Health. Part A: Toxic/Hazardous Substances \& Environmental Engineering, v.37, n.4, p.541-551, 2002.

HERRANEN, M.; BATTCHIKOVA, N.; ZHANG, P.; GRAF, A.; SIRPIO, S.; PAAKKARINEN, V.; ARO, E. Towards functional proteomics of membrane protein complexes in Synechocystis sp. PCC 6803. Plant Physiology, v.134, n.1, p.470-481, 2004.

HONDA, D.; YOKOTA, A.; SUGIYAMA, J. Detection of seven major evolutionary lineages in cyanobacteria based on the 16S rRNA gene sequence analysis with new sequences of five marine Synechococcus strains. Journal of Molecular Evolution, v.48, n.6, p.723-739, 1999.

HOUMARD, J.; DE MARSAC, N.T. Cyanobacterial genetics tools: current status. In: PACKER, L.; GLAZER, A.L. Methods in enzymology. San Diego: Academic Press, 1988. v.167, cap.89, p.808-850.

HUANG, F.; PARMRYD, I.; NILSSON, F.; PERSSON, A.L.; PAKRASI, H.B.; ANDERSSON, B.; NORLING, B. Proteomics of Synechocystis sp. Strain pcc 6803: identification of plasma membrane proteins. Molecular \& Cellular Proteomics, v.1, n.12, p.956-966, 2002.

HUCKLE, J.M.; MORBY, A.P.; TURNER, J.S.; ROBINSON, N.J. Isolation of the smt A gene encoding a prokaryotic metallothionein. Molecular Microbiology, v.7, p.177-187, 1993. 
HUSAINI, Y.; SINGH, A.K.; RAI, L.C. Cadmium toxicity to photosynthesis and associated electron transport system of Nostoc linckia. Bulletin of Environmental Contamination and Toxicology, v.46, n.1, p.146-150, 1991.

IMHOFF, J.F. Taxonomy, phylogeny, and general ecology of anoxygenic phototrophic bacteria. In: MANN, N.H.; CARR, N.G. Photosynthetic prokaryotes. New York: Plenum Press, 1992. cap.2, p.53-67.

INBAR, O.; RON, E.Z. Induction of cadmium tolerance in Escherichia-coli k-12. FEMS Microbiology Letters, v.113, n.2, p.197-200, 1993.

INCHAROENSAKDI, A.; TAKABE, T.; AKAZAWA, T. Role of the small subunit of ribulose-1,5-bisphosphate carboxylase/oxygenase in the activation process. Archives of Biochemistry and Biophysics, v.248, n.1, p.62-70, 1986.

IWAI, M.; KATOH, H.; KATAYAMA, M.; IKEUCHI, M. Improved genetic transformation of the thermophilic cyanobacterium, Thermosynechococcus elongatus BP-1. Plant and Cell Physiology, v.45, n.2, p.171-175, 2004.

KANEKO, T.; TANAKA, A.; SATO, S. et al. Sequence analysis of the genome of the unicellular cyanobacterium Synechocystis sp. strain PCC 6803. I. Sequence features in the $1 \mathrm{Mb}$ region from Map Positions $64 \%$ to $92 \%$ of the Genome. DNA Research, v.2, n.4, p.153-166, 1995.

KOTANI, H.; TABATA, S. Lessons from sequencing of the genome of a unicellular cyanobacterium, Synechocystis sp. PCC6803. Annual Review of Plant Physiology and Plant Molecular Biology, v.49, p.151-171, 1998. 
LAUBE, V.M.; MCKENZIE, C.N.; KUSHNER, D.J. Strategies of response to copper, cadmium, and lead by a blue-green and green alga. Canadian Journal of Microbiology, v.26, n.11, p.1300-1311, 1980.

LEE, L.H.; LUSTIGMAN, B.; CHU, I-YU; JOU, HUEY-LING. Effect of aluminum and $\mathrm{pH}$ on growth of Anacystis nidulans. Bulletin of Environmental Contamination and Toxicology, v.46, n.5, p.720-726, 1991.

MAQUIEIRA, A.; ELMAHADI, H.A.M.; PUCHADES, R. Immobilized cyanobacteria for on-line trace metal enrichment by flow injection atomic absorption spectrometry. Analytical Chemistry, v.66, n.21, p.3632-3638, 1994.

McKAY, R.M.L.; GIBBS, S.P.; ESPIE, G.S. Effect of dissolved inorganic carbon on the expression of carboxysomes, localization of rubisco and the mode of inorganic carbon transport in cells of the cyanobacterium Synechococcus UTEX-625. Archives of Microbiology, v.159, n.1, p.21-29, 1993.

MORI, T.; BINDER, B.; JOHNSON, C.H. Circadian gating of cell division in cyanobacteria growing with average doubling times of less than 24 hours. Proceedings of National Academy of Science of the USA, v.93, n.19, p.10183-10188, 1996.

NAKAMURA, Y.; KANEKO, T.; SATO, S.; IKEUCHI, M. Complete genome structure of the thermophilic cyanobacterium Thermosynechococcus elongatus BP-1. DNA Research, v.9, n.4, p.123-130, 2002. 
NEILAN, B.A.; JACOBS, D.; GOODMAN, A.E. Genetic diversity and phylogeny of toxic cyanobacteria determined by DNA polymorphisms within the phycocyanin locus. Applied and Environmental Microbiology, v.61, n.11, p.3875-3883, 1995.

NELSON, D.L.; COX, M.M. Carbohydrate biosynthesis. In: NELSON, D.L.; COX, M.M. Lehninger principles of biochemistry. New York: Worth Publishers, 2000. cap.20, p.722-769.

NIES, D.H. Efflux-mediated heavy metal resistance in prokaryotes. FEMS Microbiology Reviews, v.27, n.2-3, p.313-339, 2003.

ONAI, K.; MORISHITA, M.; KANEKO, T.; TABATA, S.; ISHIURA, M. Natural transformation of the thermophilic cyanobacterium Termosynechococcus elongatus BP-1: a simple and efficient method for gene transfer. Molecular Genetics and Genomics, v.271, n.1, p.50-59, 2004.

ORÚS, M.I.; RODRÍGUEZ-BUEY, M.L.; MARCO, E.; FERNÁNDEZ-VALIENTE, E. Changes in carboxysome structure and grouping and in photosynthetic affinity for inorganic carbon in Anabaena strain PCC 7119 (Cyanophyta) in response to modification of $\mathrm{CO} 2$ and $\mathrm{Na}+$ supply. Plant and Cell Physiology, v.42, n.1, p.46-53, 2001.

PAERL, H.W. Marine plankton. In: WHITTON, B.A.; POTTS, M. The ecology of cyanobacteria: their diversity in time an space. Dordrecht: Kluwer Academic Publishers, 2000. cap.5, p.121-148. 
PEÑA, M.M.O.; BULLERJAHN, G.S. The DpsA protein of Synechococcus sp. strain PCC7942 is a DNA-binding hemoprotein. Journal of Biological Chemistry, v.270, n.38, p.22478-22482, 1995.

PIETRINI, F.; IANNELLI, M.A.; PASQUALINI, S.; MASSACCI, A. Interaction of cadmium with glutathione and photosynthesis in developing leaves and chloroplasts of Phragmites australis (cav.) trin. ex steudel. Plant Physiology, v.133, n.2, p.829-837, 2003.

RACHLIN, J.W.; JENSEN, T.E.; WARKENTINE, B. The toxicological response of the alga Anabaena -flos-aquae (Cyanophyceae) to cadmium. Archives of Environmental Contamination and Toxicology, v.13, n.2, p.143-151, 1984.

RANGSAYATORN, N.; UPATHAM, E.S.; KRUATRACHUE, M.; POKETHITIYOOK, P.; LANZA, G.R. Phytoremediation potential of Spirulina (Arthrospira) platensis: biosorption and toxicity studies of cadmium. Environmental Pollution, v.119, n.1, p.45-53, 2002.

ROBERTSON, B.R.; TEZUKA, N.; WATANABE, M.M. Phylogenetic analyses of Synechococcus strains (cyanobacteria) using sequences of 16S rDNA and part of the phycocyanin operon reveal multiple evolutionary lines and reflect phycobilin content. International Journal of Systematic and Evolutionary Microbiology, v.51, p.861-871, 2001.

ROBINSON, N.J.; GUPTA, A.; FORDHAM-SKELTON, A.P.; CROY, R.D.R.; WHITTON, B.A.; HUCKLE, J.W. Prokaryotic metallothionein gene characterization and expression: chromosome crawling by ligationmediated PCR. Proceedings of Royal Society, v.242, p.241-247, 1990. 
ROBINSON, N.J.; RUTHERFORD, J.C.; POCOCK, M.R.; CAVET, J.S. Metal metabolism and toxicity: repetitive DNA. In: WHITTON, B.A.; POTTS, M. The ecology of cyanobacteria: their diversity in time an space. Dordrecht: Kluwer Academic Publishers, 2000. cap.16, p.443-463.

ROUCH, D.A.; LEE, B.T.O.; MORBY, A.P. Understanding cellular-responses to toxic agents: a model for mechanism-choice in bacterial metal resistance. Journal of Industrial Microbiology, v.14, n.2, p.132-141, 1995.

ROUILLON, R.; TOCABENS, M.; CARPENTIER, R. A photoelectrochemical cell for detection pollutant-induced effects on the activity of immobilized cyanobacterium Synechococcus sp. PCC 7942. Enzyme and Microbial Technology, v.25, p.230-235, 1999.

SAZUKA, T.; OHARA, O. Towards a proteome project of cyanobacterium Synechocystis sp. strain PCC6803: linking 130 protein spots with their respective genes. Electrophoresis, v.18, n.8, p.1252-1258, 1997.

SAZUKA, T.; YAMAGUCHI, M.; OHARA, O. Cyano2Dbase updated: linkage of 234 protein spots to corresponding genes through $\mathrm{N}$-terminal microsequencing. Electrophoresis, v.20, n.11, p.2160-2171, 1999.

SEN, A.; DWIVEDI, K.; RICE, K.A.; BULLERJAHN, G.S. Growth phase and metal-dependent regulation of the dpsA gene in Synechococcus sp. strain PCC 7942. Archives of Microbiology, v.173, n.5-6, p.352-357, 2000.

SCHÖNHUBER, W.; ZARDA, B.; EIX, S.; RIPPKA, R.; HERDMAN, M.; LUDWIG, W.; AMANN, R. In situ identification of cyanobacteria with horseradish peroxidase-labeled, rRNA-targeted oligonucleotide probes. Applied and Environmental Microbiology, v.65, n.3, p.1259-1267, 1999. 
SCHWARZ, R.; GROSSMAN, A.R. A response regulator of cyanobacteria integrates diverse environmental signals and is critical for survival under extreme conditions. Proceedings of the National Academy of Science of the USA, v.95, n.18, p.11008-11013, 1998.

SIMON, W.J.; HALL, J.J.; SUZUKI, I.; MURATA, N.; SLABAS, A.R. Proteomic study of the soluble proteins from the unicellular cyanobacterium Synechocystis sp. PCC6803 using automated matrix-assisted laser desorption/ionization-time of flight peptide mass fingerprinting. Proteomics, v.2, n.12, p.1735-1742, 2002.

SINGH, S.P.; PANDEY, A.K. Cadmium toxicity in a cyanobacterium: effect of modifying factors. Journal of Environmental and Experimental Botany, v.21, n.2, p.257-265, 1981.

SINGH, S.P.; YADAVA, V. Cadmium induced-inhibition of ammonium and phosphate-uptake in anacystis nidulans: interaction with other divalentcations. Journal of General and Applied Microbiology, v.30, n.2, p.7986, 1984.

STAL, L.J. Cyanobacterial mats and stromatolites. In: WHITTON, B.A.; POTTS, M. The ecology of cyanobacteria: their diversity in time and space. Dordrecht: Kluwer Academic Publishers, 2000. cap.4, p.61-120.

STANIER, R.Y. Position of cyanobacteria in world of phototrophs. Carlsberg Research Communications, v.42, n.2, p.77-98, 1977.

STANIER, R.Y.; COHEN-BAZIRE, G. Phototrophic prokaryotes: the cyanobacteria. Annual Review of Microbiology, v.31, p.225-274, 1977. 
STRATTON, G.W.; CORKE, C.T. The effect of cadmium ion on the growth, photosynthesis, and nitrogenase activity of Anabaena inaequalis. Chemosphere, v.8, n.5, p.277-282, 1979.

THOMPSON, S.L.; MANNING, F.C.R.; MCCOLL, S.M. Comparison of toxicity of chromium III and chromium VI to cyanobacteria. Bulletin of Environmental Contamination and Toxicology, v.69, n.2, p.286-293, 2002.

TILLETT, D.; PARKER, D.L.; NEILAN, B.A. Detection of toxigenicity by a probe for the microcystin synthetase A gene (mcy A) of the cyanobacterial genus Microcystis: comparison of toxicities with 16S rRNA and phycocyanin operon (Phycocyanin Intergenic Spacer) phylogenies. Applied and Environmental Microbiology, v.67, n.6, p.2810-2818, 2001.

VIEIRA, J.M.S.; AZEVEDO, M.T.P.; AZEVEDO, S.M.F.O.; HONDA, R.Y.; CORREA, B. Microcystin production by Radiocystis fernandoi (Chroococcales, Cyanobacteria) isolated from a drinking water reservoir in the city of Belem, PA, Brazilian Amazonian region. Toxicon, v.42, n.7, p.709-713, 2003.

VYMAZAL, J. Toxicity and accumulation of cadmium with respect to algae and cyanobacteria: a review. Toxicity Assessment: an International Quarterly, v.2, p.387-415, 1987.

WANG, Y.; SUN, J.; CHITNIS, P.R. Proteomic study of the peripheral proteins from thylakoid membranes of the cyanobacterium Synechocystis sp. PCC 6803. Electrophoresis, v.21, n.9, p.1746-1754, 2000. 
WEBB, R. The cyanobacterial heat-shock response and the molecular chaperones. In: BRYANT, D.A. The molecular biology of cyanobacteria. Dordrecht: Kluwer Academic Publishers, 1994. cap.26, p.751-767.

WHITTON, B.A. Diversity, ecology, and taxonomy of the cyanobacteria. In: WHITTON, B.A. Photosynthetic prokaryotes. New York: Plenum Press, 1991. cap.1, p.1-7.

WILKINS, J.C.; HOMER, K.A.; BEIGHTON, D. Altered protein expression of Streptococcus oralis cultured at low $\mathrm{pH}$ revealed by two-dimensional gel electrophoresis. Applied Environmental Microbiology, v.67, n.8, p.33963405, 2001.

WILMOTTE, A. Molecular evolution and taxonomy of the cyanobacteria. In: BRYANT, D.A. The molecular biology of cyanobacteria. Dordrecht: Kluwer Academic Publishers, 1994. cap.1, p.1-25.

WILMOTTE, A.M.R.; STAM, W.T. Genetic-relationships among cyanobacterial strains originally designated as Anacystis-nidulans and some other Synechococcus strains. Journal of General Microbiology, v.130, p.27372740, 1984.

XU, B.; TRAWICK, B.; KRUDY, G.A.; PHILLIPS, R.M.; ZHOU, L.; ROSEVEAR, P.R. Probing the metal binding sites of Escherichia coli isoleucyl-tRNA synthetase. Biochemistry, v.33, n.2, p.398-402, 1994.

YBARRA, G.R.; WEBB, R. Effects of divalent metal cations and resistance mechanisms of the cyanobacterium Synechococcus sp. Strain PCC7942. Journal of Hazardous Substance Research, v.2, p.1-9, 1999. 
YOUSEF, N.; PISTORIUS, E.K.; MICHEL, K.P. Comparative analysis of idiA and isiA transcription under iron starvation and oxidative stress in Synechococcus elongatus PCC 7942 wild-type and selected mutants. Archives of Microbiology, v.180, n.3, p.471-483, 2003. 